

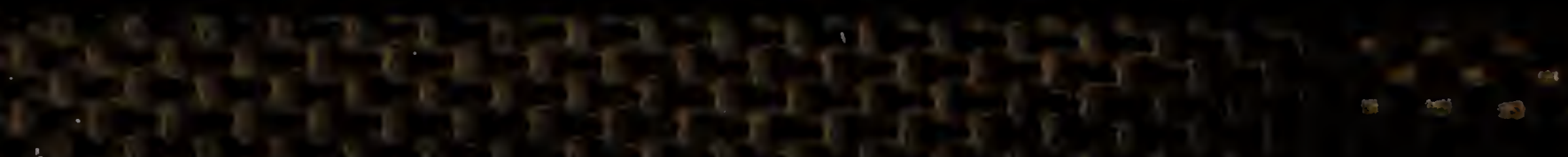

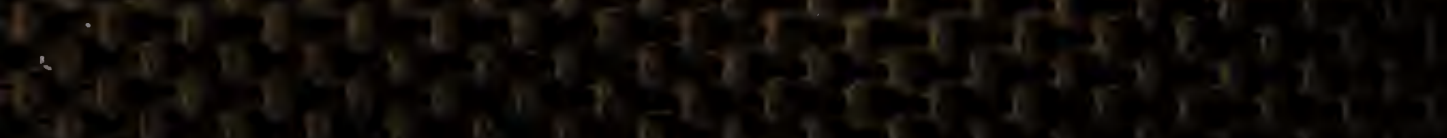

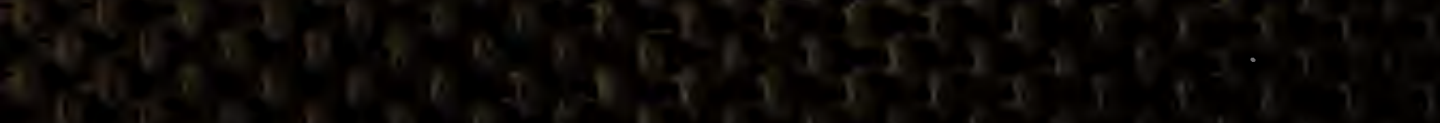

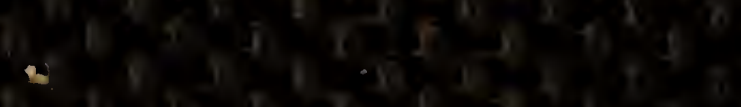

$$
\begin{aligned}
& 7^{-4}+x^{2}
\end{aligned}
$$




\title{
Corn Smut Caused by Ustilago maydis
}

\author{
J. J. Christensen
}

Monograph Number 2

Published by

The American Phytopathological Society

1963

Copies may be purchased from the business manager, The American Phytopathological Society 



\section{Corn Smut Caused by Ustilago maydis \\ J. J. Christensen}

Department of Plant Pathology and Botany

Institute of Agriculture, University of Minnesota, St. Paul

The writer is indebted to N. A. Anderson, C. M. Christensen, C. J. Eide, K. D. Fezer, M. F. Kernkamp, and R. D. Wilcoxson, University of Minnesota, for reading the manuscript and for making constructive suggestions in the preparation of the manuscript. The writer also wishes to acknowledge the efficient assistance of Vivian Schwab.

Paper No. 1119, Miscellaneons Jonrual Series, Mimesota Agricultural Experiment Station. 


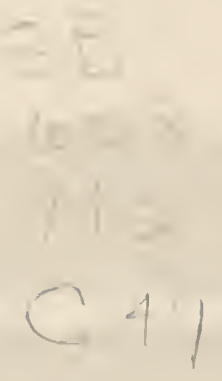

Digitized by the Internet Archive in 2012 with funding from LYRASIS Members and Sloan Foundation 


\section{CONTENTS}

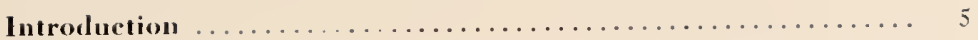

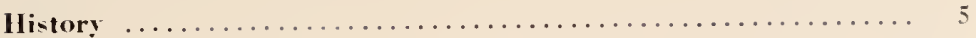

Botanical name .............................. 5

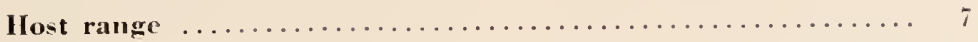

Losses ........................................

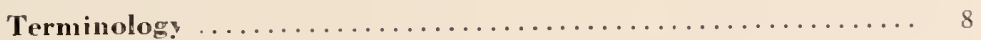

Life history $\ldots \ldots \ldots \ldots \ldots \ldots \ldots \ldots \ldots \ldots \ldots \ldots \ldots \ldots, \quad 9$

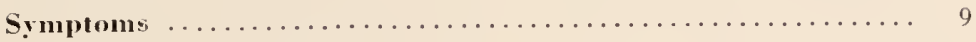

Isolation of $\mathbf{U}$. milydis $\ldots \ldots \ldots \ldots \ldots \ldots \ldots \ldots \ldots \ldots \ldots \ldots \ldots \ldots, 12$

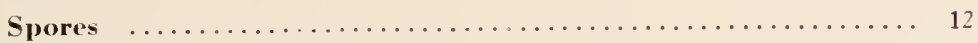

Morphology of spores $\ldots \ldots \ldots \ldots \ldots \ldots \ldots \ldots \ldots \ldots \ldots \ldots \ldots \ldots \ldots \ldots, 12$

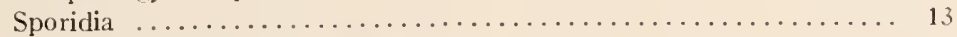

Number of spores and dissemination $\ldots \ldots \ldots \ldots \ldots \ldots \ldots \ldots \ldots \ldots$

Disscmination of spores $\ldots \ldots \ldots \ldots \ldots \ldots \ldots \ldots \ldots \ldots \ldots \ldots \ldots \ldots \ldots \ldots, 13$

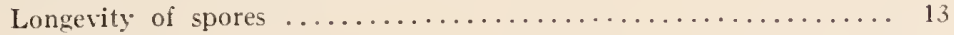

Germination of spores $\ldots \ldots \ldots \ldots \ldots \ldots \ldots \ldots \ldots \ldots \ldots \ldots \ldots \ldots \ldots \ldots, 14$

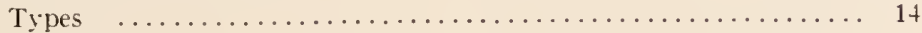

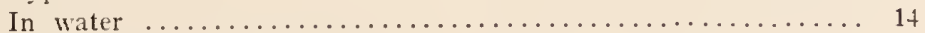

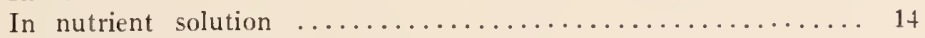

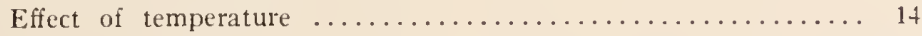

Special stimulants ............................ 15

Methods of inoculation ............................. 15

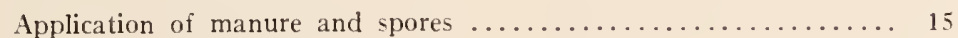

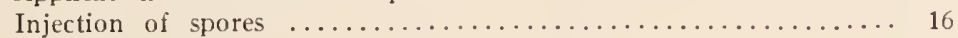

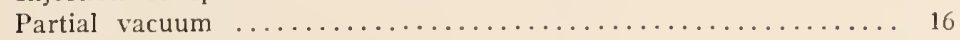

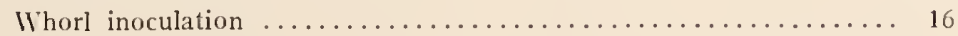

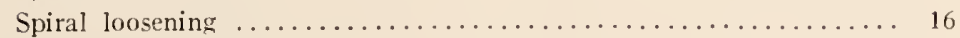

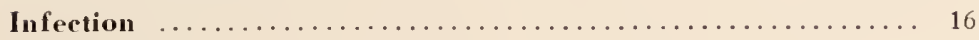

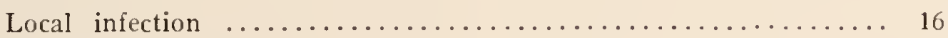

Haploid infection ............................... 17

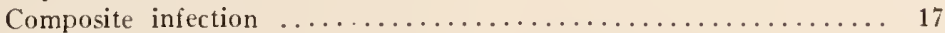

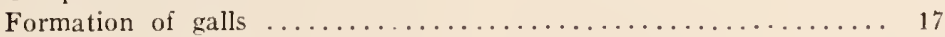

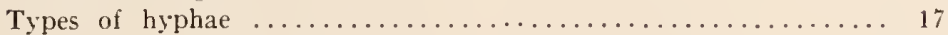

Formation of chlamydospores $\ldots \ldots \ldots \ldots \ldots \ldots \ldots \ldots \ldots, 18$

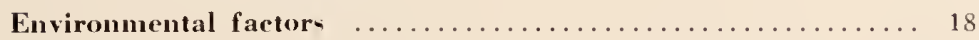

Moisture ................................... 18

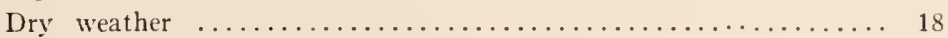

Temperature $\ldots \ldots \ldots \ldots \ldots \ldots \ldots \ldots \ldots \ldots \ldots \ldots \ldots \ldots \ldots \ldots \ldots \ldots \ldots \ldots, 18$

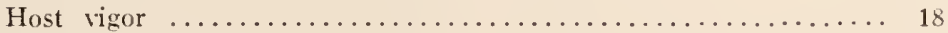

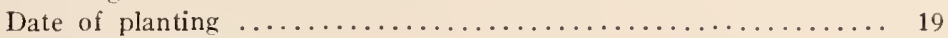

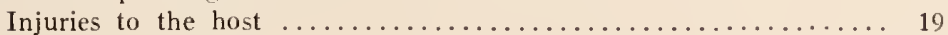

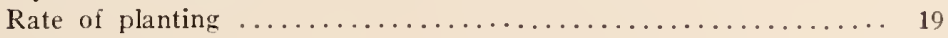

Solopathogens .................................... 19

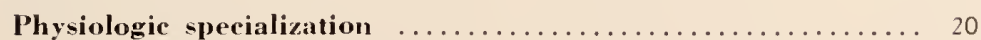

Parasitic differences ................................ 20

Local and nonlocal smut $\ldots \ldots \ldots \ldots \ldots \ldots \ldots \ldots \ldots \ldots \ldots \ldots \ldots \ldots, 21$

Phenotypic variability ........................... 21

Mutation ........................................ 23

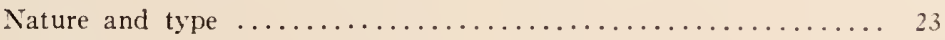

Frequency $\ldots \ldots \ldots \ldots \ldots \ldots \ldots \ldots \ldots \ldots \ldots \ldots \ldots \ldots \ldots \ldots \ldots \ldots \ldots \ldots \ldots \ldots, 24$

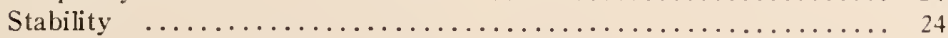

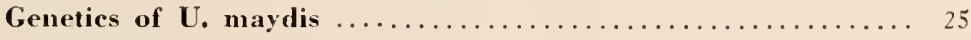

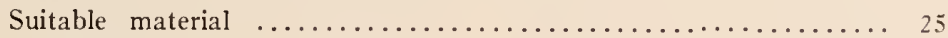

Nuclear behavior in germination ..................... 26

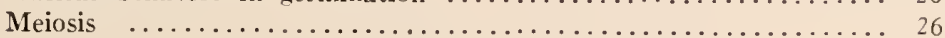


Karyogamy

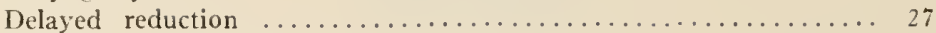

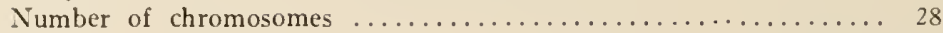

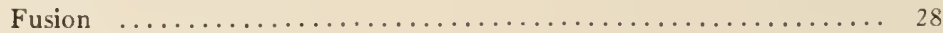

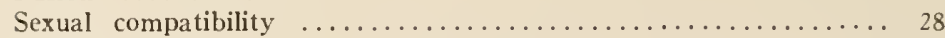

Inheritance of:

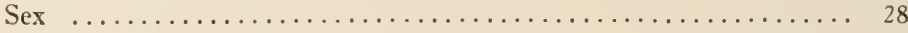

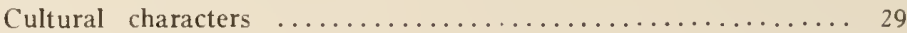

Color .................................... 29

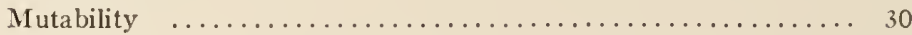

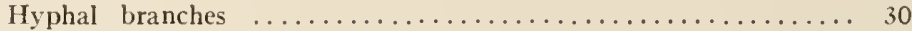

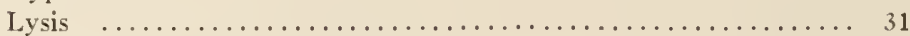

Formation of chlamydospores $\ldots \ldots \ldots \ldots \ldots \ldots \ldots \ldots \ldots \ldots \ldots \ldots \ldots \ldots \ldots \ldots$

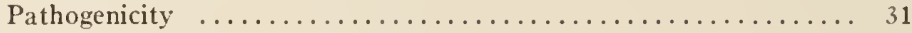

Toxic effect of smmt $\ldots \ldots \ldots \ldots \ldots \ldots \ldots \ldots \ldots \ldots \ldots \ldots \ldots \ldots$

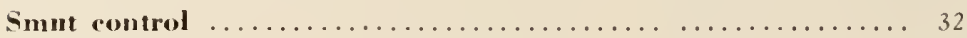

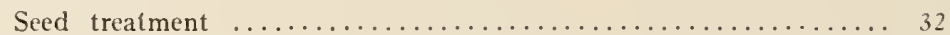

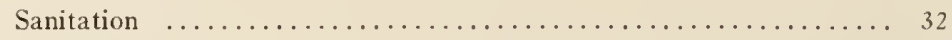

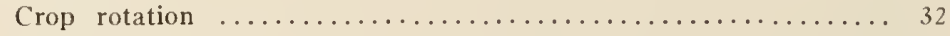

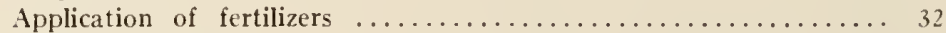

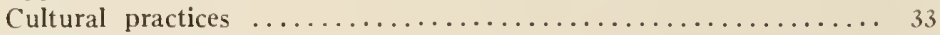

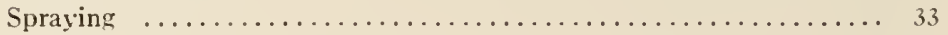

Biological control ........................... 33

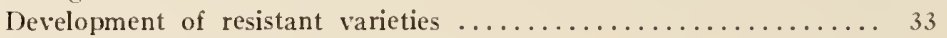

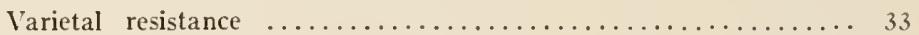

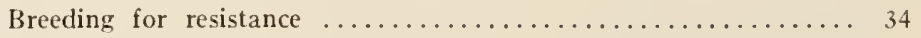

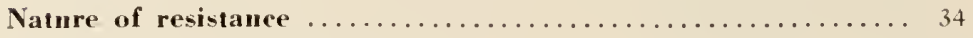

References and bibliography ................. 34

Literature cited and references $\ldots \ldots \ldots \ldots \ldots \ldots \ldots \ldots \ldots \ldots$

\section{Fignres}

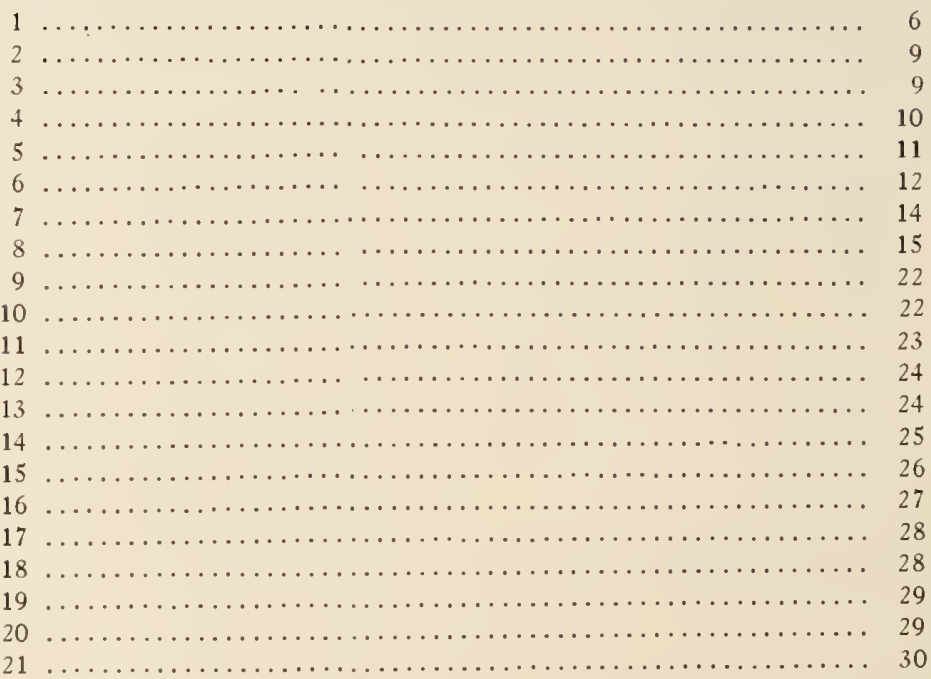


Introduction.-Corn smut, caused by Ustilago maydis (DC.) Cda.. has been of tremendous interest to biologists and to farmers for more than 250 years. Smut galls are often large and conspicuous and corn smut has been a subject of many observations, speculations. and superficial as well as intensive investigations. In spite of the interest which has been maintained for so long, the complete life history of $U$. maydis was not known until 1927 when the sexual stage was discovered. Even now it is not definitely known when, where, and how most of the infection occurs. Therefore, it is not surprising that much of the literature dealing with etiology, ecological relationships. epiphytotics, and practical control contains a rast array of confusing and often contradictory statements.

The fungus is nearly ideal as a tool in basic scientific studies and for elucidating principles of mycology, plant pathology, genetics, and plant physiology. This is indicated by the large number of publications on mutation, inheritance, and physiological studies on the fungus and on the inheritance of resistance to corn smut.

U. maydis is of special genetic interest because it is usually heterothallic or occasionally homothallic and consists of an indefinite number of haploid and diploid biotypes. Further, the organism is not static, but dynamic; new biotypes are constantly arising by hybridization and by mutation in both the haploid and diploid stages; meiosis may occur in both the vegetative and sexual stages. The magnitude of genetic variation is indicated by the fact that in laboratories of the University of Minnesota alone more than 15,000 different biotypes have been isolated and studied (282).

History.-It is generally believed that $U$. maydis was native to the Western Hemisphere and was carried to southern Europe by the early Spanish explorers. Although it was observed in Europe about 1750 , it was not reported from the U.S. until 1822 when Schweinitz published his first list of American fungi (293). According to Arthur and Stuart (5), the earliest European records of the fungus are by the French biologists Bonnet (1754), Aymen (1760), and Tillet (1766).

According to Hitchcock and Norton (143), Aymen reported that all the flowers of the tassel were smutty and that these were the source of the disease. He concluded, therefore, that when a smutty ear also contained sound kernels it had been fertilized by the pollen of a healthy plant.

In 1760-61, Tillet (335) started a detailed investigation of corn smut in fields in Agoumori, a province in southern France. Five years previously in 1755, Tillet had demonstrated conclusively that stinking smut of wheat could be induced by inoculating the seed with Tilletia sp. (see 98). Therefore, he dusted the kernels of corn with chlamydospores of $U$. maydis before planting. but to his great surprise no smut developed. Consequently, he concluded that corn smut was not a contagious disease like stinking smut of wheat, but was caused by an excessive amount of sap which accumulated in certain parts of the plant and then induced excessive dilation of cellular tissue.

During the next 140 years, other attempts were made to induce corn smut galls, but all were unsuccessful
(5. 34, 335). Therefore, it is not surprising that some of the leading biologists for many years accepted and perpetuated the theory that stagnation of sap or excessive sap was the cause of corn smut $(25,339)$. Others attributed the smut galls to fogs, dews, rains, too rich soil, or too much raw manure $(5.335)$. Still others considered the galls spontaneous abnormalities, monstrosities. Bonnet (26) concluded that insects deposited some irritating substance which caused the sap to flow to injured parts thus producing the galls

Corn smut was not recognized as caused by a fungus until about the early part of the nineteenth century even though Beckmann (17) called it a puff ball and named it Lycoperdon zeae in 1768. In 1836, Unger (339) recognized it as a fungus and named it $U$. zeae; but just 3 years previously, in 1833 , he stated that a young smut gall contained nothing but large cells filled with raw sap.

Bonafous (25), in 1836, also considered the smut a plant and recorded some interesting accounts of inoculation experiments (Fig. 1). He stated that BayleBarelle at the botanical garden in Pavia, Italy, obtained no smut when the powder from tumors was used to inoculate seed or the medullary body of stalks, nodes, roots, and parenchyma of leaves. Apparently, the host tissue was injured considerably in these tests because when the spores were introduced into vigorous stalks, without breaking the epidermis, smutty plants were produced. Bonafous could not confirm these results.

Beginning about 1850, de Bary (10), Tulasne and Tulasne (337), Meyen (225), Wolff (364), Fischer von Waldheim (99), Kühn (190), and others attributed the smut galls to fungus infection, but failed to prove it. It was not until $1883-95$ that Brefeld $(34,35,36)$ demonstrated beyond doubt the infective nature of $U$. maydis. He, too, failed to get infection by inoculation of seed; but induced infection by spraying the corn plant with a suspension of sporidia and by dropping sporidial suspensions into the spiral whorl of the corn plant. Brefeld (34) also proved that any young meristematic tissue above the ground was subject to infection. Previously, he had demonstrated for the first time (35) that the corn smut fungus could be propagated indefinitely on nutrient substrates, including manure decoction.

Bessey (20) in Nebraska. Hitchcock and Norton (143) in Kansas, Arthur and Stuart (5) in Indiana. Clinton (60) in Illinois, and Bessey (19) and Pammel (246) in Iowa were among early workers in the U.S. to make noteworthy contributions to our knowledge of corn smut. At the end of the nineteenth century numerous semipopular publications appeared on losses. control practices, and on toxicity of smuts to animals. The more recent publications dealt mostly with basic studies on the ecology, physiology, and genetics of $L^{\prime}$. maydis and on the inheritance of resistance of corn to smut $(55,145,158,267,283,314,317)$.

Botanical Name.-Considerable diversity exists in the literature in the use of botanical names for the common corn smut fungus. Beckmann (17), in 1768 . called it Lycoperdon zeae because the smut spores resembled those of a puff ball. Next. the smut fungus was placed in the form genus Uredo or Caeoma along with the rusts. 


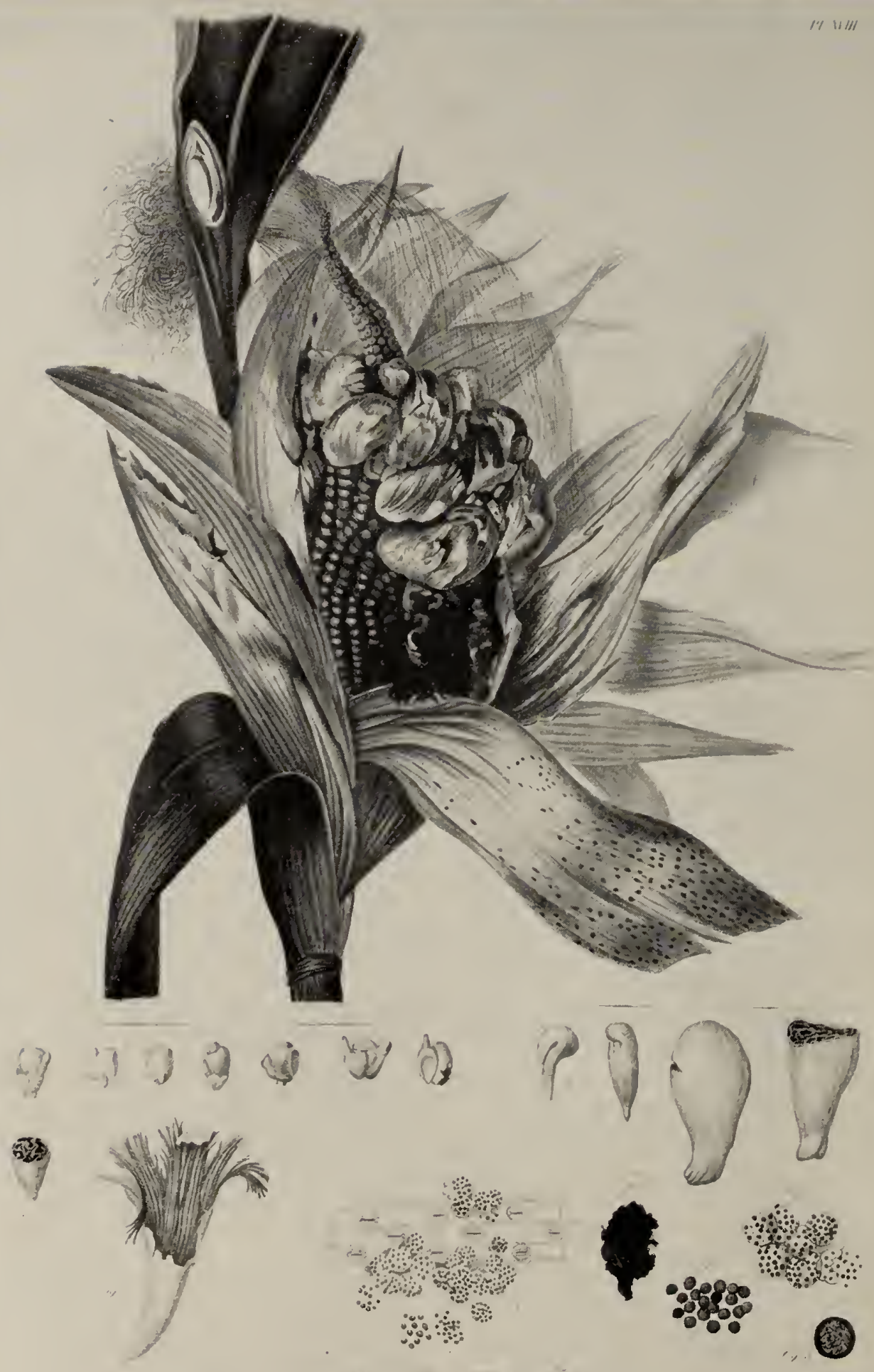


Fig. 1. Reproduction ef the color plate XVIII of corn smut by Bonafous in 1836 (25). A translation of Bonafous' legend to this plate (objects from left to right) follows: Fig. 1. Ear with many kernels which have become monstrous and deformed by the effect of the smut. Fig. 2. No. 1, 2, 3, 4, 5, 6, 7. Different kernels of corn still recognizable and variously affected by smut: we see that they can be attached from above, frcm below, from the sides, and in many places at the same time. Fig. 3. No. 8, 9, 10, 11. Here, the kernels of corn have entirely lost their form; and the progress of the smut, by increasing their volume and by deforming them, has transformed them into hollow bodies filled with fibers and black powdery grains; No. 11 which is a horizontal section, shows the interior aspect of one of these bodies which has become monstrous. Fig. 4. Another section showing the same interior aspect. Fig. 5. Here, a smutted kernel is beginning to decompose. It is remarkable that the smut is able to produce an appearance of fibrous tissue in a corn kernel which, in its normal state, only has a cellular tissue. Fig. 6. A small mass of decomposed cellular tissue from a monstrously developed kernel whose elementary body or globulin, according to $M$. turpins system, has increased in volume and passed from a white color to a brown color. Fig. 7. Sometimes, a few of the vesicles in which the altered globulin is distinguished are still found (a) a ruptured vesicle with escaping globulins. Fig. 8. A smutted globulin, enlarged. Fig. 9. A vesicular globule still more enlarged, in the interior of which we see some very fine granulations, with a more opaque circle which indicates the thickness of the vesicle. Fig. 10. A portion of tissue taken in a healthy leaf and in which we find in (a) the epidermis or cuticle, transparent and colorless membrane; (b) a very elegant netwerk composed of a filament arranged in a zig-zag; (c) stomata; (d) vesicles containing an abundant, green globulin which is capable of altering itself and of converting itself into the black dust of the smut; (e) a ruptured vesicle with the escaping globulin. The two envelopes of the kernel, in becoming monstrous and in taking a sac-like development also give rise to a black smutted globulin. The diameter of the smutted globulin is $1 / 200$ of a millimeter. Like all the diseased globulin, these globules are remarkable by the uniformity of their size. (Transl. by Claude C. Rernier.)

In 1836. Unger (340) recognized it as a fungus and named it Ustilago zeae. Until recent years, this name was used most extensively by most investigators. In 1944. Stevenson and Johnson (326) stated that $U$. maydis (DC.) Cda. is the correct binomial, according to the International Rules of Botanical Nomenclature. This binomial is currently used by most plant pathologists (98).

The synonyms for $U$. maydis were taken primarily from publications by Clinton (61), Fischer (96), and Stakman (305).

Synonymy.-Ustilago maydis (DC.) Cda.. Icones

Fung. 5:3. 18+2.

Ustilago carbo-maydis Phillipar., Traite Caris Charbon 68. 1837.

Ustilago maydis Lev., Ann. Sci. Nat. II. 11:13. 1839.

Lycoperdon zeae Beckm., Hannov. Mag. 6:1330. 1768.

Uredo segetum var. mays-zeae DC.. Fl. Fr. 2:596. 1805.

Uredo zeae-mays DC., Syn. Pl. Fl. Gall., p. 47. 1806.

Uredo segetum f. zeae-maydis DC., Encycl. Neth.

Botan. 8:229. 1808.

Uredo maydis DC., FI. Fr. 6:77. 1815.

Uredo zeae Schw., Schr. Nat. Ges. Leipzig 1:71. 1822.

Caeoma zeae Link., Sp. Plant. 2:2. 1824.

Erysibe maydis (DC.) Wallr., Fl. Crypt. Germaniae $2: 215.1883$.

Ustilago zeae (Schw.) Ung., Einfl. Bodens, p. 211. 1836.

Ustilago schweinitzii Tul., Ann. Sci. Natl. Botan. 7:86. 1847.

U'stilago zeae-mays Wint., Rabh. Krypt. Fl. 1:97. 1881.

L stilago euchlaenae Archang., Erb. Critt. Ital. 2:1152. 1882.

Ustilago maydis (DC.) Cda.f. foliicole Sacc. Mycol. Ital. 1269. 1886.

Ustilago maydis f. androphila D. Sacc., Mycol. Ital. 1270. 1886.

Host Range.-As far as is known, $U$. maydis attacks only 2 species of plants: Indian corn (Zea mays L.) and teosinte (Euchlaena mexicana Schrad.).

Losses.-Corn smut caused by $U$. maydis is virtually world-wide in distribution. It may be found wherever corn is cultivated. except in Australia. About 50 years ago, $U$. maydis was introduced into Australia, but it has been eradicated (207). Apparently, corn smut is most destructive in the U.S. where it often causes severe losses (78, 160, 170,341, 351).

A survey of literature indicates that there have been marked fluctuations in the prevalence and economic importance of corn smut in the U.S. Unfortunately, in many cases, only the prevalence of smut is given and not the losses caused by it; this is especially true of the early reports.

The economic importance of corn smut was not fully recognized until the latter part of the nineteenth century. Losses in Wisconsin in 1881 were given as $5-15 \%$ for individual fields (132). In 1884. Bessey (19) indicated that corn smut losses in Iowa were about $2 \%$ of the crop. He reported the loss for 1 field of sweet corn at $66 \%$. In 1897, Selby and Hickman (298) reported fields in Ohio that contained $25-45 \%$ smutinfected plants and indicated the loss to be about $4.4 \%$ of the crop. Clinton (60), in 1900, estimated the loss in Illinois at $0.5-5.0 \%$. The average annual loss in Illinois between 1917 and 1937 is given as $2.3 \%$ (341).

In 1896, Hitchcock and Norton (143) estimated the average corn smut infection in Kansas at $6 \%$. Twentynine years later. Potter and Melchers (267) reported that fields in eastern Kansas with $30-50 \%$ smut-infected plants were not uncommon and that fields with 60$80 \%$ infected plants were common in semiarid regions of Kansas. It was their opinion that smut infection had become much more prevalent during the decades between 1900 and 1930 than it was previously. Until the development of resistant or semiresistant hybrids, fields of open-pollinated corn with $25-50 \%$ infection were not uncommon $(78,80,158,328)$. In Minnesota, some fields occasionally had more than $70 \%_{c}$ smutty plants. Today, although more than 700 hybrid varieties are grown in Minnesota, one seldom encounters fields with more than 5 or $10 \%$ infection, usually much less. Smut is still a destructive disease on sweet corn. It not only reduces yield, but adds to difficulties and cost in processing of sweet corn.

From 1918 through 1924, the annual loss in yield from corn smut in the U.S. was about $2.1 \%$ (341). During the 1920 's, smut losses ranging from 5 to $10^{\circ} \mathrm{c}$ 
were frequently reported from individual states (3+1). Until about 1940, losses in Minnesota ranged from 3 to $10 \%$ annually. Now, it is perhaps less than $1 \%$ for field corn in Minnesota, but much more for sweet corn and similar losses also occur elsewhere in the U.S. $(78,109)$.

In general, most estimates of smut losses have been based on plainly visible infection. Less conspicuous galls are frequently overlooked, although they may often reduce yield of corn materially, especially if multiple galls occur on the same plant $(161,170)$. Therefore, many of the figures presented here and in early publications are most likely underestimates of the actual losses incurred. It is relatively easy to approximate smut losses when seedlings are killed or when stalks are so severely infected that ears are almost destroyed. but not when the smut galls are small and more or less hidden.

A number of investigators $(160,161,170,176)$ have found that yield of ear corn from infected plants varied with the number, size, and location of the galls. On the average, a single gall reduced ear yield about $25 \%$. Nultiple galls on the main stalk, including the neck (peduncle), usually were more destructive than galls of similar size and number located on shoots and suckers $(161,170)$. A medium or large gall and multiple small galls located on a main stalk frequently caused the plant to be barren $(57,105,161,176,328)$, whereas galls on shoots and suckers seldom did. Small galls on the ear or tassel seldom reduced ear yield significantly whereas large galls at the same locations usually caused barren stalks or severe reduction in ear yield.

Some losses from smut infection may be indirect. Ears produced from smutty plants usually have a poorer luster and lower quality than those from smutfree stalks (170, 328). Michaelson (227) found that plants infected with $U$. maydis were more subject to stalk rot caused by Diplodia zeae (Schw.) Lev. and Gibberella zeae (Schw.) Petch. than smut-free plants and that ears of smutted plants were more likely to be invaded with ear-rotting fungi than those from smutfree plants.

Terminology.- In 1847, the Tulasnes (337) called the germ tube of the chlamydospore a "promycelium." The primary, asexual spores borne on the promycelium were designated as "sporidia," but sometimes they also were referred to as "basidiospores." Brefeld (36) called them "conidia" because they were able to bud like yeast. Because of long and common usage, the term sporidia is the one preferred today by most workers.

The reduction division and segregation of factors normally occur in the promycelium. Therefore, sporidia are often spoken of as "segregates" (314). They are really haploid and gametic in nature and are not exactly comparable to segregates in higher plants. Occasionally, meiosis does not occur; then, the sporidia are diploid. These diploid lines. which can cause infection when injected singly into corn plants, are designated as "solopathogens" (54).

The parasitic stage is usually a "dicaryon," i.e., the 2 compatible nuclei of opposite sex are associated together in a cell. Although the dicaryon behaves genetically like an $F_{1}$ hybrid, the nuclei are not fused; hence, it is a plasma-hybrid and not a zygote (55). The zygote is actually restricted to the chlamydospore. In a few cases, the terms "inbreeding" and "outbreeding" have been used. By "inbreeding" is meant the mating of sporidia from the same promycelium. By "outbreeding" is meant the mating of sporidia from different promycelia (55). This usage may not be exactly comparable to that used for higher plants and animals, but indicates more clearly than any other terms what actually has been done.

The term chlamydospore deserves special consideration because it has been used and defined differently by mycologists and pathologists. The usage of chlamydospores in smut fungi is a well-established term and has come to have definite meaning to scientists in different fields of smut investigations $(85,106,282$, $317,333,361$ ). Most writers on smuts from about 1900 to the present day use the term chlamydospore. During this period, however, various other names have been given to the smut spores produced in sori and galls. These names are "gemmae," "resting spore," "brandspore," and "teleutospore" (now "teliospore").

According to Fischer and Holton (98), the use of the term "chlamydospore" is fundamentally incorrect because a chlamydospore is supposed to be an asexual spore. This statement is questionable because certain smuts produce sori or galls that contain both diploid and haploid chlamydospores (146). In fact, Rowell (280) obtained galls of $U$. maydis that consisted entirely of haploid, asexually produced chlamydospores that were morphologically identical to true diploid chlamydospores of this species. In $U$. ischaemi Fckl., also, apparently no nuclear fusion occurs (312).

In nature, it is not uncommon for chlamydospores of $U$. maydis and also of $U$. avenae (Pers.) Rostr. to germinate directly and cause infection without the formation of promycelia and sporidia $(350,354)$; and thus germinate like chlamydospores of other fungi. Further, similar types of germination may well occur in other smut fungi. Moreover, the nuclear condition of so-called chlamydospores that are produced in culture may be either haploid or diploid; and it is possible that some are even dicaryotic. Surely these are not teliospores!

Finally, the terms chlamydospore and teliospore were used long before their sexual function was ascertained. These 2 terms were derived primarily on the basis of spore formation. Even today, this is used as a criterion for separating the rusts from smuts (1). Further, no one has made a thorough study of nuclear conditions or method of germination of chlamydospores in the other fungi and the need for such a study should be apparent.

Because of the confusion that exists in regard to the nuclear condition in chlamydospores and because of the well-established usage of the term chlamydospore in the smuts, the writer prefers to retain the usage of chlamydospore in this paper. If a change in name is really desirable, however, then the older name "brandspore" which is still in common use in Europe, including Great Britain, would be a more appropriate one than teliospore (144). "Brandspore" has the flawless attributes of meaning a smut spore and implying 


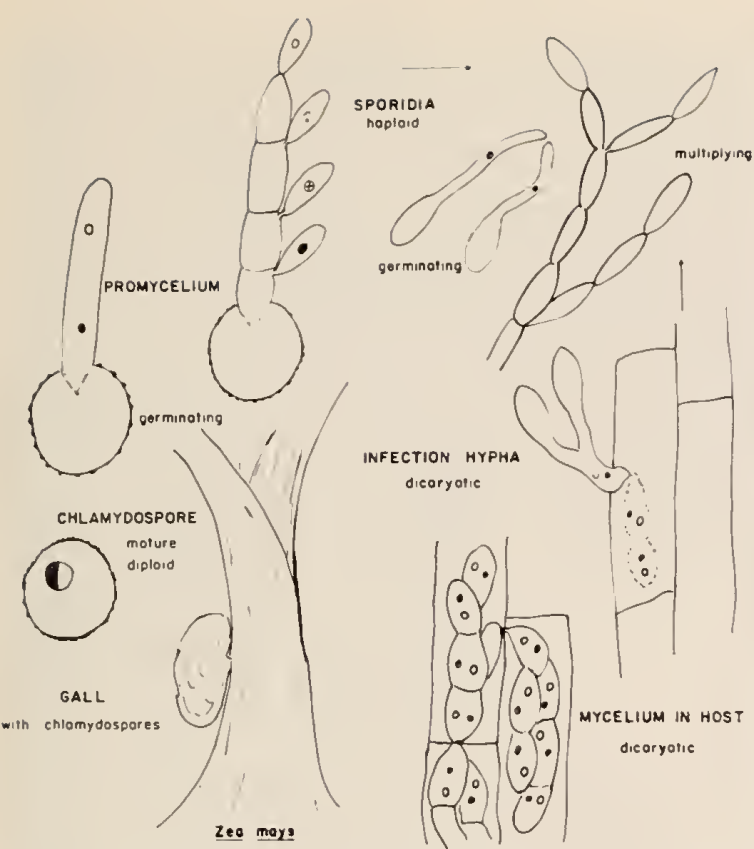

Fig. 2. Diagram illustrating the life cycle of Ustilago maydis. There are many types of deviation from the one given, especially in germination of chlamydospores and meiosis (loy C. Mi. Christensen).

nothing about nuclear condition, mode of formation, nature of germination, or function in the life cycle.

The smutty overgrowth produced by $U$. maydis on corn (Z. mays L.) and teosinte (E. mexicana Schrad.) has been called by several common names: boil, blister, excrescence, gall, pustule tumor, sorus, and swelling. Until about 1900, the term pustule was not uncommon in the U.S.A. and blister is still commonly used in certain European countries (237). Although boil is still used frequently, the term gall is used most commonly, particularly in the U.S.A.

Life History.-The life cycle of $U$. maydis is completed in most cases every time it passes through the host. Three distinct nuclear phases occur in the life history of $U$. maydis: the diplophase, haplophase, and dicaryophase. This involves karyogamy, meiosis, and plasmogamy. Consequently, a collection of chlamydospores does not represent a pure breeding population. The diploid stage is normally restricted to the mature chlamydospore and ends when the spore germinates (Fig. 2).

Chlamydospores are produced in rast numbers in smut galls on corn and teosinte. The spores overwinter on the ground, especially in galls and in plant parts. The smut galls are more or less repellent to water; therefore, the chlamydospores may appear perfectly dry in the spring although the gall may be lying on wet ground. Of course, this may not necessarily occur in moist and humid regions. The galls, at least the greater portion of them, persist until the crop is harvested. Some galls are broken off by mechanical means and fall to the ground; and chlamydospores may be washed off by rain, scattered by farm machinery; perhaps by insects, and readily by wind.

Lsually, the diploid chlamydospore germinates by the formation of a promycelium on which haploid

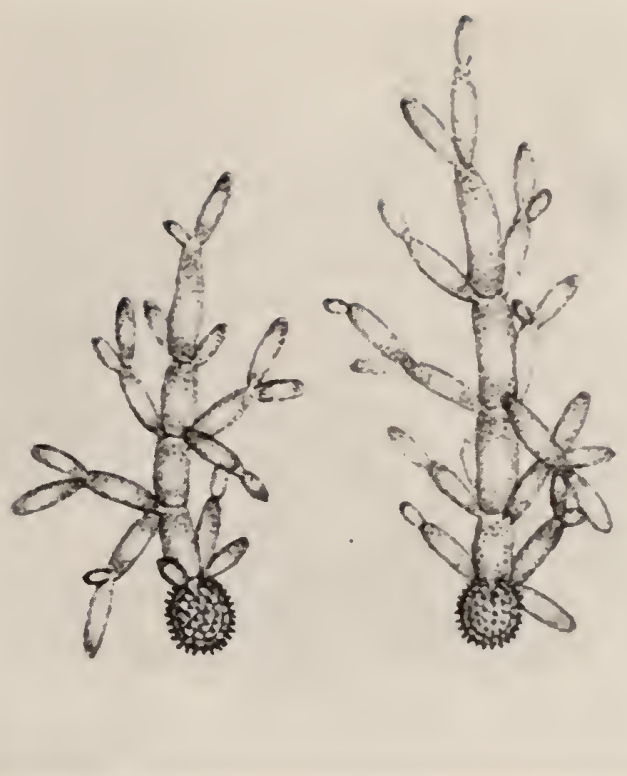

Fig. 3. Germinating chlamydospores of Ustilago maydis producing secondary sporidia in nutrient media (Brefeld, 34).

sporidia are borne (Fig. 3). The sporidia germinate and can be readily propagated on artificial substrates and also in the moisture that collects in axils and in whorls of corn leaves. U. maydis is heterothallic; the parasitic stage. which is the dicaryophase, is initiated by the fusion of sporidia or mycelia of opposite sexes, usually in the host. Chlamydospores also may give rise directly to germ tubes. The germ tube penetrates only the tender tissues and infection is termed local.

In the host, the dicaryophase usually persists until the formation of chlamydospores. When young developing galls are subjected to very high humidities, however, the dicaryotic mycelium in the host may give rise to chains of aerial haploid sporidia; and, if the vegetative mycelium is diploid, the sporidia are diploid. These chains of aerial sporidia are readily disseminated by air currents and driving rains and also may be an important source of inoculum. In culture, dicaryons do not persist because the nuclei usually dissociate, resulting again in the original haploid lines. M. B. Moore (unpublished data, University of Minnesota) apparently isolated dicaryotic hyphae from a living corn plant. At least the hyphae he isolated were stout, contorted, and grew slowly on potato-dextrose agar.

Sysiptous.- $L$. maydis may produce several morphological changes in plants of corn and teosinte. Smut galls are semifleshy, consisting of the smut fungus intermixed with enlarged cells of the affected organs of the host. Young galls are at first firm and light in color and covered with semiglossy peridium which turns black as the gall matures. When the membrane dies, it usually cracks open, exposing the dry pordery spores (Fig. 4).

The mature gall is rather spongy; but sometimes a portion of the gall, or the entire gall. may become firm. 


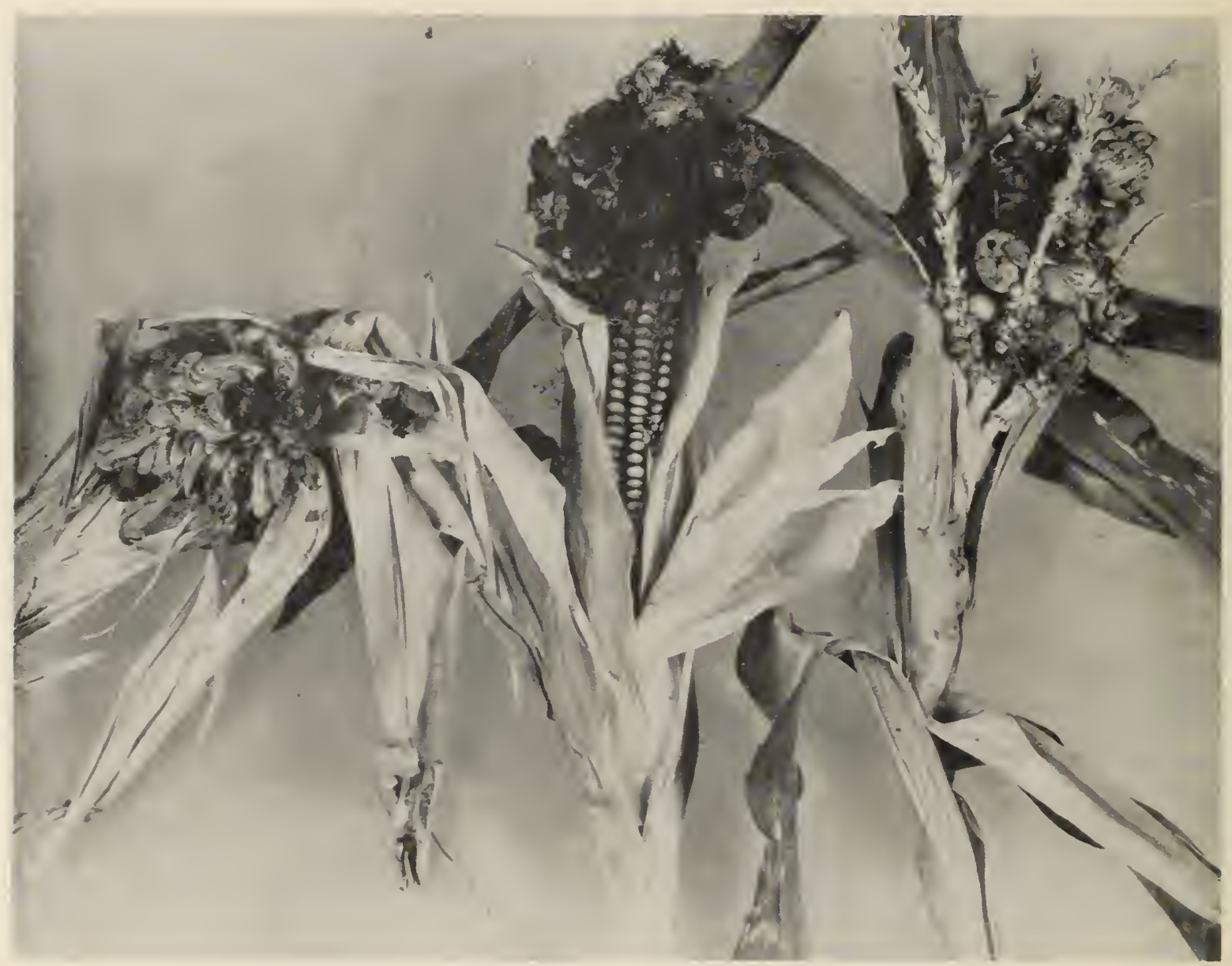

Fig. 4. Ears and tassel of corn affected with smut. Lstilago maydis (Stakman, 310).

apparently because of infection by bacteria and certain fungi. Further. species of Rhizopus, Mucor, Aspergillus. Penicillium, and other genera are not uncommon in corn smut galls.

Smut galls may develop on any part of the plant above ground. wherever the pathogen encounters meristematic tissue. Galls are usually most prevalent on ears, tassels. stems, and nodal shoots. On certain varieties. leaf infection is also very common. especially on or near the midrib. at the junction of the leafsheath and the blade. Galls may occasionally occur on brace roots. but they have never been reported on underground roots.

The galls vary from minute sizes to several $\mathrm{cm}$ diam. occasionally reaching the size of a man's head. The size, the shape, and the degree of proliferation depend to a considerable extent on the location of the gall on the plant and the susceptibility of the host and also on the virulence of the culture of smut (Fig. 5).

Leaf galls differ greatly in size and texture. The large ones occur most frequently on the leaf sheath. while on the blade they are most numerous. Although the calls on the blade are usually small. they may bs large and extend many $\mathrm{cm}$ along the midrib. sometimes more than half the length of the leaf. Many of the very small leaf galls remain firm and frequently contain few. if any. spores. Adjacent tissue often becomes chlorotic and develops anthocyanin. the extent depend- ing on the race of smut and on the variety or line of corn $(54,59,311)$.

The smut galls on the main stalk occur most conmonly just above the nodes. but they may arise on any portion of the stalk. Although galls located on the stalks may be rather large. $20-30 \mathrm{~cm}$ diam. they are usually attached to stems for only a relatively short distance, $2-5 \mathrm{~cm}$. They vary greatly in size and shape; sometimes, they are distinctly lobed or convoluted.

At every node of the stem. there is the bud of a potential shoot (ear). These frequently become infected and often give the appearance that infection actually arose from the stem. Sometimes. on certain varieties. these shoot-galls are completely enclosed by the leaf sheath and may then only be observed by stripping back the leaves.

In the ears, the ovaries and glumes are normally smutted as is the husk sometimes; but apparently, the cob proper and the silk are seldom. if ever. involved. Sometimes, the entire pistillate inflorescence may be converted into a huge smut gall. The husks in many cases are pushed apart or broken through, exposing the black smut mass (Fig. 1. 4).

When tassel flowers are smutted, usually each floral organ forms a small gall and the tassel retains its shape. Sometimes. virtually the whole tassel and stalk below the tassel are converted into a large mass of smut. When the first joint below the tassel "neck" 


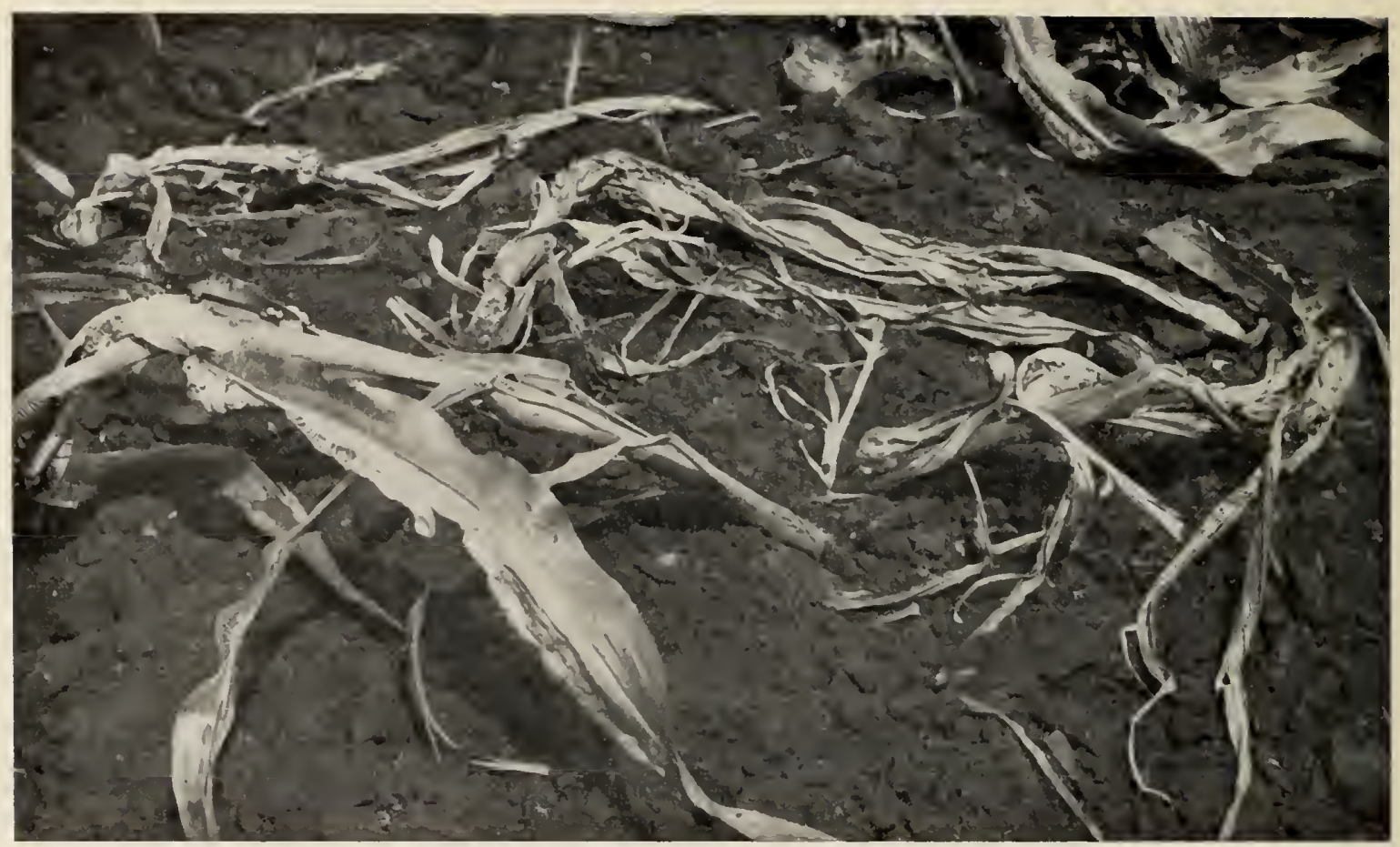

Fig. 6. Young corn plants severely injured by Ustilago maydis and prostrate cn the ground, hence subject to rapid disintegration (Stakman and Christensen, 311 ).

the same whether inoculated with local or nonlocal smut collections; hence, physiologic races do not appear responsible (57). There is some evidence that certain morphological characters, i.e., lack of ligules and tightness of husk, may be involved in some cases $(157,193)$.

IsOLATION of U. MAYDIS.-Cultures can readily be obtained by streaking chlamydospores on $1-2 \%$ potatodextrose agar or any other solid nutrient agar favorable to the growth of the fungus. If the smut gall is infested with other microorganisms, it is desirable to soak the chlamydospores for $20-50 \mathrm{hr}$ in $1 \%$ copper sulfate before plating them on nutrient agar.

The method of isolating single chlamydospores or sets of sporidia is simple and relatively easy with a micromanipulator $(55,79,122)$. A good method is as follows: a thin flat film of clear nutrient medium containing $2 \%$ agar is placed on the surface of a coverglass. With a dry glass needle attached to a micromanipulator, a chlamydospore is picked up from another dry cover-glass previously dusted with dry chlamydospores. Then, the spore is transferred to a marked spot on the agar film. This cover-glass is inverted over a V'an Tiegham cell in a moist chamber such as a petri plate.

After the chlamydospore germinates, the sporidia can be isolated directly from the promycelium or an individual sporidium can be drawn away from the promycelium, along the surface of the agar, until it is some distance from the promycelium and other sporidia. The needle then is pushed into the agar a couple of times to create a slight depression in which the sporidium might bud: and, also, to mark the location of the sporidium (55). The isolated sporidium is allowed to bud for 24-36 hr, depending on the kind of medium; the temperature; and, to some extent, on the rapidity of growth of the particular line of smut. From these small colonies, sporidia are easily removed with the needle of a micromanipulator to another sterile drop of agar. From the colonies produced on the new sets of coverglasses, transfers can usually be made to agar slants within about 2 days. If the original isolated sporidia are properly spaced on the agar films, they can be transferred directly to agar slants (55). The sporidia are normally numbered according to their position on the promycelium. The sporidium at the tip of the promycelium is usually designated no. 1 and the one nearest the spore, no. 4.

When a large population of subcultures is desired, a suspension of sporidia is sprayed or sown on the dry surface of nutrient agar plates. The excess liquid can be removed and kept off by using a clay drying cover. This keeps the small colonies from flowing together during multiplication of the sporidia (203).

In order to reisolate sporidia from mycelium in the host, the following procedure is suggested. Four- 6 days after inoculation, leaves of corn plants on which there is evidence of good infection, are cut off and disinfected. They are dipped in $70 \%$ alcohol, immersed in mercuric bichloride, 1:1.000 for 2-3 min, dipped in alcohol again, then rinsed in sterile distilled water or, better still. in 1 or $2 \%$ solution of sodium hypochlorite. Following this treatment, the leaves are incubated in a sterile moist chamber. It usually requires 3-4 days for aerial sporidia to develop on the infected parts. The individual sporidia can be isolated in the usual manner.

SPOREs.-Morphology of spores.-U. maydis is a good example of the wide diversity that can exist in the size and shape of spores within a smut species and illustrates the need for an adequate sample of spores in 
describing the range within a species. Clinton (61) described the chlamydospores of $U$. maydis as ellipsoidal to spherical, more or less irregular, prominently but rather bluntly echinulated, and usually 8-11 occasionally up to $15 \|$ long. Fischer (97) considers the spore mostly globose to sub-globose, light olive brown, and chiefly 7-10 $\mu$ diam.

Christensen (55) gave the average size of 700 chlamydospores taken from 7 sources as $8.2 \mu \pm 0.2$ $\mathrm{x} 9.0 \pm 0.2 \mu$. The length varied, however, from $4.8 \mu$ to $30.7 \mu$. Chlamydospores produced by different isolates differed in average size from $7.8 \mu \times 8.5 \mu$ to $9.1 \mu \times 10 \mu$.

Chilton (52) measured 100 chlamydospores from each of 21 crosses and recorded big differences in size of chlamydospores. He found an association between abnormally large chlamydospores and their tendency to germinate abnormally, i.e., by promycelia that were distorted and often autolyzed. The width and length of the abnormally germinating chlamydospores varied from $9.1 \mu \times 9.7 \mu$ to $8.1 \mu \times 11.7 \mu$; those from normally germinating spores, from $7.4 \mu \times 7.9 \mu$ to $7.2 \mu \times 8.9 \mu$. On the basis of the above figures, the size of chlamydospores of $U$. maydis may differ by more than $30 \%$.

Chlamydospores taken from very small galls were frequently angular, very irregular, and sometimes bizarre in shape.

Sporidiu.-The length of sporidia differs greatly, especially when the lines are grown on artificial substrates. Christensen (55) measured the sporidia from 3 diploid lines and 4 haploid lines. The average length of sporidia of a given line varied from $13.4 \mu$ to $28.9 \mu$ depending on their source. Although the sporidia of 3 of the 4 haploid lines were shorter than those of the 3 diploid lines, the sporidia of 1 haploid line were longer than 2 of the diploid lines. The size of sporidia was no indication of their nuclear condition (55). The primary sporidia, those produced on the promycelium, were usually regular, hyaline, and fusiform, although these also may differ considerably in size and shape.

Number of spores and dissemination.-U. maydis produces an enormous number of both chlamydospores and sporidia and is undoubtedly the most prolific species of the smut fungi. The number of chlamydospores $\mathrm{cm}^{3}$ of gall tissue has been estimated at 2.5-6 billion $(5,56)$. Thus, in a single smut gall of medium size, there may be more than 200 billion spores. Several galls may occur on a single corn plant. When one considers that there are over 70 million acres of corn in the U.S.A. alone, the number of chlamydospores produced in a single season must be incomprehensibly large, even if only a small percentage of the plants are infected.

The number of sporidia produced also must be very great, for when chlamydospores germinate, the promycelium may give rise to 4 , and often many more, primary sporidia. These, in turn, may bud and continue to produce secondary sporidia in chains in debris and in the leaf whorls of corn plants. A single sporidium may "bud-off" another sporidium in about $3 \mathrm{hr}$. Further, as previously indicated. developing smut gall, under humid conditions, may produce huge masses of aerial sporidia in chains $(36,55,123)$.
Dissemination of spores.-Both chlamydospores and sporidia are readily disseminated by wind and have been caught at high altitudes (318). Over a 2-year period, Pady $(244,245)$ found that chlamydospores of $U$. maydis were common in the air through the year in the vicinity of Manhattan, Kans., but never in large numbers. C. M. Christensen (unpublished results, University of Minnesota) caught chlamydospores at St. Paul. Minn., at intervals throughout the year. Wittich (360) found that they were extremely abundant in the fall. During a smut shower in 1937 , he caught more than 170.000 chlamydospores $/ 1.8 \mathrm{~cm}^{2}$ of surface area of a slide. Unfortunately, the duration of the slides' exposure was not given.

C. MI. Christensen (see 56) estimated the rate of fall for chlamydospores of $U$. maydis at $3.5 \mathrm{~mm} / \mathrm{sec}$, a much slower rate than for urediospores of Puccinia graminis Pers., which are sometimes carried hundreds of miles by the wind. Therefore, it seems likely that chlamydospores of $U$. maydis also may be carried long distances by the wind. Smut inoculum and its distribution do not appear to be the limiting factor in creating an epiphytotic of corn smut in the corn belt of the U.S.A.

Longevity of spores.-Chlamydospores of $U$. maydis readily overwinter outside under different conditions in Minnesota. Just how long they persist in a more temperate climate, especially in regions with high humidity and frequent rains, is not known.

Brefeld in 1883 (34) germinated chlamydospores of $U$. maydis that had been stored indoors for at least 8 years. Piemeisel (261) did the same with 5-year-old spores. Benigni (18), in Italy, failed to germinate spores that were more than 3 years old. Fischer (95) obtained $90 \%$ germination of spores after 2 years of storage. Chlamydospores of $U$. maydis from several different countries also retained their viability for several years in the laboratory at Minnesota. Chlamydospores taken from smut galls stored over winter in bulk lots in gunny sacks germinated readily the next summer. Just how long chlamydospores can persist in nature when mixed with soil is not known.

Very little is known concerning the factors that affect the survival of sporidia. Brefeld (34) concluded that dry sporidia died in about 5 weeks, whereas Piemeisel (261) desiccated sporidia for 5 months without materially impairing their viability. Alternate freezing and thawing were very injurious to moist sporidia, but were not so injurious to desiccated sporidia. Brefeld (35) stated that sporidia lost viability within 8 months when in continuous culture, whereas Piemeisel (261) obtained good infection with sporidia maintained for 8 months in culture. We now know that sporidia can be maintained in pure culture on nutrient media for an indefinite period by transferring them periodically.

Chlamydospores and sporidia of $U$. maydis are readily killed by high temperatures. In water, they are killed within $15 \mathrm{~min}$ at $52^{\circ} \mathrm{C}$. In dry heat. $5 \mathrm{~min}$ at $103^{\circ} \mathrm{C}$ usually is sufficient to kill them, although a greater tolerance to high temperatures has been reported $(5,327)$. In culture, the fungus growing in nutrient solution is killed at $46^{\circ} \mathrm{C}$. There is no information on the effect of high temperatures on spores or mycelium in the living host. But the fungus can be stored at 


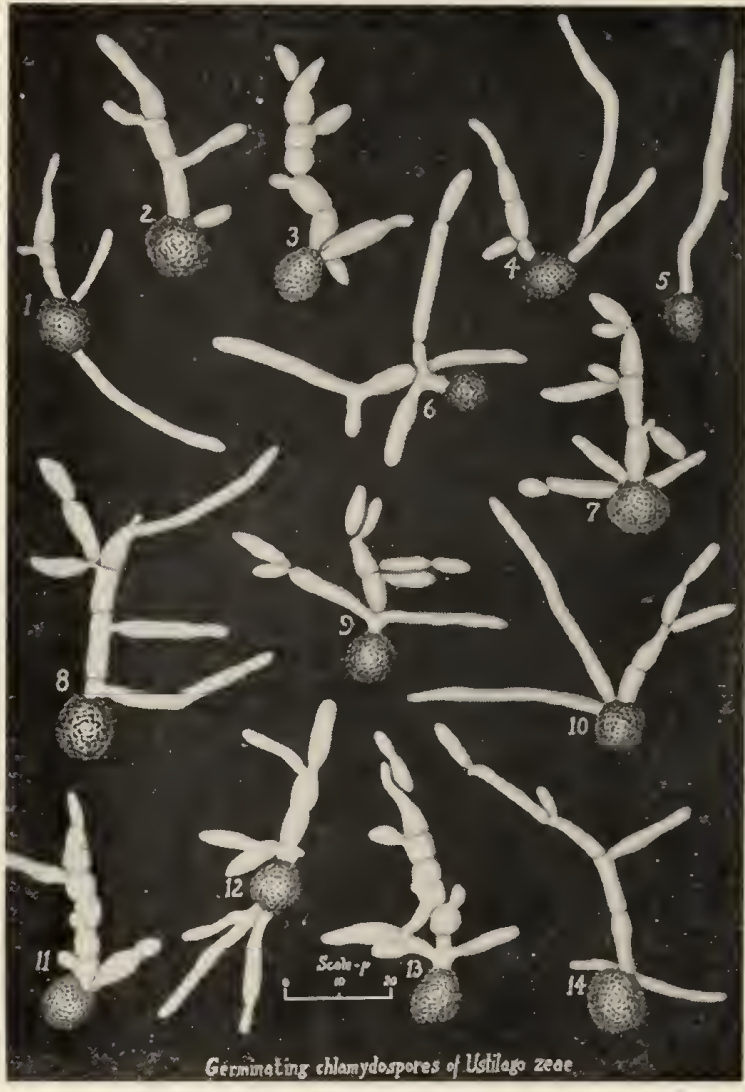

Fig. 7. Camera-lucida drawings of germinating chlamydospores of Ustilago maydis, showing diverse types of germination (Kernkamp and Petty, 182).

about $10 \mathrm{C}$ for a year or two without losing its viability.

Chlamydospores lose their viability in silage after a few weeks (260). This may also happen when they are mixed with manure. especially if fermentation or heating takes place; or if the spores come in contact with destructive agents such as acids, alkalies, and antibiotics. It is generally assumed that sporidia multiply and persist in nature in soil, especially in soils rich in organic material; but this is not supported by experimental evidence. In fact, Jackson (167) has shown that soil prevents chlamydospores from germinating. The writer has obtained similar results with many types of unsterilized soil.

Germination of spores.-The nature of chlamydospore germination depends on environmental conditions and the genetic makeup of the race of smut. Usually, when a chlamydospore germinates on a solid nutrient medium, it produces a basidium called a promycelium. During the growth of the promycelium, meiosis occurs: and then. 3 cell walls are laid down. so the promycelium eventually contains 4 cells. Each of the 4 promycelial cells usually contains a single haploid nucleus and each cell gives rise to at least 1 sporidium.

1) Types.-Although a 4-celled promycelium with a sporidium at each cell is usually illustrated in most textbooks in mycology, it is not necessarily the most common type. Kernkamp and Petty (182) germinated chlamydospores from 8 field collections, 4 crosses between monosporidial lines, and 2 diploid lines. Twenty- five different types of germination were observed (Fig. 7). Some of the more common types were promycelia with $1-8$ cells, promycelia bearing 1 or more hyphal branches instead of sporidia, and the chlamydospore functioning as a basal promycelial cell. In general, the type of germination was associated with the specific collection of smut or cross indicating genetic factors were involved. Environment also affects type of germination; thus, Walter $(350,351)$ concluded that, on the corn plant, chlamydospores usually germinated directly and penetrated the host without the formation of sporidia.

2) Germination in water.-In most cases, chlamydospores of $\ell^{*}$. maydis germinate poorly or not at all in pure water. In this respect, they differ sharply from other cereal smuts. Sometimes, after a rest period, they germinate fairly well in water $(34,305)$.

Stakman (305) found that the promycelia formed in water were rather slender and secondary sporidia rarely developed. In water, the promycelia often gave rise to germ tubes. Sporidia, too, tended to produce germ tubes on a non-nutrient substrate or when the nutrient in the medium approached exhaustion. Platz, Durrell, and Howe (264) obtained good germination of chlamydospores on silicate gel and collodion; both are non-nutrient materials. Clinton (60) also obtained excellent germination in water, although the time required for germination was longer than in a nutrient solution. Chlamydospores that failed to germinate in distilled water germinated readily when a trace of sugar or a small bit of host tissue was added to the water. Apparently, only a very minute quantity of nutrient material is essential for germination; and this may account for some of the inconsistencies obtained in germination of chlamydospores.

3) Germination in nutrient solution.-Brefeld (34), in 1883 , was the first to discover that chlamydospores germinate exceptionally well on nutrient substrates. His work has been verified many times. Without difficulty the writer has germinated, on nutrient media, chlamydospores taken from immature galls. In nutrient media, including manure decoction. Brefeld $(34,35)$ found that secondary sporidia were produced in great abundance and continued to multiply until the nutrient material was exhausted. Brefeld's work indicated that chlamydospores germinate readily in the sterilized soil, especially in that containing manure; and that such a substrate was conducive to growth of secondary sporidia. Since then, many control measures have been recommended on the basis of his pioneer work. There is, however, no adequate experimental evidence that chlamydospores germinate readily or that the sporidia bud extensively in soil or manure in the field. Mrs. Edith Jones (175), in 1923. found that chlamydospores in most cases germinated rarely in unsterile soil, particularly those containing barnyard manure. This is also in accord with the writer's findings. In nature, there are many physical. chemical. and biological factors that may inhibit spore germination and sporidial multiplication. Many of these inhibitors are apparently removed, at least in part. when the material is sterilized.

4) Effect of temperature.-Temperature has a tremendous effect on the percentage, rapidity. and type of germination of chlamydospores. Maire (209) indi- 
cates that optimum temperature for germination of chlamydospores lies between $20^{\circ}$ and $25^{\circ} \mathrm{C}$. This was also the most favorable temperature for sporidial and mycelial development.

Mrs. Jones (175) obtained somewhat different results; the optimum temperature was between $26^{\circ}$ and $34^{\circ} \mathrm{C}$, maximum between $36^{\circ}$ and $35^{\circ} \mathrm{C}$, and spores germinated to a slight extent at $\mathrm{S}^{\circ} \mathrm{C}$. which is not necessarily the minimum. Hüttig (153) found the cardinal temperatures for germination to be: minimum $0^{\circ} \mathrm{C}$. optimum between $20^{\circ}$ and $30^{\circ} \mathrm{C}$, and maximum just below $35 \mathrm{C}$. Temperature may also greatly modify the type of germination. Thus, at about $0^{\circ} \mathrm{C}$. Hüttig found that there was a tendency for chlamydospores to bud off sporidia or hyphal segments rather than produce normal promycelia. At $30^{\circ} \mathrm{C}$. the promycelia frequently gave rise to hyphal branches instead of sporidia. Mrs. Jones (175) also noted less sporidial production at the higher temperatures. The length of promycelia may also be materially influenced by temperature.

The rapidity of germination is of course closely associated with temperature. Hüttig (153) found that the most rapid germination occurred at the higher temperatures. Thus. $96^{c} \mathrm{c}$ of spores germinated at $30^{\circ} \mathrm{C}$ in $12 \mathrm{hr}$ and only $40^{\circ} \mathrm{C}$ at $10^{\circ} \mathrm{C}$ in $16 \mathrm{hr}$. Mrs. Jones 11751 obtained somewhat similar results. Under favorable conditions, the first crop of sporidia will be produced in 12-16 hr; the second crop usually requires only 4-6 hr.

In general, the most favorable temperatures for budding and growth of sporidia lie close to optimum temperatures for chlamydospore germination. The maximum for budding of sporidia is about $40^{\circ} \mathrm{C}$. but at this temperature chlamydospores do not germinate.

5) Special stimulants.-Plazt. et al. (264) concluded that crushed plant tissue stimulated spore germination because the material liberated carbon dioxide. They indicated that an atmosphere with $15{ }^{\sigma_{C}} \mathrm{CO}_{2}$ was optimum for spore germination. whereas an amount above this percentage was inhibitory. They also found the optimum $\mathrm{pH}$ for germination to lie between 4.9 and 5.6. The minimum and maximum $\mathrm{pH}$ 's for germination have not been recorded. Itzerott (162) reported a $\mathrm{pH}$ of 4.4 as optimum for germination, minimum $\mathrm{pH} 2.2$. and maximum $\mathrm{pH}$ S.5.

Leszczenko (197) found that certain inorganic and organic salts and alkalies could stimulate germination of chlamydospores. He attributed this to an increase in the permeability of the spore wall.

Schmitt (290) states that ultraviolet irradiation of chlamydospores retarded germination and the delay increased with the dosage. Pichler and Wöber (259) also reported an injurious effect of ultraviolet irradiation, whereas Kommedahl (156) obtained only a little effect from beta irradiation by the use of radiophosphorus in $\mathrm{KH}_{2} \mathrm{PO}_{4}$. Platz (262) failed to germinate chlamydospores when they were completely immersed in media and kept in air-tight vials.

Most of the studies made on effect of passing chlamydospores through the alimentary tract of animals involved species of smuts other than $L^{*}$. maydis. Cugini (6S). in 1391, found that spores of $\mathcal{L}$. maydis remained viable after passage through the alimentary

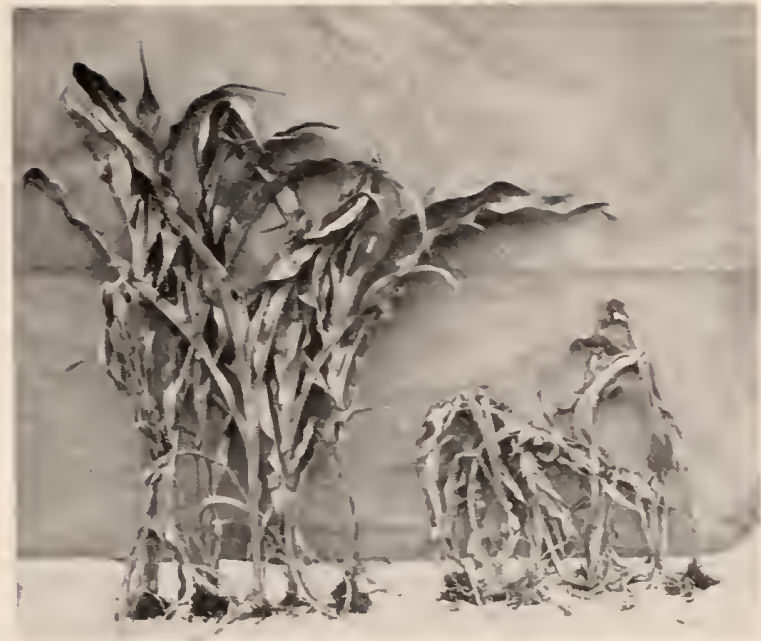

Fig. 8. Reaction of a selfed line of corn to 2 physiclogic races of L'stilago maydis (Stakman and Christensen, 311 ).

tract of cows. whereas Arthur and Stuart (5) claimed they were not viable. Ficke and Melchers (94), in 1929. found that the passage of spores of $L$. movdis through the digestive tract of horses and cattle rendered almost all spores nonviable. Their work indicated that most of the spores lost their viability because of acids present in the stomach. They concluded that the number of spores that remained alive in the feces was too small to be of any importance in the perpetuation and spread of the pathogen.

Methods of Ixoctlatiox-A great many investigators since Tillet have inoculated seed of corn with chlamydospores of $L$. maydis and obtained negative results $(5,25.143)$. Artificial inoculation of corn was not successiul until Brefeld (1883-95) sprayed the corn plant with a suspension of sporidia produced in a nutrient culture $(34,35,36)$. This spray method (which now also involves chlamydospores) has been employed subsequently by many workers (57. 105. 155). More recently. dry chlamydospores also have been dusted on plants. The two techniques have been used extensively in the field for testing lines and varieties of corn for smut resistance.

Application of manure and spores.-Because Brefeld demonstrated that $\dot{L}$. maydis grew readily on manure decoction, it was generally accepted that the application of manure to the soil would tend to increase the amount of inoculum and thus increase smut infection $(34,36)$. Therefore. to create an artificial epidemic of smut, it became a fairly common practice in experimental work to apply barnyard manure mixed with chlamydospores to the test plots or corn rows $(105,158)$. The time of the first application of manure varied from seedling stage to plants about $1 \mathrm{~m}$ high. Sometimes. this treatment was repeated 2 or 3 times at biweekly intervals. In addition. some workers also sprayed the plants at frequent intervals during the growing season with sporidia or chlamydospores.

There are no experimental data to indicate that the application of manure or the frequent spraying and dusting with inoculum actually increased the percentages of smutty plants beyond natural infection. It 
seems likely, however, that inoculation with chlamydospores or sporidia might prove valuable in a region where $U$. maydis is not particularly common.

Injection of spores.-In 1900, Arthur and Stuart (5) injected cultures of smut into seedlings of corn by means of glass tubes. Now, the inoculation of corn plants, especially seedlings, by means of a hypodermic syringe is a common method $(55,118,314)$. Inoculation of seedlings is particularly valuable for testing for sexual compatibility among haploid lines, for testing stability of virulence, and also on physiology of parasitism. The method also has been used to inoculate older plants, which are more useful than seedlings in studying physiologic specialization in $U$. maydis and the nature of resistance to smut (311) (Fig. 8).

The sporidial inoculum can be increased in test tubes or flasks containing about $1 \%$ sucrose or a similar carbon source, plus a small amount of potato or carrot extract. Many other substrates can be used with equal success. The organism is allowed to grow 1-2 weeks before inoculation. Just before inoculation, the culture is diluted $30-50$ or more times its volume with water. Whenever the inoculations are to be made with 2 or more haploid lines, they are thoroughly mixed just preceding injection into the host.

Partial vacuum.-Wilkinson and Kent (358) introduced a partial vacuum method for inoculating corn with smut. Their technique was patterned somewhat after the method used by Moore (230) for inoculating barley and wheat flowers with loose smut. The inoculum was dropped into the spiral whorl of seedlings. Then, the plants were subjected to reduced pressureeracuation to $70 \mathrm{~cm}$ mercury-for $15 \mathrm{~min}$. Then, on the release of pressure, the inoculum was forced into the meristematic region of the leaf spiral. About $85 \%$ of the treated seedlings developed smut.

Wallin (348) wounded seeds and then inoculated them by covering them with a suspension of inoculum and subjecting them to partial vacuum. Apparently, this method is not very effective. at least it is not in common use.

In 1953. Rowell and DeVay (281) again modified the partial vacuum method. Their method consisted of germinating surface-disinfected corn seed under aseptic conditions until the coleoptile was about $1 \mathrm{~cm}$ long. Then, the tip of the coleoptile was cut off to expose the plumule and the meristematic area. The seedlings then were placed in tubes and corered with the suspension of sporidia or chlamydospores to be tested. After that, they were subjected to a partial vacuum for $5 \mathrm{~min}$. The seedlings then were planted in sterile soil or Vermiculite. This method has proved rapid and efficient for testing compatibility of lines and for making genetic studies of the pathogen. In 2 years. Rowell and DeVay (281) made more than 17,000 tests for pathogenicity and sexual compatibility, a good indication of its efficiency. It is not a desirable method for testing lines of corn for resistance, because young seedlings are very susceptible and often killed by the smut fungus ( $\left(\begin{array}{ll}157 & 281\end{array}\right)$.

Whorl inoculation.-Brefeld (34) used successfully the technique of pouring a suspension of sporidia into the leaf whorl of a corn plant. Since then, this method has been used extensively, but in many cases with negative or poor results $(5,263,351)$. Experiments indicate that inoculum does not readily reach the apical meristem because it is tightly enclosed by surrounding leaves. If the leaves do not too tightly enclose the meristem, it can be bathed in inoculum more readily. Lines and varieties of corn differ in this characteristic.

Daris (72) found that the percentage of smutinfected plants was greatly increased when a surface tension depressant such as fish-oil soap was added to inoculum before inoculation. The purpose of the surfactant was to carry the inoculum down through the spiral whorl to make direct contact with the meristematic tissue. Dickson and Bowman (80) obtained good results using this method, whereas Walter (351) did not. Wilkinson and Kent (358) concluded that triethanolamine oleate was a better depressant than fishoil soap as it gave a higher percentage of infection. In order to get consistent results. the authors emphasized the importance of using a nontoxic surfactant which is also stable and uniform in its constitution.

Spiral loosening.-It is well established that the injection of smut inoculum into the growing tissue nearly always results in smut infection. Even forcing dry chlamydospores into the spiral will induce severe smut infection (351). Just how and when most of the inoculum reaches the meristematic tissue of corn is not known. In nature, the presence of inoculum apparently is not the limiting factor because the injection of only sterile water or broth into the leaf spiral when the plants are $30-50 \mathrm{~cm}$ high will greatly increase the percentage of smut (351). The water presumably makes a connection between the inoculum in the upper leaf spiral and susceptible tissue in the apical leaf roll.

Based on the above information, Walter (351) simulated the spiral-loosening effect of the wind by rolling the leaf spirals between the palms of his hands during or immediately following rain. This treatment greatly increased the percentage of smutty plants, especially if the plants were treated after they were about $30 \mathrm{~cm}$ high and before they entered the early boot stage. Walter concluded that heary wind and rain storms caused twisting and bending of plants, bringing the smut inoculum down to the susceptible tissues in the lower part of the leaf whorl.

INFECTION.-Until about 1900, it was generally assumed that $U$. maydis infected young seedlings in the manner of other cereal smuts. Even Brefeld (34) held this view as late as 1883. Kühn (192), in 1874. claimed that he observed the penetration of a germ tube of $L^{\circ}$. maydis into the root-node of a corn seedling. It was Brefeld who from 1883 to 1895 proved that all tender succulent parts of a corn plant above the ground line were susceptible to infection. He established beyond doubt that the place and type of infection were distinctly different from those of other cereal smuts.

Local infection.-Brefeld (34) induced infection by spraying the growing plants with a suspension of sporidia and by dropping them into the leaf whorl of young seedlings. He proved that the galls were the result of local infection and that the corn plant continued to be susceptible to new infection as long as there were succulent and meristematic tissues. He also observed penetration of the smut fungus into many different organs of the plant. 
Recently, it has been established that most of the infection apparently occurred during the leaf-whorl stage of the corn plant, when the plants were $30 \mathrm{~cm}-1 \mathrm{~m}$ tall $(71,267,351,358)$. Then, the meristematic tissue is only a few $\mathrm{cm}$ long and no appreciable elongation of the internodes has taken place. Multiple galls may arise on different parts of the plant from a single infection of the meristematic tissue in the spiral. In such cases, the distribution of the fungus is actually brought about by the host during the elongation of the stalk. The relationship between the host and the fungus is not one of true systemic development.

The germ tubes from either the sporidia or promycelia usually gain entrance by direct penetration. although sometimes ther penetrate through stomata and floral organs. The mycelium is mostly intracellular, although intercellular hyphae are sometimes common. The holes in cell walls through which the hyphae pass are small and the bulging and curling of the enlarged hyphae in the cell strongly suggest mechanical penetration (350).

Haploid infection.-Although haploid hyphae can penetrate the host tissue. dicaryotic or diploid hyphae are essential for normal infection and development of chlamydospores. Rawitcher (273) assumed that the haploid phase was the parasitic stage of $U$. maydis, but this is not supported by more recent work $(59,123)$. Several workers found that haploid hyphae in the host were rather limited in growth. The amount of haploid growth in the host depends on the line of $L^{\prime}$. maydis involved.

Munnecke (236) found that certain haploid lines induced curling and distortion of the host somewhat similar to the hyperplastic phase of normal infection, but no galls or chlamydospores were formed. Haploid infection of the tissues was proven cytologically and also by the reisolation of the original lines.

Several investigators $(234,338,363)$ have shown that $U$. maydis sy.nthesized indoleacetic acid and possibly other auxins in culture and these substances most likely are related to gall development. Therefore, DeVay (77) attempted to supplement the missing stimuli essential for gall formation by inoculating corn seedlings with one haploid line plus the filtrate from a second line of opposite sex. Although the degree of distortion was increased by addition of the filtrate, no chlamydospores were produced.

Rowell and DeVay (282) demonstrated that smut galls and chlamydospores were formed when they paired certain haploid lines of $U$. maydis with specific haploid lines of $S$. reiliana. Since the lines did not fuse to form a dicaryon, some synergistic stimulus must have been involved in this unique phenomenon. The haploid smut galls in corn developed slower than those normally produced by compatible lines of $U$. maydis. No evidence of hybridization was found for any characters that were studied. The size, echinulations, and germination of the spores were all similar to those of the $L$. maydis. All monosporidial isolates obtained from the spores were identical to the original line of $U$. maydis in morphology, cultural characters, and sex factors. None of the isolates produced galls when paired with one another or with the original $U$. maydis line. These isolates were mated to the same $S$. reiliana lines and again produced galls with mature haploid chlamydospores (282).

Composite infection.-- There is no evidence that smut infection may be materially increased by heavy application of inoculum consisting of many biotypes. Sometimes. it may actually cause a decrease in severity. The reason for this is not definitely known, but severe chlorosis and necrosis often follow mass inoculation in the field (351).

Kernkamp and Martin (181) compared the degree of pathogenicity of 13 paired and compatible lines with that of the composite inoculum. The severity of infection of the composite inoculum approached the average severity of the single pairs of haploid lines. Likewise, a mixture of diploid lines alone or in combination with haploid lines did not increase the severity of infection. Wilkinson and Kent (358) and Rowell and DeVay (282) obtained similar results.

Formation of galls.-The parasitic stage of $L$. maydis is a dicaryon. Therefore, if the infection results from fusion of compatible haploids of opposite sex, there is formed a dicaryotic hypha with a stout and rapidly growing mycelium. The mycelium penetrates only a short distance, but ramifies freely in the infected area. Then, the host cells in the invaded tissues begin to multiply and enlarge at an extraordinary rate. Under farorable conditions, the young galls may become visible in a few days and mature chlamydospores mature in 7-9 days after inoculations. Scurti (296) states that the swelling began in advance of hyphal invasion by the fungus. The phenomenon involves both hypertrophy and hyperplasia (184. 297). In addition to the smut mycelium and spores, the galls usually consist of a considerable amount of modified tissue of the cortex. xylem. phloem. parenchyma, and sclerenchyma strands.

The abnormal activity of the infected tissue is due to some active secretion by the fungus. Wolf (362). Turian (338). and others believe that the production of indoleacetic acid by $C^{*}$. maydis stimulates the development of smut galls. They found that young galls had about 20 times greater concentration of indoleacetic acid than noninfected tissues.

Types of hyphae.-There are several different types of hyphae in the host and this may in part account for some of the discrepancies between cytological studies (55. 60, 85). Haploid hyphae are rather fine, usually uninucleate, and not extensively developed. Rawitscher $(273,274)$ was of the opinion that the parasitic mycelium was uninucleate and haploid until about chlamydospore formation. Ehrlich (85) suggested that haploid hyphae sometimes may continue to grow in the presence of dicaryotic mycelium. In culture. sporidia and hyphal cells. whether haploid or diploid, are almost universally uninucleate.

There appear to be several types of dicaryotic hyphae in the host tissue $(55,85)$. The most common one is very irregular and rariable in shape, frequently branched, often contorted. and hence difficult to follow in the host. The second type is rather stout. but usually fairly uniform and rather extensive in growth.

The third type of hyphal growth is a much contorted cluster-like aggregation, somewhat suggestive of a grape cluster. These spherical bodies are apparently composed 
of uninucleate cells and are cut off into segments that eventually become chlamydospores.

Although clamp connections have been reported in the host. their presence has been questioned (59). Clamp-like structures are not uncommon in both dicaryotic and diploid hyphae (55). These structures usually develop into hyphal outgrowths and actual fusion with adjoining cells has not been recorded (55).

In general, the cells in the parasitic mycelium are either binucleate or multinucleate, although the nuclei are often loosely associated in pairs (54, 55, 60). Ehrlich (35) observed 1-6 nuclei cell. although the usual number was 2. Sleumer (301) also reported that the binucleate condition predominated. whereas Lutman (204) reported hyphal cells as multinucleate.

Formation of chlamydospores.-Chlamydospore formation has been described in detail by several workers $(55,60,85,301)$. The hyphae at the time of chlamydospore formation gelatinize and appear as short. angular. and irregular segments. These segments later round up more or less and then a spore wall develops. The spore wall is at first hyaline and smooth. but as the chlamydospores mature they become dark and echinulated. There is no indication that the segments fuse as suggested by Rawitscher (273).

Sleumer (301) and Ehrlich (85) concluded that karyogamy occurs shortly before the segmentation of mycelium. Their observations were based primarily on nuclear size. Most chlamydospores are uninucleate and diploid: some, however, are uninucleate and haploid; others occasionally are binucleate $(55,85)$. Solopathogenic lines resemble dicaryotic lines in respect to the development of the parasitic mycelium and formation of the chlamydospores. except that no nuclear fusion occurs $(55,85)$.

ENirRoNMENTAL FACTORS-There is no general agreement on what weather conditions are most favorable for the development of an epiphytotic of corn smut. It is usually assumed that rain and humid weather are the most critical environmental factors essential for infection.

Moisture.-Arthur and Stuart (5) believed that the sporidia were delicate and easily desiccated and therefore must be kept damp to remain viable, but this is not in accord with the opinions of later workers (261). Moisture is definitely needed for germination and maintenance of germ-tube growth until the host is penetrated. Coffman. Tisdale. and Brandon (63) believe that heary rains may wash the sporidia out of the air and off the corn plant and thus reduce the amount of smut infection. They stated that early spring rainfall induced the chlamydospores to germinate before corn plants were large enough to become infected; hence, large amounts of inoculum may be destroyed. A number of workers $(73,267,350)$ have recorded the production of sporidia in the leaf whorl of corn. According to Platz (263), light rain is sufficient to provide moisture for the multiplication of sporidia in the infection courts. Arthur and Stuart (5) believed that infection takes place during cloudy days or dewy nights and Piemeisel (261) states that cool damp weather favors infection.

If most of the natural infection occurs in meristematic regions of the leaf-whorl. then it would seem unlikely that humidity would be a limiting factor after the inoculum has reached the infection court. For instance, Walter (351) proved that dry chlamydospores forced into the meristematic region germinated and caused infection without the addition of water. There is good evidence that free moisture on the plant is not essential for smut development once the infection is established. When plants are inoculated by the hypodermic syringe method and placed in a relatively dry greenhouse. excellent infections have always resulted.

Dry weather.-Several workers (159. 267) have stated that corn smut is much more prevalent in dry seasons. Potter and Melchers (267) reported that smut of corn was far more abundant and destructive in the western dry and hot portion of the plains in Kansas and Nebraska than in the more humid regions of the U.S.A. They did not believe that lack of moisture was the limiting factor in smut development, whereas MacMillan (205) states that it is the limiting factor in semiarid areas.

At St. Paul. Minn., the effect of certain environmental factors on prevalence of smut was studied from 1922-27. inclusive (159). About 140 selfed lines of corn were inoculated artificially by repeated application of chlamydospores. The results indicated that dry weather. as expressed by a low number of days of precipitation and a high percentage of sunshine. was conducive to development of smut. During these tests, temperature did not appear to be a very important factor (159).

Temperature.-Relatively high temperatures favor chlamydospore germination, budding of sporidia, growth of mycelium, and formation of chlamydospores. Most writers $(281,290,336)$ agree that $25^{\circ} \mathrm{C}$ or above is conducive to development of the smut fungus in the host. Rowell and DeVay (281) obtained much better infection at $28^{\circ} \mathrm{C}$ than at $18^{\circ}$ or $21^{\circ} \mathrm{C}$, whereas Schmitt obtained no gall formation below $21^{\circ} \mathrm{C}$ (290). Tisdale and Johnston (336) also found that temperatures of $25^{\circ} \mathrm{C}$ or above were conducive to infection. whereas temperatures of $20^{\circ} \mathrm{C}$ or below were one of the chief limiting factors. It is well known that smut galls develop and chlamydospores mature much more rapidly at relatively high temperatures than at low.

Conditions that favor or prevent the initial entrance of the smut fungus appear to be of much greater importance in creating an epidemic of smut than those that favor or hinder the fungus development after infection.

Host vigor.-Many workers (5. 193. 298) have stated that vigor of the host was directly associated with susceptibility. Contrary to the common belief. corn smut appears to be least prevalent when the growing season favors steady and normal growth of corn (351). Walter (351) made a detailed and extensive study over a 4-year period on the vigor of the host in relation to smut development. He concluded that sustained rapid development of the corn plant from the seedling stage to full-size plants enabled them to resist or escape the smut. In Europe, similar results were obtained by Maze and Maze (215). It is true that. frequently. the galls are larger and usually 
much more conspicuous on vigorous than on unthrifty corn plants. Vigorous plants may sometimes have fewer concealed galls. those more or less enclosed or hidden by the leaf sheath. hence these plants may appear more susceptible. Further, according to Walter (351), when plants are extremely low in vigor, the number of galls plant may be reduced because of a decrease in the development of nodal buds.

Date of planting.-There are considerable differences of opinion on the prevalence of smut in corn planted on different dates. Many tests have been made; some workers reported more smut in early planting, others less, others obtained no differences in amount of smut in corn planted at different dates.

Arthur and Stuart (5) said that corn planted early developed more smut because it had a greater number of chances to become inoculated and infected. Hitchcock and Norton (1+3) stated that although smut infection becomes visible first on early planted corn. late in the season, irrespective of date of planting, they are all equally smutted regardless of age. Potter and Melchers (266) observed no differences in amount of smut between early or late plantings. In general. Walter (351) found that the smut was more destructive in the late plantings than in the early plantings, but there were exceptions. Before a definite statement can be made on effect of time of planting, experiments should be made on many varieties or lines of corn under many different environmental conditions in different regions of the country.

Injuries to the host.-Aymen (6), in 1760, reported that removal of tassels from plants did not increase smut infection. Since then, there have been several contradictory reports $(73,86,143,351)$. This probably can best be explained in terms of the stage of development of the host at the time of detasseling. This factor also seems to influence the effect of other mechanical injuries, since smut infection seldom develops on injured parts. Multilation appears to have an indirect effect, as it stimulates the development of smut galls in lateral and internodal meristem.

Hitchcock and Norton (143) and Davis (73) secured marked increases in numbers of smut galls by the removal of tassels and ears. Clinton (60) obtained no increase in smut infection by mutilating plants that were a few $\mathrm{cm}$ to $1 \mathrm{~m}$ high, whereas injuries to very young tassels and ears increased infection, especially if the plants were inoculated following the mutilations.

MacMillan (205) recorded a severe epidemic of corn smut following a severe hail storm. Walter (351) failed to increase the severity of smut by puncturing the growing tip of corn plants with a needle or nails. Platz (263) also failed to increase smut infection by mutilating the plants, even when they were sprayed with a suspension of sporidia or dusted with chlamydospores following the injury.

Eldredge (86) showed that there was an increase in the prevalence of smut only if the stalks were injured about 2 weeks preceding the appearance of the tassel. Walter (351) also concluded that injuries induced by mechanical means and by detasseling markedly increased the prevalence of smut provided the damage occurred when the corn plant was in an intermediate stage of rapid elongation.

Rate of planting.-The density or rate of planting of corn in relation to prevalence of smut has long been a subject of much interest. Burger (38), in 1809, reported that thick planting of corn farored the development of smut. Arthur and Stuart (5) stated that thickly planted corn promoted smut development because this maintained the moist air longer. Piemeisel (261) believed that close planting increased the amount of smut because the plants remained succulent for a longer period of time. Kornfeld (187), in Germany, also reported that corn grown close together had a bigher percentage of infected plants than corn grown farther apart.

Wilcoxson and Covey (357) obtained the opposite results; the more spacious planting not only gave a higher percentage of smutty plants, but the severity was 3 times greater on the corn with the less dense population. Their results were based on standard field plot techniques and involved 3 years' data. Davis' (73) results, based on 4 years of extensive field tests, indicated less smut when there were 2 or 3 plants hill than in hills with fewer or more plants. Obviously, it would be desirable to make additional tests on plant populations in relation to smut under different environments using several varieties of corn.

Solopathogens.-As previously indicated, $U$. maydis is predominantly heterothallic, but occasionally monosporidial lines are solopathogenic, causing infection when inoculated singly into the corn plant $(54,84,301,358)$. The frequency of solopathogenic lines is often associated with particular galls and crosses (55). Thus, Chilton (50,51) concluded that tendency for production of diploid lines was associated with lysis of the promycelium, whereas Christensen observed them arising from normal promycelia (55). In any case, solopathogens are not uncommon, because they have been reported from material of diverse origins $(54,55,84,111,301,358)$. The pairing of 2 solopathogenic lines from the same or different chlamydospores did not increase their parasitic capabilities. Likewise, the pairing of a solopathogenic line with unisexual lines from divergent sources does not change the pathogenicity of the former $(55)$.

The solopathogenic lines resemble the unisexual lines in certain characteristics. They grow and multiply like the unisexual lines and the colonies of solopathogenic lines cannot be distinguished from the haploid colonies. Their range in color, consistency, growth, topography, etc., is as great and as variable as unisexual lines (55).

Gattani (111) found that 7 diploid lines differed from one another in rate of growth, ability to digest casein, ability to liquefy gelatin, and growth characters on standard bacteriological media. They also differed in their ability to produce anthocyanin and in their pathogenicity on 4 selfed lines of corn. One line had much greater tendency to mutate than the other 6 .

In certain respects, the solopathogenic lines behave like the dicaryophytic stage of 2 unisexual lines. They are parasitic, stimulate production of anthocyanin 
pigment, and produce normal smut galls. The chlamydospores derived from single solopathogenic lines are of normal shape and size and they germinate and develop normal promycelia. Factors for sexual compatibility, color, topography, virulence. and tendency to mutate segregate in the promycelia exactly as in promycelia of chlamydospores produced by 2 unisexual lines of opposite sex. The sporidia are predominantly uninucleate and hence are apparently diploid in the strict sense of the word.

Solopathogenic lines are as stable as unisexual lines; some mutate frequently on certain substrates, others seldom (55). The stability in virulence is not influenced by the passage through the living host in the mycelial stage nor is it associated with the length of time a given line has grown in culture (55). Some monosporidial lines have maintained their parasitic capabilities for about 30 years, others gave rise to nonvirulent variants within 1 year or a few weeks after isolation (54,111, 203).

Some lines may fail to mutate on one medium, but develop many mutants on another one and sometimes certain media may aid in selecting mutants. When solopathogenic lines are grown on media containing arsenic or lithium, the frequency of mutation and perhaps also vegetative segregation are increased when exposed to radiation. The mutants or the segregates are occasionally avirulent, most likely unisexual, at least some of them cause normal infection when paired with certain unisexual lines $(58,111)$.

Studies by several investigators have shown that solopathogenic lines differ strikingly in parasitic capabilities $(54,55,145,203,358)$. Some are virulent and produce large galls, others are weakly pathogenic and produce very small galls and still others are intermediate in virulence. Some induced the production of an abundance of anthocyanin in certain selfed lines of corn, others did not $(54,203)$. The great range in parasitism among solopathogenic lines especially among mutants derived from the same monosporidial lines is an indication that pathogenicity is not necessarily linked with factors for sexual compatibility (55, 279).

Physiologic Specialization:-The term "physiologic race" was originally used to designate groups within species that differed consistently in pathogenicity. In corn smut, the term "physiologic race" is usually restricted to a collection of chlamydospores that are relatively consistent in pathogenicity on certain lines or varieties of corn. From the practical standpoint, there is little value in dividing $U$. maydis into physiologic races and assigning them specific numbers. Now, it is generally recognized that physiologic races also may differ in cultural characters on artificial media. physiological and ecological characters, biochemical responses, and to a limited extent also in morphology. $U$. maydis comprises an indefinite number of lines or biotypes $(310,314)$. Thousands have been isolated and studied (282, 309). These differ in so many physiologic characteristics and so much in pathogenicity that they could be considered physiologic races. Of course, describing or numbering such races would not be feasible or practical.
Further, U. maydis is predominantly heterothallic, requiring the pairing of 2 compatible haploid lines of opposite sex for normal infection and the production of chlamydospores. New biotypes arise by hybridization: as chlamydospores are diploid and meiosis occurs at the time of germination and new recombinants occur, consequently a changing population of biotypes results in each new sexual generation. New biotypes also arise by mutation. Further, there are excellent opportunities for outbreeding as the chlamydospores and aerial sporidia are disseminated long distances by the wind. Consequently. field infections are usually the results of dicaryons of a diverse genetic constitution. Thus, from a single gall, it is often possible to isolate a vast array of haploid lines and some diploid lines that differ greatly in parasitism. In spite of the heterogeneity of chlamydospores in a smut collection, fairly consistent differences in pathogenicity have been secured in the field with chlamydospores derived from different sources (59). Whenever basic studies are made on parasitism. however. it would be preferable to use dicaryon or solopathogenic lines rather than a collection of chlamydospores which may consist of a mixture of many biotypes.

Parasitic differences.-Melchers (220), in 1921, found that cultures of $U$. maydis seemed to differ in their ability to cause infection when the plants were artificially inoculated. He also indicated that inbred lines and hybrids differed in resistance when grown in different localities in Kansas, an indication of physiologic differences in $U$. maydis. Tisdale and Johnston (336), in 1926, noted slight differences in the parasitic behavior of smut from different sources. They also recorded cultural differences in mass isolates of $U$. maydis.

About this time. Stakman and Christensen (312) demonstrated striking parasitic differences among 12 chlamydospore collections of $U$. maydis. Eleven of these originated from widely separated states and 2 were from Minnesota. Mass isolations were made from chlamydospores and these were used to inoculate 10 varieties of corn that differed greatly in susceptibility to smut. All the cultures caused infection on all the varieties, but differences in the severity of infection on certain lines of corn were sometimes very large. Certain races produced only minute galls on some selfed lines, others produced large smut galls on nearly all lines. Some races differed in their parasitic effect on all 10 lines of corn whereas others differed only on a few of them.

Some races also induced chlorosis of the leaves, often followed by necrosis. The degree of chlorosis and necrosis depended on the race and also on the line of corn. There are similar differences among races and lines of corn in respect to the anthocyanin production. Other investigators found somewhat similar differences in parasitism among 10 other chlamydospore collections of $U$. maydis on 6 varieties of corn $(203,310)$.

The fact that the collections of smut from different states possessed different parasitic capabilities does not necessarily indicate the prevalence of distinct parasitic races in specific regions. A sample consisting 
of 1 to several galls from a given locality certainly is not representative of the smut population for a given region. Even a single acre of corn may harbor many thousand galls and the number of chlamydospores produced would be virtually inconceivable. Then, there may even be from several to many millions of acres of corn within a single state or region. As both chlamydospores and sporidia are readily wind-borne, it seems likely that within a geographical region bounded by natural barriers that the smut population of $U$. maydis would consist of a vast mixture of parasitic biotypes. Experiments made at St. Paul, Minn., tend to prove this $(57,161)$.

Local and nonlocal smut.-Christensen and Johnson (57) made a comparative study for 5 successive years of the response of 5 standard varieties and 95 inbred lines of corn to local and nonlocal collections of smut. The local inoculum consisted of a mixture of chlamydospores derived from several hundred smut galls which were collected at St. Paul. The nonlocal inoculum was obtained from 26 localities in 12 states east of the Rocky Mountains. Each of the 26 collections consisted of many galls and the chlamydospores in the 26 collections were thoroughly mixed before inoculation. The 2 experimental plots were about $3 / 4$ of a mile apart. At frequent intervals during the growing season, the chlamydospores were dusted and sprayed on the plants.

The relative reactions of all the lines of corn to smut were similar on the 2 fields. Lines of corn resistant to local smut collections were equally resistant to smut obtained from widely different sources. There also was a high correlation between the 2 fields in regard to the number of galls/infected plant and to the location of galls on the plants.

The close agreement in smut reaction of the inbred lines to smut collections from widely different sources should be very helpful in breeding for smut resistance in corn. Because of vast numbers of biotypes in $U$. maydis, it would be impractical and futile to breed corn resistant to specific biotypes or races. Therefore, varieties of corn must possess generalized smut resistance or field resistance. This has long been the objective at Minnesota and other institutions where smutresistant corn hybrids have been produced (107, 129, 158, 328).

Phenotypic Variability.-It is important to distinguish clearly between phenotypic modification or variability and true genetic changes and differences. Numerous experiments $(55,314)$ with monosporidial cultures of $U$. maydis have shown that the rate of growth, color. sporidial production of colonies, and other cultural characters may be modified by environmental fluctuations due to temperature, nutrients, vitamins, growth substances, chemicals, hydrogen-ion concentrations, and presence of toxic substances, dyes, and radiation. Phenotypic changes usually revert to original characters when the stimulus is removed.

Several workers $(111,140,203,290,314)$ have clearly demonstrated that standard nutrient media to which various materials are added may have a profound effect on the rate of growth, color, and general topography of the smut colonies. Certain lines of smut may be sporidial on one substrate, but mycelial on another; and sugar tends to increase sporidial growth $(179,314)$. The temperature at which the lines are grown may greatly alter the cultural characteristics and the rate of growth $(256,314)$. The percentage and purity of agar in a medium and kind of liquid culture may also greatly modify cultural growth and appearance of colonies. Even duration of sterilization of a medium may induce sharp modification in the type of growth. Striking changes also occur in the rate of growth and other characters by changing the $\mathrm{pH}$ of the medium. The extent of some of these phenotypic changes is illustrated in Fig. 9.

Semipermanent modifications also apparently occur in $U$. maydis. There is some evidence that some smut lines may gradually acquire tolerance to toxic substances. Stakman, et al. (321) found that monosporidial lines of $U$. zeae increased their tolerance to sodium arsenite in the medium. Certain lines originally tolerated only $2,400 \mathrm{ppm}$ of this salt, but after $10 \mathrm{cul}$ tural generations on this medium they tolerated 7,000 ppm $(142,256)$. The cultural characters of these lines also were altered by the arsenic media, but after several successive generations on arsenic-free media, they gradually reverted to their normal types and also lost their acquired tolerance for arsenic. Later, Gattani (111) studied the adaptation of certain lines to arsenic and malachite green and obtained somewhat similar results. Hirschhorn and Munnecke (142) not only proved that certain lines of $U$. maydis developed tolerance to increasing concentration of sodium arsenite, but the adapted lines also failed to cause infection when paired in the usual way. These lines regained their virulence, at least partially, after a few asexual transfers on arsenite-free media, thus suggesting adaptation rather than mutation. It has been clearly demonstrated that there is a carry-over effect from a physiological treatment or toxic substrate to another medium (257). Naturally, apparent adaptation to toxic materials can arise by mutations and use of mass inoculum consisting of mixed biotypes.

When Petty $(256,257)$ grew a line of $U$. maydis at $21^{\circ}, 32^{\circ}$, and $35^{\circ} \mathrm{C}$ for 5 cultural generations over a period of 6-9 months, he obtained no proof of adaptation to higher temperature. Although phenotypic changes were frequent at $32^{\circ}$ and $35^{\circ} \mathrm{C}$. some of the changes persisted for only 1 or 2 cultural generations and others did not persist beyond the generation of their origin. Mutations in cultural characters were common at the higher temperatures; none of the mutants grew faster than their parents.

Since mutations are rather frequent in $U$. maydis and since toxic materials induce mutation, the possibility of mutation as a cause of adaptation must not be overlooked. Further, because certain mutants may be hidden by the parental culture through many transfers, there is always the possibility of using mixed biotypes as inoculum. Then, too, genetic changes affecting the physiology of the fungus may occur without any apparent change in colony morphology. Obviously, these facts must be given due consideration in any study on adaptation $(53,203,314)$. Unfortunately, detailed genetic analyses were seldom made on the smut populations involved at the end of the experiments. 


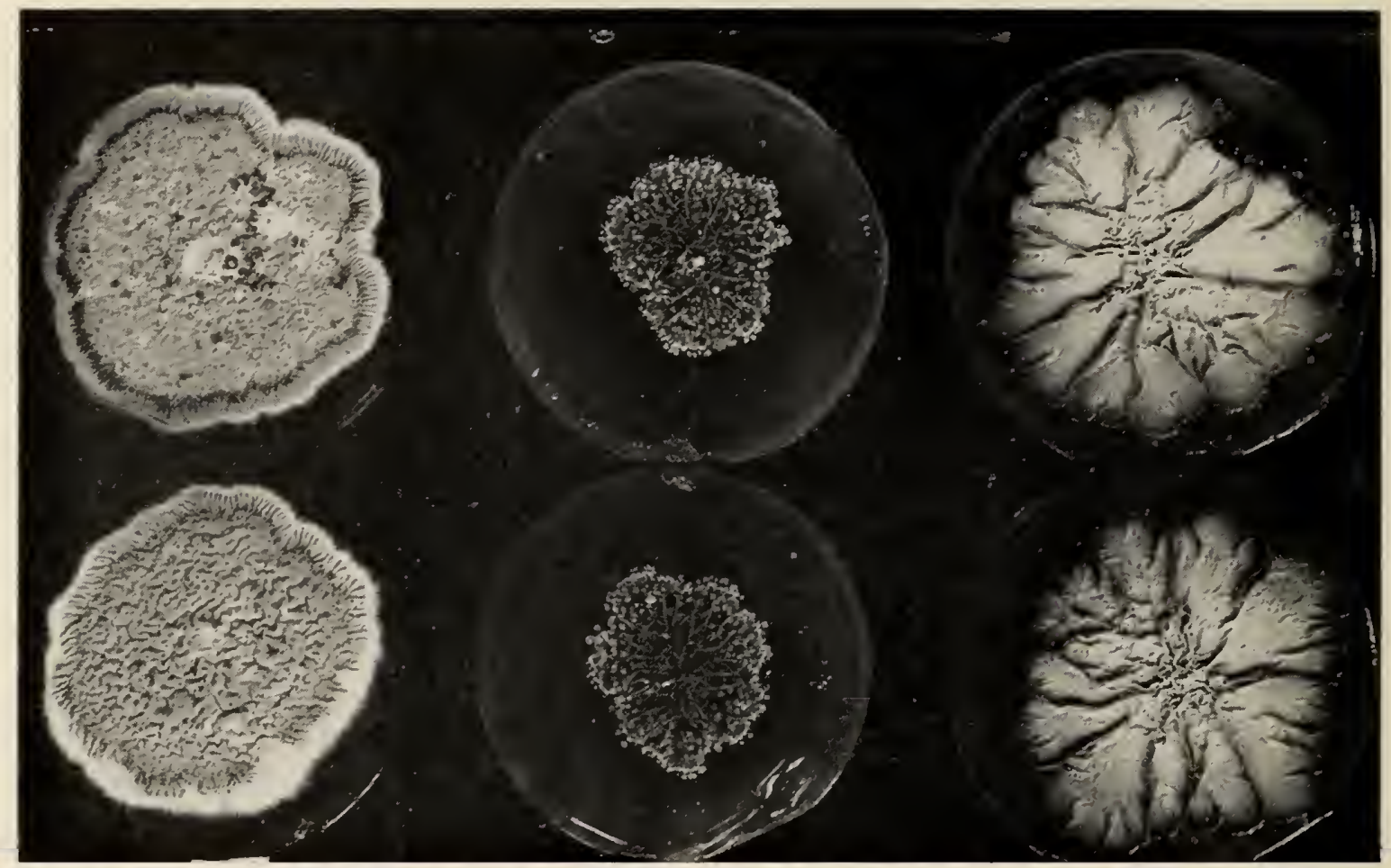

Fig. 9. Phenotypic variability in Ustilago maydis due to differences in nutrients. Duplicate colonies of a monosporidial line of $U$. maydis on 3 different media (Stakman, et al., 314).
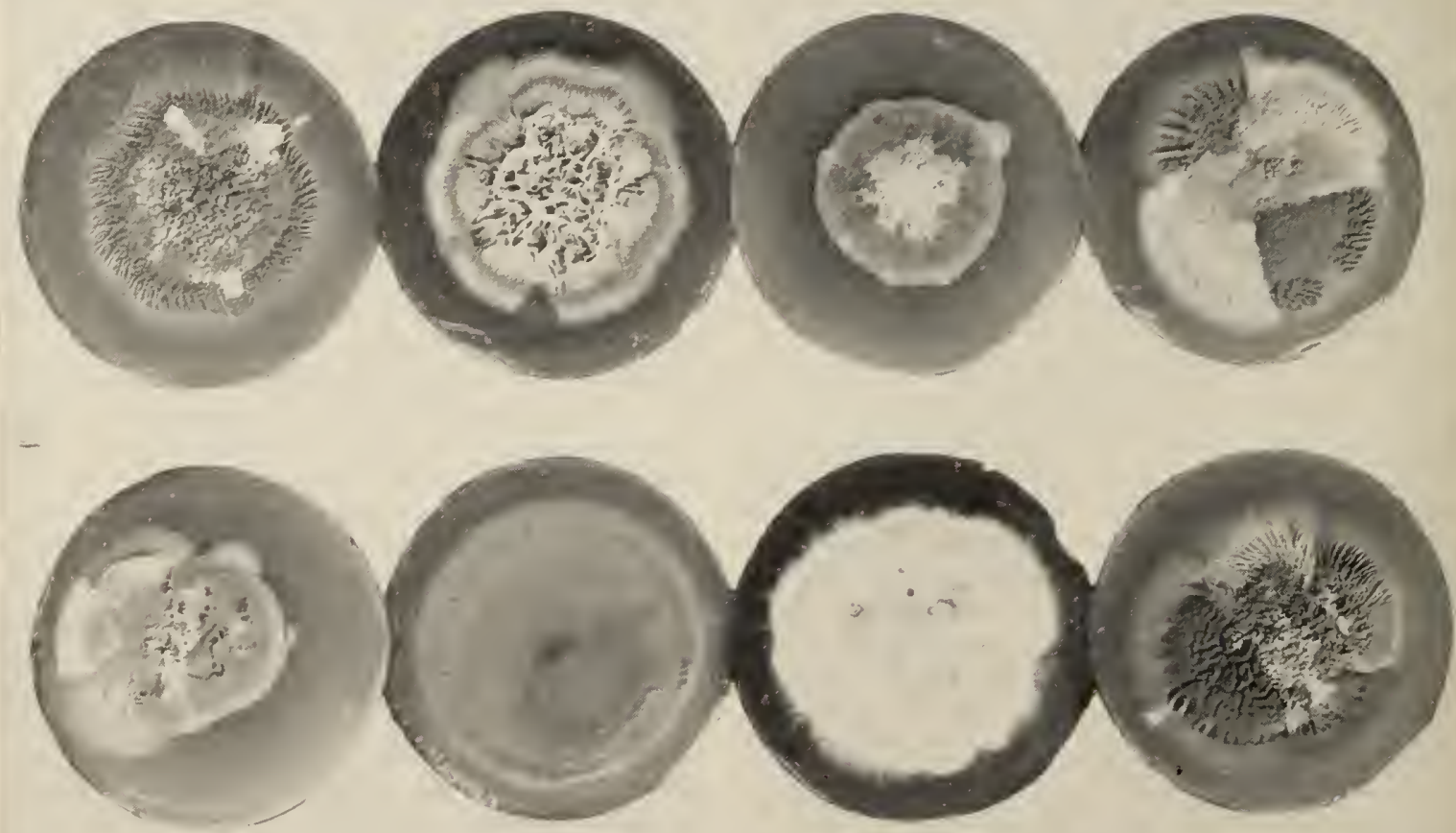

Fig. 10. Seven mutants of Ustilago maydis of a haploid line derived as segregate from a diploid line; parent in upper left hand corner. Mutants again sectoring (Christensen, 55). 
Phenotypic variability and mutation constitute a formidable barrier to precise studies on physiology and inheritance studies of $L$. maydis.

Mutation.-Mass cultures of $U$. maydis frequently become nonpathogenic after many transfers on a solid artificial substrate. Such changes were reported before it was realized that $U$. maydis was heterothallic $(59,312)$. We know now from experiments that the variants could have been due to selecting unisexual lines from a mixed population rather than due to mutants. Since 1927, studies on mutation in $U$. maydis have been based chiefly on monosporidial isolates which are uninucleate and haploid or diploid. Even then, it still possible that some variants that arise in the diploid lines might be due to somatic segregation $(58,111,145)$.

Nuture and type of mutation.-Mutation is one of the primary causes of genetic variation in smut organisms and $U$. maydis appears to be the most mutable species of smut studied so far $(310,314)$. Mutations in C. maydis can occur with respect to virtually any physiological and cultural character selected (Fig. 10). The nature and frequency of mutation in $U$. maydis have been studied at Minnesota continuously for 30 years. During this period, many thousands of mutants have been isolated and studied; and a great many more observed. The types of mutations most commonly observed are the following:

1) Cultural characters, including color, topography, consistency of colonies, direction of growth, nature of margin, zonation, rate of growth, and type of growth (sporidial or mycelial).

2) Physiological characters, including enzyme production, reaction to chemical (including dyes) and toxic substances, response to temperatures, and tendency to mutate.

3) Morphological characters, including size, shape, and color of sporidia; and size of chlamydospores.

4) Sexual compatibility and virulence.

The magnitude of the differences in cultural characters among mutants and their parents was often striking, but sometimes almost imperceptible. For instance, the mutants from a single brown monosporidial line of $U$. maydis varied from near black in color to pure white with an indefinite number of colors between these 2 extremes. Even the degree or shade of "whiteness" may vary tremendously (314, 319. 320). Perkins (254), in 1949, isolated biochemical mutants that required special growth substances. Such mutants should serve as an excellent tool in studying biochemical genetics.

Mutations in shape and size of sporidia are not uncommon in cultures growing on nutrient media (55, 314). One mutant line formed irregular sporidia of diverse shapes, another produced dumbbell-shaped sporidia, and still another produced sporidia which were usually blunt at the ends. Some mutants had a tendency to develop dark pigment in their sporidia. Actually, when certain lines were grown on a special substrate, it was difficult to recognize the sporidia as those of $U$. maydis (55).

There may be pronounced changes in compatibility among haploid lines (314). Although mutation in factors for sex and virulence occasionally occurs,

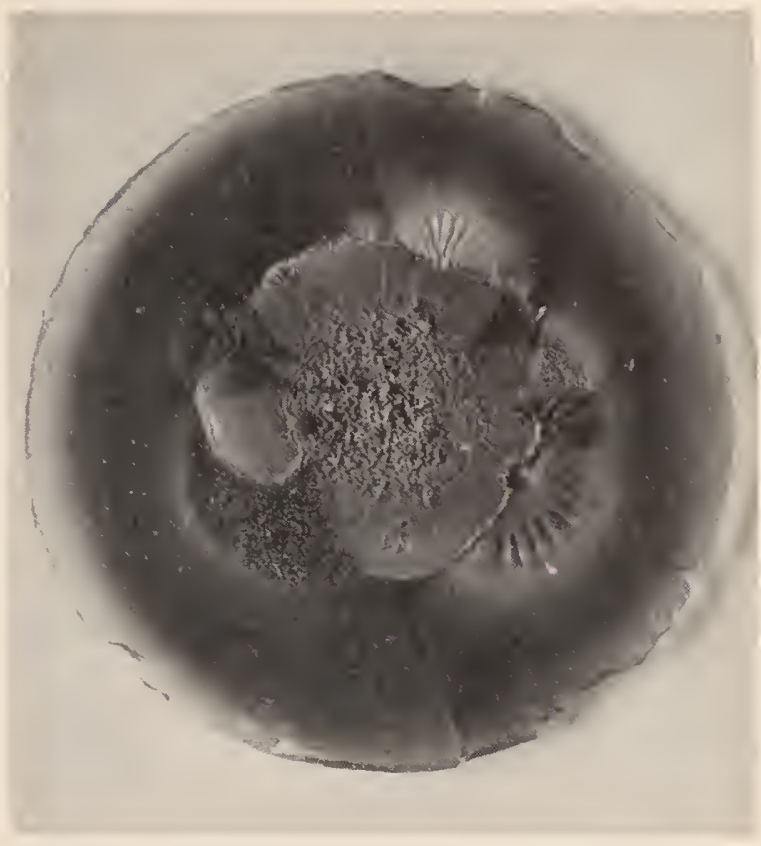

Fig. 11. A monosporidial haploid line of Ustilago maydis growing on potato-dextrose agar and mutating. Mutants arising within a sector (mutant) (Stakman, et al., 314).

mutation for complete sex reversion has never been reported. In $U$. maydis, most mutations of genes for virulence have involved loss of factors for pathogenicity. As in other mutant characters, there may be many changes in degrees of virulence $(54,111,314)$. Diploid lines occasionally produced mutants that failed to cause infection when injected singly into corn plants by means of the hypodermic syringe $(55,111)$. Obviously, it is harder to determine mutation for virulence than it is for certain cultural characters, as the host must be inoculated. Of 15 mutants that Gattani (111) obtained from a single diploid line, 2 were more pathogenic than the parental line. 7 were less pathogenic, and 6 were about equal to the parent in pathogenicity.

Mutation in $U$. maydis is readily detected when the organisms are grown on a solid nutrient substrate. On such a medium. the mutants most frequently appear as a wedge or fan-shaped sector in the colony; more rarely, they occur as irregular isolated patches (Fig. 11). A large percentage of the sectors usually: develop near the edge of a colony although they also may arise at or near the center. The patch mutants may occur any place on the colony, but are generally: more difficult to detect than sector mutants. Sectors vary greatly in size, shape, color, and cultural characters; and also in sharpness of outline (314). Sometimes, small distinct sectors may occur within primary sectors. Many mutants that are not favored by a particular medium are apt to be overrun by parental lines or a vigorous-growing mutant and thus never observed. Obviously, many mutants are not observed because they may appear similar to their parents on the cultural medium on which they arose, but sometimes they are quite different when grown in a different environment. In addition, changes may occur 


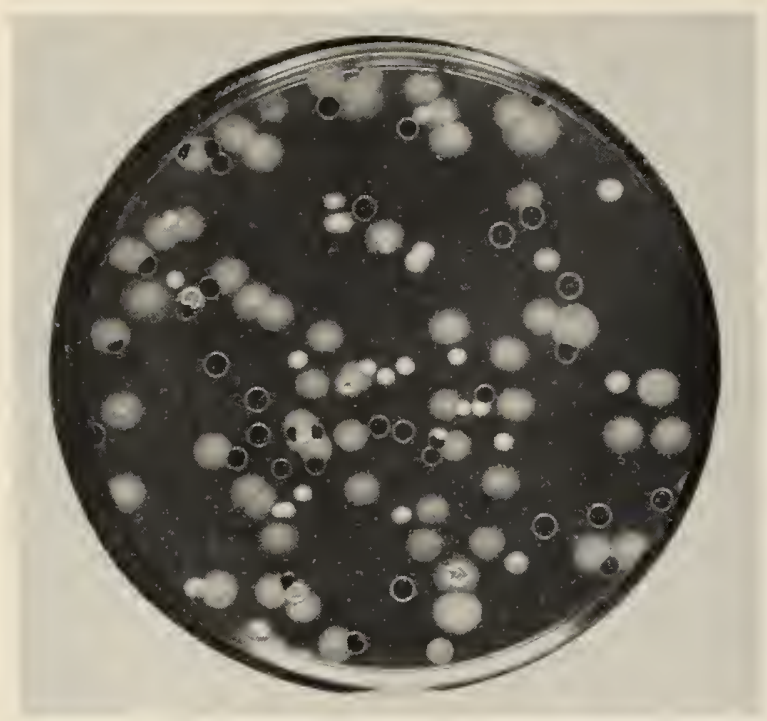

Fig. 12. A surface-dispersed plate of a black monosporidial line of Ustilago maydis grown in a shake culture in potato-dextrose agar. The black line has given rise to several kinds of white mutants (Lu, 203).

in factors for compatibility, virulence, and physiology without obvious modification of cultural characters. Naturally, genetic changes for certain morphological characters such as size and echinulation of chlamydospores and changes in parasitism cannot be ascertained without inoculating the host.

Frequency of mutation.-Although mutation sometimes appears to be extremely common in $U$. maydis, one should bear in mind that in a single sporidial colony, $25-30 \mathrm{~mm}$ diam, there may be many million individual sporidia. Therefore, even if there were 25-30 mutants/colony, the rate of mutation would be relatively low. The mutation rate, however, may be much higher than is readily apparent for there is good evidence that many mutants are overlooked when the organism is grown on a solid substrate. $\mathrm{Lu}$ (203) and Rowell (280) have demonstrated that mutants are often carried along for many cultural generations as cohabitants with their parental line. Certain biotypes in a culture may be slow growers, others fast; some may tolerate a substance and others may be inhibited by it. Therefore, such biotypes may be suppressed during their sojourn on a particular medium. Even the cultures that appear most constant may harbor mutants that may be unobserved in many successive cultural transfers in nutrient media and become visible only when dilution plates are made from shake-cultures. Obviously, this has many important implications in both genetic and physiological studies and in practical application.

The most accurate method for detecting the frequency and kind of mutation is by a surface-dilution method on solid agar medium. This is particularly true if the organism is increased by the shake-culture method. By this technique, Lu (203) demonstrated that the rate of mutation of a black monosporidial line to white was about 1-1,000 (Fig. 12).

Stability of mutants.-There are marked differences in the tendency among monosporidial lines to mutate $(55,314)$. Certain lines of $U$. maydis apparently seldom mutate under a normal range of growing conditions on artificial media, whereas other lines mutate frequently $(54,314,319)$. Moreover, Stakman, et al. (319) found that the tendency to mutate in $U$. maydis was due to genetic factors; and that in certain crosses, there were clear-cut segregations for mutability and constancy. In general, there is a tendency for sporidial lines to mutate more frequently than mycelial lines, but this is not necessarily true $(55,319)$. Some sporidial lines have been remarkably stable; this was true of large populations of sporidial lines isolated from one particular gall (55). Some mutants remain relatively constant through many successive cultural generations, whereas others produce new mutants and these in turn may produce still other mutants and so on (Fig. 13). Mutants with specific characters can be asexually propagated for many cultural generations without any apparent change. Stakman, Tyler, and Hafstad (323) showed that cultural characters of several mutants retained their distinctive characters for several years, although transferred many times and grown under different conditions. The virulence of these mutants which differed greatly from their parent also remained constant for more than 3 years.

There is considerable evidence which indicates that environmental factors affect the frequency of mutation as some monosporidial lines mutate readily on one medium, but seldom if ever on another (314). It is regrettable that in many cases experimental data on the effect of environmental factors influencing the frequency of mutation were based on small samples and on material that lacked genetic diversity. Therefore, many of the results may be indicative rather than conclusive. Stakman, et al. (316) grew 4 monosporidial

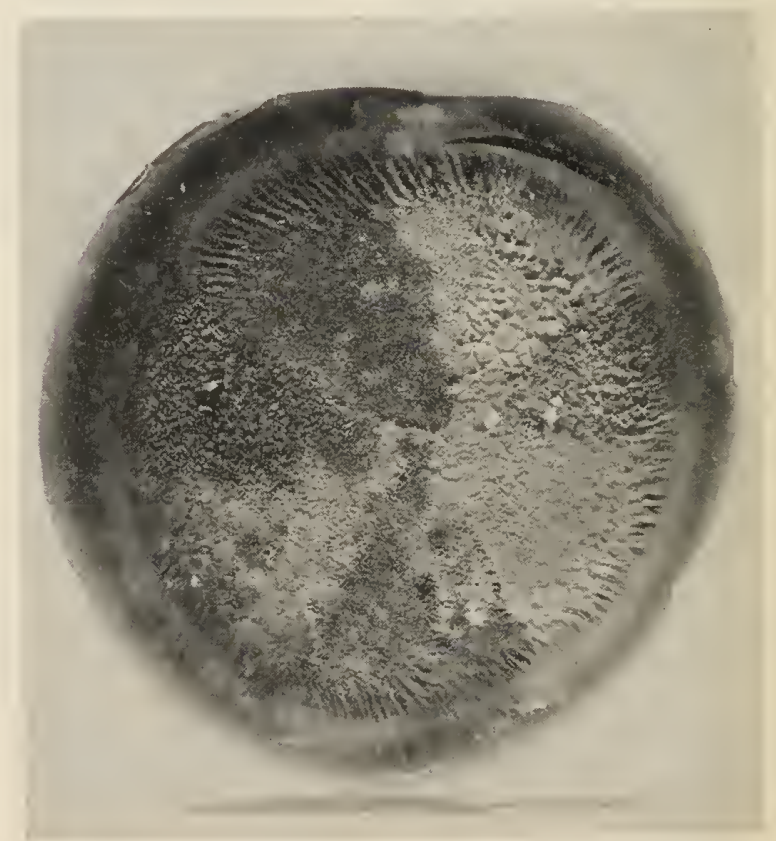

Fig. 13. A mutant of Ustilago maydis which originated through 6 successive mutations and still producing mutants (Stakman, et al., 314). 
lines of $U$. maydis that were derived from 4 states on 15 different solid substrates. Mutation occurred in 5 media, the greatest number was on $3 \%$ sucrose agar containing $0.006 \% \mathrm{NaNO}_{3}$. Both sodium nitrate and calcium nitrate stimulated mutation, whereas ammonium phosphate seemed to inhibit mutation.

Gattani (111) attempted to increase the frequency of mutation by adding the following deleterious substances to potato-dextrose agar: lead nitrate, malachite green, potassium chloride, bismuth nitrate, iron sulfate, mercuric chloride, and uranium nitrate; only the last 2 compounds increased the frequency of mutation. Several other workers have shown that uranium compounds increased the frequency of mutation in $U$. maydis (70.316).

Exposure of cultures of $L$. maydis to ultraviolet radiation. X-rays, and radioactive substances may greatly increase the type and frequency of mutation $(70,111,279,203,144)$. In fact, such mutagenic agents have produced a vast number of mutants that differ strikingly in many physiological, biochemical, and cultural characteristics; and in pathogenicity. By means of ultraviolet light irradiation. Holliday (144) increased the frequency of mutation. By this method, he isolated 100 biochemical mutants, 30 of these were used in genetic studies. Holliday (144) clearly proved biochemical mutants to be most useful as genetic markers in basic genetic studies.

According to Stakman, et al. (314), Petty (256), and Schmitt (290), higher temperatures, $25^{\circ} \mathrm{C}$ or above, are conducive to mutation. Schmitt (290) obtained no sectors in colonies grown at temperatures below $20^{\circ} \mathrm{C}$, whereas the writer occasionally obtained mutation in certain lines at about $20^{\circ} \mathrm{C}$, although mutation rate was much higher at $25^{\circ} \mathrm{C}$ or above. High temperature, like other mutagenic agents, not only increases the frequency of mutation, but induces pronounced and diverse genetic changes and consequently the stock cultures may become a mixture of biotypes if kept at $20^{\circ} \mathrm{C}$ or above. Therefore, it is desirable to store stock cultures of $U$. maydis at $17^{\circ} \mathrm{C}$ or lower in order to inhibit genetic changes.

Genetics of U. Maydis.-Suitable material.- $L$. maydis is a very suitable pathogen for genetic studies. It is a facultative saprophyte and can be grown readily on many artificial substrates under varying, but exacting conditions. Although the sporidia are propagative bodies, they are also gametic in nature. The sporidia are uninucleate, usually haploid, and bud in a yeast-like manner. The progeny of single sporidia are actually clonal lines and constitute biotypes, barring subsequent mutation.

For genetic analysis, complete sets of 4 sporidia can be isolated and their points of origin on the promycelium determined (Fig. 14). In fact, it is sometimes possible to isolate successive sets of sporidia from the same promycelium. As many as 15 successive sporidia have been isolated from a single promycelial cell (319). Consequently, it is possible not only to study the haploid progeny of single chlamydospores, but also the nature and number of nuclear generations involved in meiosis.

There are certain advantages and disadvantages in

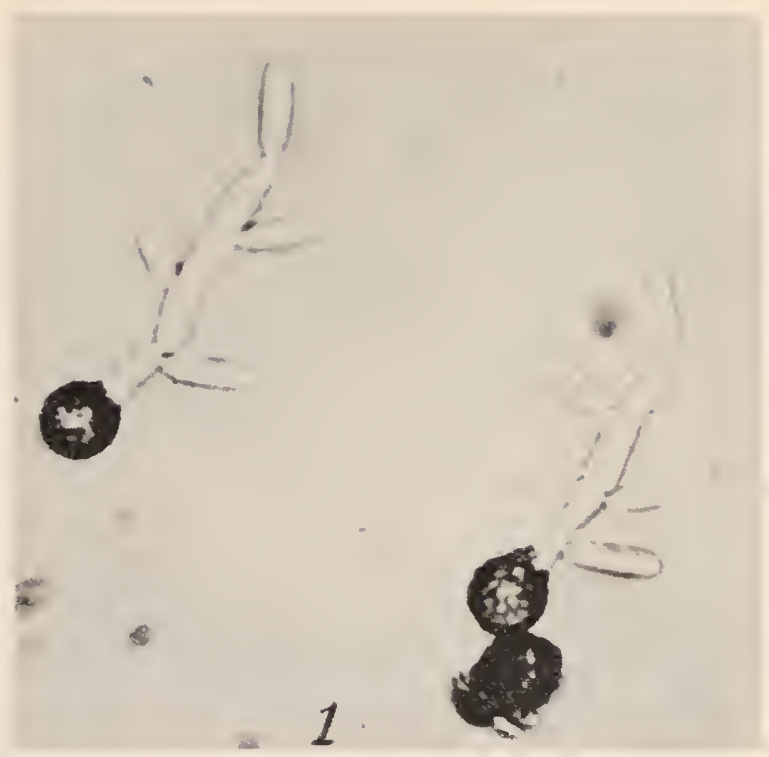

Fig. 14. Germinating chlamydospores of Ustilago maydis with a 4-celled promycelium, each cell producing a sporidium (Stakman, 310).

investigating basic genetical problems in $U$. zeae. The dicaryon cannot be maintained in artificial culture. The true $F_{1}$ generation cannot be propagated independently making it difficult to study segregation. Only the sporidia produced on the promycelium of chlamydospores resulting from a cross can be propagated independently. These can be interpreted as the $F_{1}$ gametes. They can be readily propagated independently on many different kinds of artificial culture media, thus making it possible to study gametic lines under different and exact environmental conditions. The sporidia do not mate readily on artificial media, but they can be paired at will in living corn plants.

The genetic work in $U^{\prime}$. maydis could be greatly simplified if mature chlamydospores could be produced readily in an artificial substrate. Although chlamydospore-like bodies in $U$. maydis are not uncommon in culture, there is no evidence that they behave physiologically like normal chlamydospores (111). Grüss (119) in 1902 reported the production of chlamydospores in artificial media. Other investigators $(111,285,290)$ have observed chlamydosporelike bodies in cultures. Whether these bodies were the results of nuclear fusion or just transformed haploid or dicaryotic mycelium was not ascertained. Gattani's results (111) indicate that chlamydospore-like bodies without distinct echinulation are not uncommon in artificial cultures to which toxic material was added; however, they also produced no promycelia on germination.

Unfortunately, it has not yet been possible to study: the chromosomal behavior, as the nuclei of $U$. maydis are extremely small. Nevertheless, circumstantial evidence for reduction division has been obtained by analyzing the progenies from individual chlamydospores. As the incubation period in the host is relatively short, usually ranging from 10 days to 2 weeks, it is possible to study many successive sexual generations in a single year. 


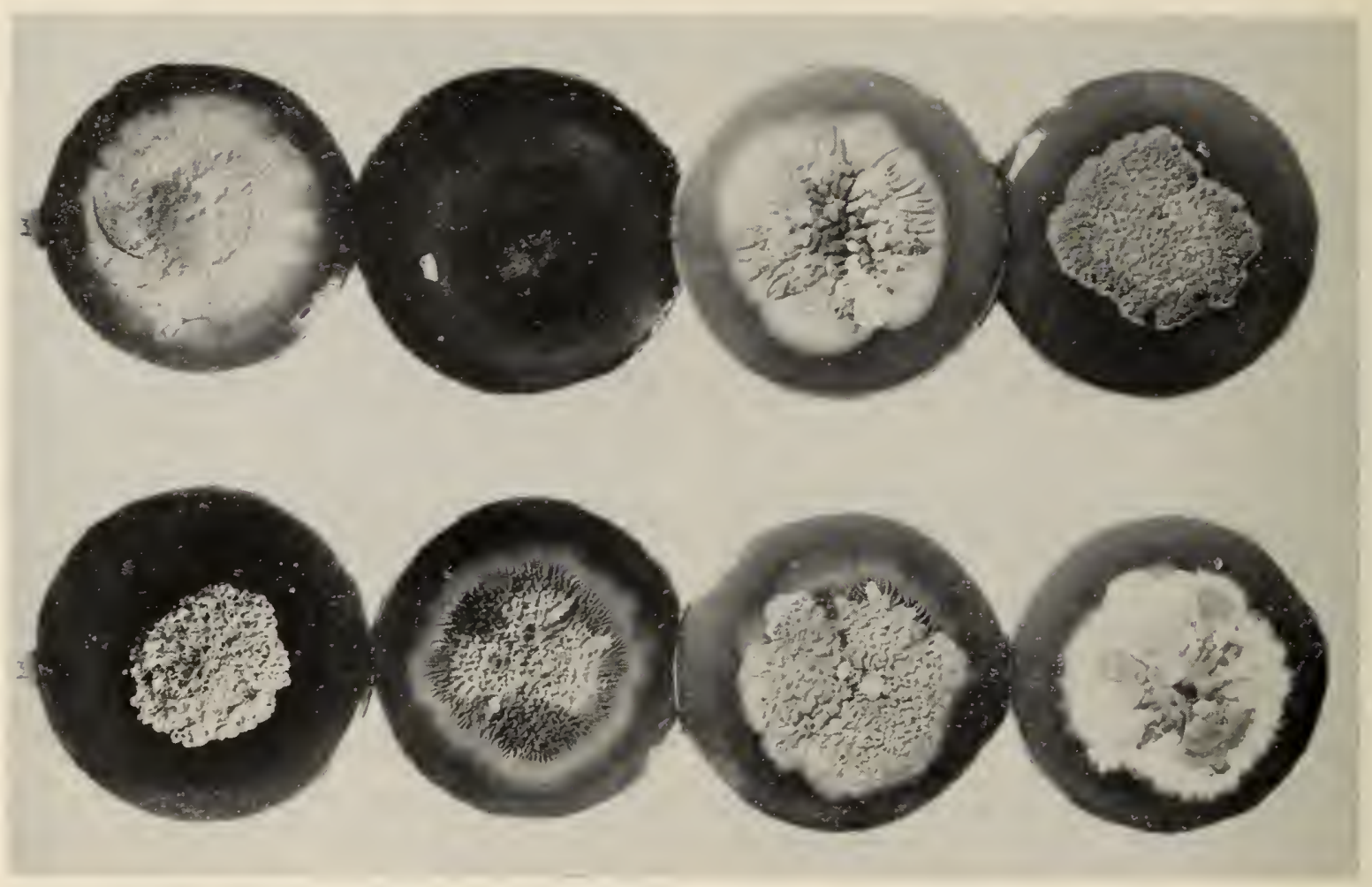

Fig. 15. Monosporidial progenies of 2 chlamydospcres. Left, progeny of first chlamydospore generation of solopathogenic line. Right, progeny of chlamydospore which was produced by a monosporidial line that had shown segregation of cultural factors the previous chlamydospore generation, but not for sex. In this second chlamydospore generation, there was again reduction of factors for cultural characters and also for sex (Christensen, 55).

Nuclear behavior in germination.-As definite information on the nature of germination and of nuclear behavior is prerequisite for correct genetic interpretation of segregation, these phenomena are presented in considerable detail.

Chlamydospores are uninucleate and diploid and meiosis usually occurs during germination and promycelial development. There are many deviations from the normal in both promycelial and sporidial production. The diploid nucleus may divide first in the chlamydospore or it may apparently move out of the spore and then divide (51). There appears to be a difference, in this respect, in chlamydospores from different galls $(55.123,182)$. In either case, one finds a nucleus in the promycelium when it is about $1 / 4-1 / 2$ of its mature length. The fusion nucleus divides and then the 2 daughter nuclei divide again. Three of these nuclei often, although not always, come to lie equally distributed in the promycelium, whereas the other 1 is usually in the chlamydospore. Sometimes, however, all 4 nuclei are found in the promycelium and none can be seen in the chlamydospore. From 1 to 3 cross walls are usually formed. In nearly all cases, a septum is laid down between daughter nuclei of the first division. In many cases, however, the septum between the daughter nuclei of the second division cannot be discerned. The promycelium with 4 primary sporidia is considered the normal type. but it is not the predominant type (182). The primary sporidia usually appear at definite positions on the promycelium. Nevertheless. irregularity in position and in production of sporidia are frequently noted. Some- times 2 or 3 sporidia will bud almost simultaneously from the same cell. It is not uncommon to see 5-7 primary sporidia arising from the same promycelium. If 1 or 2 of the usual 4 primary sporidia are removed before the others have developed, irregularity and mass production of sporidia occur most frequently.

Meiosis.-Meiosis normally involves 2 divisions. Many of the early workers believed that reduction occurred in the first or second division of the fusion nucleus $(54,123,314)$. The apparent segregation of factors in the second division can best be explained on the basis of crossing-over, reduction in chromosomes in the first division and segregation of chromatids in the second. Meiotic crossing-over apparently occurs in $L^{\prime}$. maydis (145). Although linkage has been demonstrated for few characters in $L$. maydis, complete linkage between characters seems relatively rare and it is rather difficult to detect, at least for biochemical factors (145, 180, 319).

Karyogamy. When corn plants are infected by lines of opposite sex, karyogamy usually occurs immediately before gelatinization and segmentation of the hyphae. The actual fusion of nuclei, however, has never been definitely observed. In those rare instances in which mycelial segments after initial fusion are still binucleate. it is possible that another fusion occurs in the chlamydospore. Then, too, the nuclei in a segment might be of the same or different genetic constitution. either in the haploid or diploid condition; or one may be haploid and the other diploid. Therefore, a nucleus in a mature chlamydospore might be in the $2 \mathrm{x}, 3 \mathrm{x}$, or $4 \mathrm{x}$ condition $(55,85,145)$. Sometimes 
a chlamydospore may contain 2 nuclei. Ehrlich (85) observed binucleate chlamydospores and cytological studies indicated that the 2 nuclei could be either 2 haploid or 2 diploid or one of each.

Some chlamydospores give rise to 2 promycelia. From such a spore, monosporidial cultures of 5 distinct types were isolated (55). These could have been the product of a chlamydospore with more than 1 nucleus or the result of mutation.

Delayed reduction.-Meiosis in $U$. maydis does not always occur in a regular manner. Segregation of factors for sexual compatibility and other characters are not always completed in the second division of the fusion nucleus. There may be partial reduction or none at all at the time of chlamydospore germination $(51,55,279)$.

Christensen (54), Eddins (83), and others (52, 203. $301,358)$ obtained uninucleate monosporidial lines that caused infection when injected into the corn plant. They produced galls and normal chlamydospores that germinated like those derived from normal dicaryons and segregation also occurred for sex factors and many cultural characters. Therefore. it was generally assumed that the solopathogens were diploid lines ( 55 ).

Sometimes, the diploid lines can be passed through the chlamydospore stage 2 or more times without any apparent genetic changes; although segregation of chromosomes usually occurs in the first chlamydospore generation. In a few instances, there was segregation of factors for color and cultural characters in first chlamydospore generations, but not for sexual compatibility. In the second chlamydospore generation, there again was segregation of factors for color and cultural characters and also for sexual factors ( 55$)$.

Sometimes, the same promycelium may give rise to both haploid and diploid sporidia $(51,52)$. Reduction of factors for sexual compatibility may be delayed for at least 2 successive chlamydospore generations, whereas in other diploid lines segregation may occur in 2 successive chlamydospore generations (Fig. 15). Obviously, such irregularity in segregation does not fit into the normal scheme of meiosis. Perhaps, the nucleus in the mature chlamydospore was in the tetraploid or aneuploid condition or perhaps certain factors located in 1 pair of chromosomes segregated in the first chlamydospore generation and those in another pair segregated in the second generation. Rowell's (280) discovery of partial diploid lines that are not pathogenic may help to explain this unusual phenomenon of delayed segregation. Holliday (145) also obtained partial diploid lines of $U$. maydis.

Following a high dose of ultraviolet radiation. Holliday (145) isolated a slow-growing unstable segregate which was monosomic and which consistently reverted to a stable diploid, homozygous for 1 chromosome. He states that he also synthesized a triploid which was less stable than the parental diploid (145).

Apparently, meiosis in diploid lines may occur in artificial culture media. Christensen (55), in 1929, found that some of the monosporidial variants of 2 solopathogenic lines were nonpathogenic, apparently haploid; whereas the others were as virulent as the parental line. It is possible that the change was due to mutations which were not uncommon for cultural characters; but

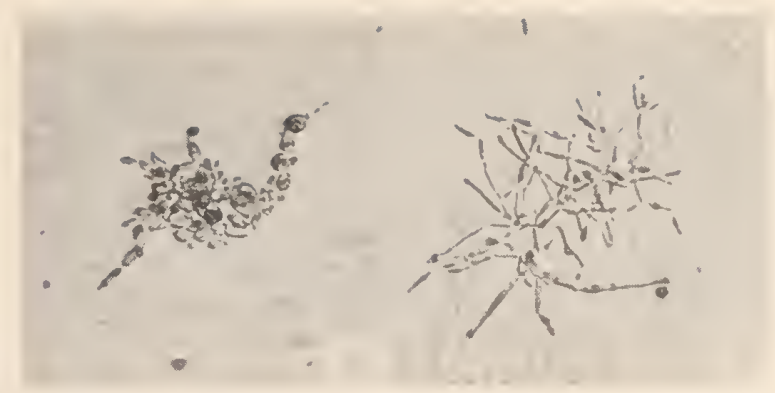

Fig. 16. Young colonies of l'stilago maydis developing from single sporidia of a diploid line. A) Dwarf colony consisting of distorted cells produced in $72 \mathrm{hr}$ from a single cell after the line was exposed to alpha radiation. B) Nonirradiated colony after 24 hr of growth (Rowell, 279).

it seems more likely that somatic reduction occurred in some sporidia, but not in others, during the process of budding. The latter seems most likely as indicated by additional work of the writer and others $(58,111$, 203).

Two years later, similar submonosporidial isolations were made from 2 other solopathogenic lines. Again. a few of the subcultures were avirulent when injected into the corn seedlings. A few of these were paired with unisexual lines and 2 combinations caused infection and galls developed (58). These apparent haploid segregates also differed from their diploid parent in their cultural characters. By growing diploid lines in culture media containing radioactive material, Lu (203) obtained many haploid lines. Occasionally, the parental types were recovered that were used originally in making the cross from which the diploid lines were derived. This is additional proof that meiosis had taken place.

Rowell (279), in 1955, discovered a new phenomenon in sexual behavior of solopathgenic lines. He induced somatic segregation and recombination in 10 diploid lines of $U$. maydis by means of alpha radiation of sporidia. Such a treatment gave rise to many slowgrowing colonies (dwarfs) with distorted cells (Fig. 16). Their rate of growth was only $1 / 1.000$ of that of the parental lines. The dwarf lines were not stable and had a marked tendency to give rise to fast-growing variants. which resembled the original parental lines in type and rate of growth. By growing the monosporidial dwarf lines in a shake-culture of broth and then reisolating monosporidial lines, he obtained many genetic types. At least 6 different unisexual genotypes were isolated from each of the 10 dwarf lines and solopathogenic lines also were reisolated. The dwarf lines remained by far the predominant type. Unfortunately, it was impossible to test the pure dwarf lines for pathogenicity because in a few days they became mixed with fast-growing variants that were constantly arising in the cultures. Rowell (279) concluded that the changes in sex induced by radiation were similar to those that occurred in the same diploid lines during meiosis in the promycelia.

It is not known whether the type of segregation that occurs in the saprophytic stage of $U$. maydis is normal meiosis or a modified type of reduction, perhaps akin to parasexualism. Nevertheless, it has been clearly demonstrated that segregation occurs for sex and 


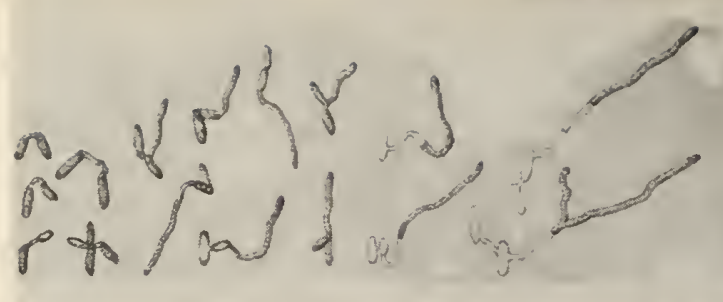

Fig. 17. Sporidial fusion in C'stilago maydis (Brefeld, 34).

cultural factors during the vegetative stage of $U$. maydis (145). In fact, Holliday concluded that mitotic crossing-over occurs in diploid lines, although they are apparently rare and most of the exchanges are single. He increased the frequency of mitotic crossingover by ultraviolet radiation $(145)$.

Number of chromosomes.-Most investigators indicate that it is difficult to determine the number of chromosomes in $U$. maydis $(55,58,85)$. The nuclei in $U$. maydis are small, ranging in diameter from $1.1 \|$ to $2.5 \|$ in dicaryotic hyphae, from $1.7 \|$ to $2.5 \mu$ in diploid hyphae, and from $2.5 \mu$ to $3.0 \mu$ in mature chlamydospores ( 85 ). In general, the diploid number of chromosomes in species of smut fungi is $4(58,98)$. Kharbush (183) gives 4 for $U$. maydis. Eight of the 30 biochemical markers studied by Holliday (145) fell into one or the other of 2 linkage groups, thus indicating that the basic haploid chromosome number is 2 in $U$. maydis.

Fusion.-The tests of sexuality in smut fungi are usually based on the ability of sporidia or hyphae to fuse and develop in the host and eventually produce chlamydospores. It is now well known, however, that in $U$. maydis fusion occurs between sporidia and mycelium of opposite sex in artificial culture. Under certain conditions, it was a rather controversial issue for some time $(123.301,312,314)$. Although Brefeld (34), as early as 18.83, observed sporidial fusion and illustrated it. his work has apparently been overlooked (Fig. 17). Maire (209), in 1898, also illustrated fusion of sporidia in $\mathcal{L}$. maydis, but Hanna (123) indicated that this was perhaps the process of budding rather than conjugation. Somewhat later, Sartoris (285) reported sporidial fusion of $U^{\prime}$. maydis in culture.

Hanna (123), in 1929, observed fusion of germ tubes from 2 monosporidial lines of opposite sex in the tissue of corn, but he did not observe it in culture. Others obtained similar results. Later (1932), Sleumer (301) and Bowman (31) reported fusion of sporidia fairly common on certain substrates.

Recently, Rowell (280) made a detailed study of the genetic factors involved in sporidial fusion. He paired individual sporidia by micromanipulation on drops of dilute corn coleoptile-extract agar. Under these conditions, sporidia fused within 3-4 hr after mating and a distinct hypha developed within 3-4 hr after fusion. Two distinct types of hyphae developed. One type was straight, grew rapidly, branched rarely, and produced aerial chains of sporidia after about $24 \mathrm{hr}$ of growth. These were similar to the vigorous hyphae (Suchfaden) observed by Bauch (12). They caused infection and produced galls. The second type grew slowly, branched frequently, and produced aerial sporidia within $12 \mathrm{hr}$. Sleumer (301) called these atypical hyphae "Wirrfaden" and the resulting dicaryon was nonpathogenic. Rowell (280) concluded that 1 pair of factors governed the process of sporidial fusion, another the compatibility of the paired lines.

Sexual compatibility.-Many studies (54, 55. 282, 301. 316) on the inheritance of sexual compatibility indicate that factors for sex determination in $U$. maydis are much more complex than in most of the other smuts. Hanna (123) concluded that at least 2 pairs of factors, and perhaps more, governed sex determination in $U$. maydis. In 1929, Christensen (54) concluded that sexual reaction in $U$. maydis was due to multiple factors in order to account for 24 sexual groups. The results have been corroborated many times $(55,280,319)$.

In 1951, Whitehouse (355) concluded that there were only 2 sexes present in $L^{*}$. maydis, but he presents no experimental evidence to support his contentions. Recently, Rowell (279, 280) made a most detailed genetic study of sex factors in $U$. maydis. He presents proof that sexual reaction in $L$. maydis is governed by multiple factors and that there are at least 2 loci for sex factors, one of the loci with 2 alleles and the other with multiple alleles. This is the only tetra polar mating which does not have multiple alleles at both loci. He also presented evidence which indicates that sex factors at least sometimes are not associated with pathogenicity (279). Holliday (145) also concluded that the production of chlamydospores in the host is controlled by alleles at 2 loci.

Inheritance of sex.-The inheritance of factors for sexual compatibility was studied by isolating full sets of primary sporidia from a promycelium and then making all possible pairing of the lines within each set. Five segregation ratios of sex factors were obtained: $4: 0,3: 1,2: 2,1: 2: 1$. and $1: 1: 1: 1$ (Fig. 18). The first class actually represents 2 groups. In one group, no apparent reduction of sex factors occurred: all sporidia were diploid and caused infection singly

\section{SMUts - Segregation}

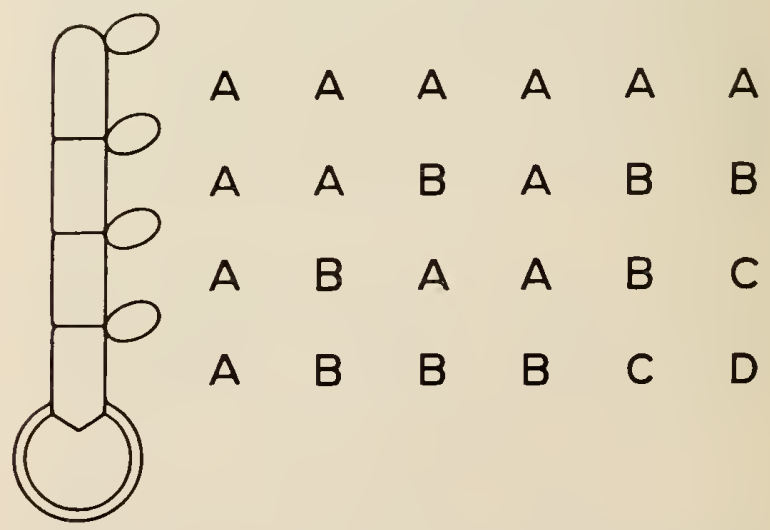

Fig. 18. Graphic representation of 5 different segregation ratios of factors for sex; tendency to mutate; and consistency, topography, color, and radial growth of colonies obtained from individual chlamydospores. (Segregates of one chlamydospore are not necessarily genetically identical with those of another spore with similar letters.) 


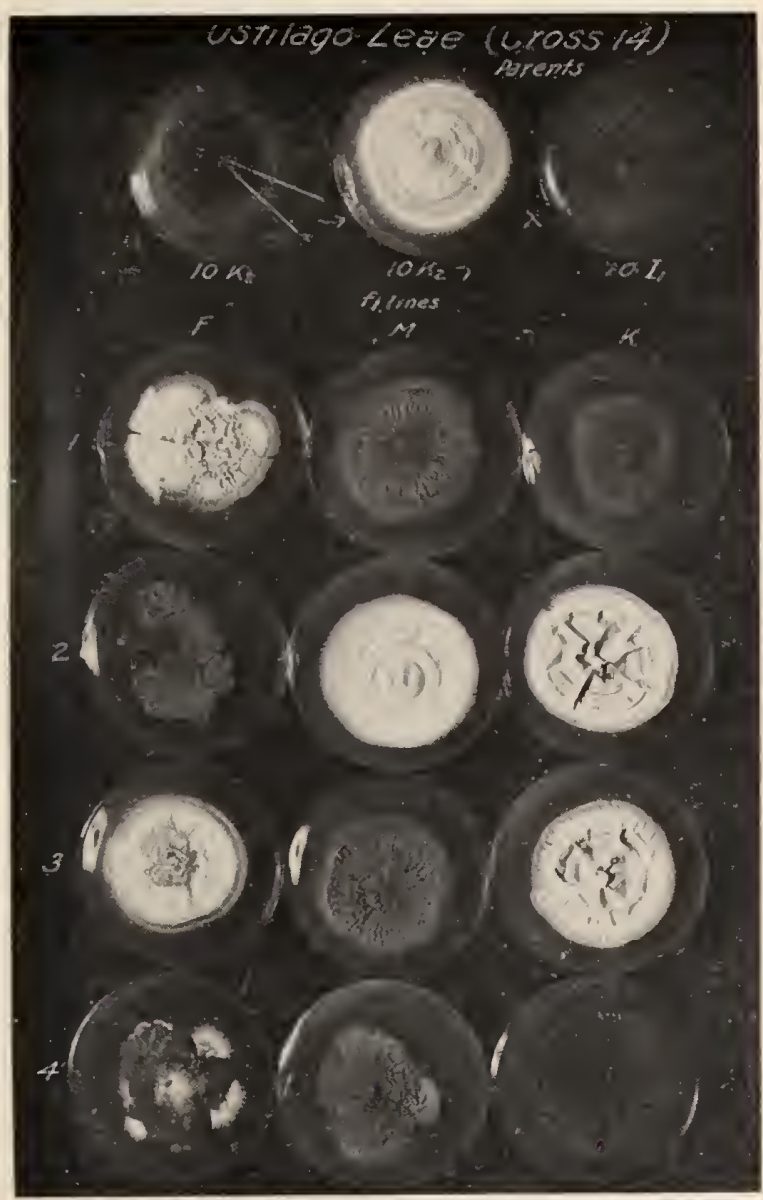

Fig. 19. The haploid progenies of 3 sets of 4 monosporidial lines of L'stilago maydis obtained from 3 hybrid chlamydospores $\mathrm{F}, \mathbf{M}$, and $\mathrm{K}$, resulting from a cross of a mutant, $\mathrm{K}_{2}-1$ with line L (Stakman, et al., 319).

when injected into corn. In the other group, no infection resulted. although the sporidial lines paired in all possible combinations ( 55 ).

This type of segregation for self-sterility is not uncommon in $U$. maydis. Christensen (55) obtained no galls by pairing 16 sets of primary sporidial lines when all possible pairings of lines within each set were made. When these sets of lines were paired with those of chlamydospores from another source, however, there was evidence for regular segregation of factors for sex.

In general. the pairing of lines of the same promycelium results in a low proportion of fertile combinations and the number of sexual groups may be decreased by outbreeding: the progeny from one promycelium may fall into 2 or more sexual groups when paired in all possible combinations. but behave alike sexually when mated with the progeny from another chlamydospore (55). All attempts failed to find 4 monosporidial lines from a single chlamydospore each compatible with all those from another chlamydospore. Sex ratios obviously depend on whether they are based on inbreeding or outbreeding. This fact has frequently been overlooked in making genetic analysis of factors for compatibility.

Inheritance of cultural characters.-Most chlamydo- spores, whether collected in nature or the product of controlled crosses, segregate for cultural characters. Visual observations indicate that the segregates differ in all cultural characters that are possible to observe such as color, consistency, luster, topography, zonation, type of margin, and rate of growth of colonies. Some character differences are very distinctive, others virtually imperceptible. Some may be alike on one medium, but very different on another.

Although most investigators have concluded that there apparently are many factors involved, only a few attempts have been made to interpret them on a strictly factoral basis. Segregation ratios from a given promycelium are $4: 0,3: 1,2: 2,1: 2: 1$, and $1: 1: 1: 1$ (Fig. 19).

The type and extent of segregation of factors for cultural characteristics depend to a large extent on the source of chlamydospores. Thus, from a cross between two contrasting lines, 32 segregates were isolated, all differed greatly in their cultural characters and the parental types were not recovered (54). Even the haploid progenies from a diploid monosporidial line produced numerous distinct cultural lines on a nutrient medium. In another case, 76 unisexual lines were derived from 2 smut galls collected in Germany; and all were almost identical in color, type of growth, consistency, and rate of growth of colonies (55). Unfortunately, these results are based on 1 nutrient substrate. Even the diploid lines resembled the unisexual lines in all cultural characters.

Inheritance of color.-Several attempts have been made to study the inheritance of specific colors of cultural characters. Christensen ( 55 ) crossed a buffcolored line with a brownish-black line. The colors of the segregates when grown on potato-dextrose agar were all as dark or darker than the darker parent and a few were distinctly darker.

$\mathrm{Lu}$ (203) made 7 crosses between a white and relatively stable line and a mutable black line. The

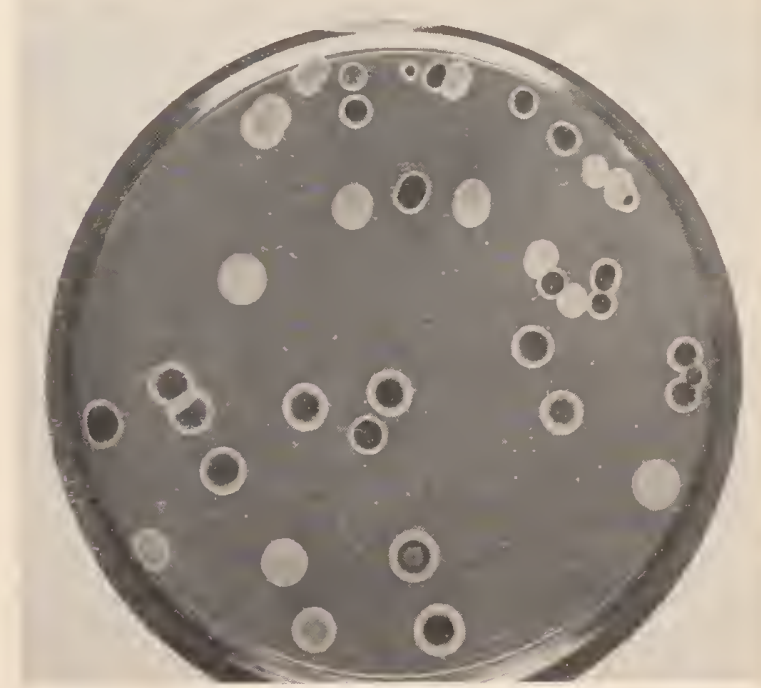

Fig. 20. Colonies from the progeny of a single hybrid chlamydospore (black $X$ white) on potato-dextrose agar in a surface-dispersed plate taken from a shake culture of potato-dextrose broth (Lu, 203). 


\section{Ustilago zeoe (Crass 50)}

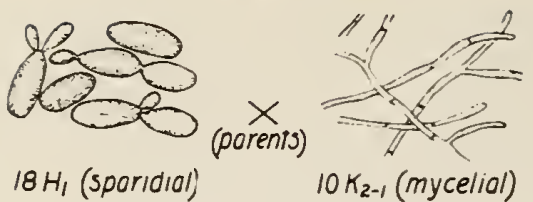

Germinating $F_{1}$ Chlomydospores

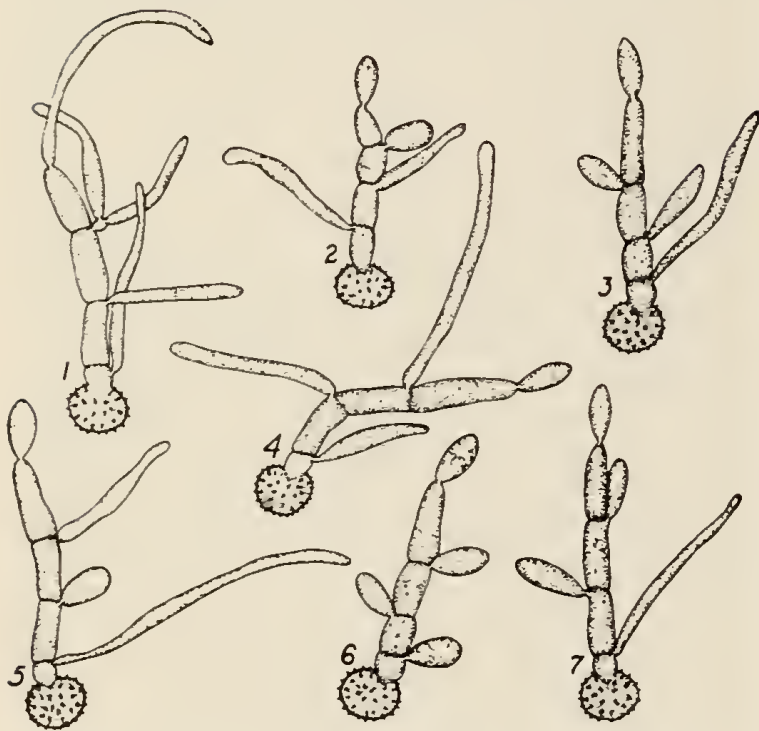

Fig. 21. Growth types of sporidial and mycelial parents and germinating $F_{1}$ chlamydospores showing differences in the production of sporidia and hyphal branches (Kernkamp, 179).

segregants mutated so frequently from black to white and to intermediate colors that it was impossible to determine the number of factors involved in the inheritance of color (Fig. 20). Lu's results suggest that it would be highly desirable to make all segregation studies for color and culture types by the dilution method rather than by mass transfer.

Stakman, et al. (320) made crosses between white and black lines of $L^{T}$. maydis. Although their results indicate a single factor difference, the number of factors involved in color production could not be definitely stated because the progeny of different chlamydospores gave different segregation ratios for whiteness (320). According to these investigators (320). the degree or intensity of whiteness among the isolates was very great. Of course. the intensity of pigmentation may be modified by the consistency and topography of the colonies and the amount of superficial aerial mycelium. Naturally. the kind of medium also may have a profound effect on pigmentation of the colonies.

II tability.-Several workers have repeatedly pointed out that certain lines of $C$. maydis mutate frequently. whereas others were relatively stable $(54,314)$. This led to studies on the nature of inheritance for mutability. Stakman, et al. (319) isolated + primary. sporidia from 1 chlamydospore and segregation occurred for 5 characters including the tendency to mutate. Two lines were mutable and 2 were stable when grown on potato-dextrose agar. The 2 mutable lines developed 360 sectors, whereas the 2 constant lines grown under the same environment produced none. Fortunately, 2 of the mutable lines were of opposite sex and so were 2 of the constant lines and thus facilitated the crossing of desirable lines for genetic studies.

Crosses were made, mutable $\times$ mutable and constant $\times$ constant. The progenies from the former crosses yielded chiefly mutable lines and the latter usually constant lines. These results indicate that mutability and constancy are controlled by genetic factors. Because of the mutability of these lines. Stakman and coworkers were able to isolate more than 5.000 biotypes that traced back to the initial parental cross between 2 lines with contrasting characters. In general. the sporidial lines tended to be more mutable than mycelial lines, but the linkage between the factors for the growth types and the factor for the tendency to mutate was not complete (319).

There is fairly good evidence that the following morphological characters are inherited: tendency to produce sporidia. hyphal branches or hyphal pegs instead of sporidia, size of spores. length of promycelia, and tendency for promycelia to lyse (52). Detailed genetic studies on most of these characters, however, are rather limited.

Hyphal branches.-Kernkamp $(178,179,180)$ recognized 3 types of growth on culture media: strictly sporidial, mycelial, and various intermediates. The growth types of sporidial and mycelial lines could not be changed, whereas the intermediate lines could readily be shifted one way or the other by various environmental factors.

Crosses between mycelial lines tended to produce mycelial growth types. whereas crosses between intermediate lines produce more sporidial lines than mycelial lines. The progenies from crosses between sporidial and mycelial lines gave rise to the parental types, but crosses between many strictly sporidial lines gave no infection (Fig. 21). Cytological studies indicated that these lines lack the ability to develop mycelium in the host, but when outbred they caused normal infection. Kernkamp (180) concluded that the 2 growth types were genetically controlled and 2 or more genetic factors were involved.

Promycelia from certain other crosses tended to develop hyphal branches or peg-like structures instead of sporidia (55). In 1 cross, only about $2 C_{c}$ of the promycelia produced sporidia in a normal manner. In such cases, the promycelium was usually normal. blunt at the distal end: whereas the promycelia of the other $98 \%$ were usually pointed at the end. The pointed promycelia were very inconsistent as to the number of primary sporidia they produced: some developed 4 . others 2 or 3 , and still others only 1 . There was no regularity as to the cell from which the sporidia originated. Nany promycelia never gave rise to any sporidia. but developed a sporidium-like structure that grew directly into a hyphal branch. In many cases, a mixture of sporidia and hyphal branches arose from the same promycelium. A few budded off 1 to 3 or even 4 sporidia and then ceased to develop further; others produced short germ tube-like hyphae and then died; still others failed to grow at all. A 
small percentage of these sporidia appeared to grow perfectly normally (55).

Lysis.-Sometimes, abnormal germination of chlamydospores is associated with lysis of the promycelia. Chilton (50.51. 52) found that chlamydospores from certain crosses produced gnarled and distorted promycelia that either lysed before producing sporidia or developed only a few sporidia in an irregular manner. The factors for lysis were carried only in certain haploid and diploid lines. By making the appropriate crosses, he proved that the tendency for lysis was partialiy dominant and that at least 2 or more genetic factors were involved, as distinctly different degrees of lysis occurred in different crosses. This type of abnormal germination was usually associated with large chlamydospores and the tendency to produce diploid sporidia. Both the haploid and diploid lines that carried the factors for lysis grew normally on nutrient agar. According to Christensen (55), diploid lines are not always associated with lysis of promycelia.

Formation of chlamydospores.-Moore (229). in 1932. found that 3 dicaryophytes, derived by pairing haploids from the same chlamydospore, differed greatly in their ability to form chlamydospores on corn plants. even though they developed numerous galls containing abundant mycelium. One dicaryon rarely produced chlamydospores-and in some galls, none-although it induced large overgrowths. The number of chlamydospores formed also varied with the variety and line of corn inoculated.

Later. Stakman. et al. (320) mated many "white" monosporidial lines in various combinations. Although compatible combinations produced large galls with the normal amount of stout mycelium, no mature chlamydospores developed. When some of these white lines were crossed with tester lines, they developed normal chlamydospores. Apparently, the nuclei of the lines have the necessary factors for attraction and association and growth that enable them to produce the dicaryon and cause infection, but lack the necessary factors for nuclear fusion or factors essential for chlamydospore maturation.

Pathogenicity.-Although it has been repeatedly demonstrated that dicaryon and diploid (solopathogen) lines differ distinctly in their ability to attack different varieties and lines of corn. very little is known about the inheritance of virulence. Even dicaryons derived from the same chlamydospores may differ greatly in pathogenicity. as do solopathogens derived from the same cross (54. 55. 111). Some are very pathogenic and produce large galls. others are virtually nonpathogenic and produce small or incipient galls. and still others are more or less intermediate in their parasitic behavior. Similar differences also occur in the production of chlorosis and anthocyanin pigment on certain inbred lines of corn $(54,111)$.

Great diversity in virulence also frequently arises by mutation in both haploid and diploid lines $(54$. 111, 314. 322). Although most of the changes are associated with loss of virulence. occasionally there is a gain in virulence. Changes in virulence are most easily detected in solopathogenic lines. It is generally accepted that virulence is conditioned by several factors as indicated by great range of virulence among biotypes, especially in diploid lines $(54.55 .111 .280)$.
Toxic Effect of SMut.-Whether corn smut was injurious and toxic to man and animals was controversial from about 1760 to the early part of the twentieth century. According to Burger (38). Tillet and Imhof claimed that chlamydospores of $U$. maydis when eaten by men and animals or when introduced into wounds were not harmful. Imhof (156), in 1784 . ate chlamydospores before breakfast for 2 weeks and introduced them into wounds and used the spores as snuff. but detected no injurious effect. Bonafous (25), in 1936. also ate chlamydospores of corn smut without ill effect.

According to Arthur and Stuart (5). Roulin, in 1829. reported that corn smut was very injurious to men and animals in the low land in Colombia, South America; whereas it could be eaten without deleterious effect in the mountainous upland. ${ }^{1}$ Corn smut has been used for human food for a long time and it still is in some of the Latin American countries (2, 5, 211). Several Mexican publications give recipes for preparation of $U$. maydis dishes. Martinez (211) states that cuitlocoche (smut galls) is collected in the field and carried to the market to sell. Many people use it as food. They chop it into pieces and then fry smut with hot peppers, salt, and several spices. The resulting mixture is put inside of "tortillas" forming "quesadillas." Obviously, the people who eat and relish corn smut do not consider it harmful.

Recent studies show that corn smut can cause human diseases, particularly allergy. Wittich and Stak. man (361) and Harris (125) proved that smuts including corn smut, were responsible for certain respiratory allergies. Preininger's (268) work indicated that corn smut was the cause of a dermatomycosis in man.

Dragisic and Varicak (82) and Mayerhofer and Dragisic (213) concluded that corn smut was the cause of an acrodynia-like disease in children. Later, this type of poisoning was called "Ustilagism" (82).

Several investigators have attempted to isolate the toxic material produced by $U$. maydis. According to Arthur and Stuart (5), several of the early workers thought the active principle had some resemblance to the toxin in ergot. Rademaker and Fischer (269) called the alkaloid substance "ustilagin." Other chemists could not verify their findings. Mitchell (228) found that an extract from the chlamydospore acted on the nervous system of frogs, the action being somewhat similar to potassium bromide.

Some of the investigators did not use pure cultures of $U$. maydis and some were not aware of the tremendous genetic variation within the species of $U$. maydis. This could lead to differences in results. Further, the smut galls produced in nature often harbor many foreign species of fungi and bacteria and these impurities in the material also may help to account for some of the conflicting results.

Most of the early reports on the injuriousness of corn smut spores to animals were not based on ade-

1 Since this paper was written, ergot has been reported on corn in Mexico. Thus it is pessible that erratic effects of toxicity from corn smut could arise from ergot mixed with smut. [Fuentes, S., Maria de Lourdes de la Isla, A. J. Ullstrup. and A. E. Rodriguez. 1962. Ergot of maize in Mexico. (Abstr.) Phytopathology 52:733.] 
quate experimental data. Therefore. some of the harmful effects might have been due to other causes. Arthur and Stuart (5) give a most comprehensive review of the early work on this subject. The long list of publications indicates the interest in this subject at the turn of the last century. Corn smut was suspected of causing general weakness, falling out of hair, abortion, convulsions, paralysis, and even death of animals (5). The so-called corn-stalk disease of cattle also was attributed to corn smut (5). Recently, Ivanoff (165) attributed bronchopneumonia of cattle in Bulgaria to corn smut.

Much of the data on injurious effect of feeding corn smut is still contradictory. The preponderance of evidence indicates that fairly large quantities of corn smut can be fed to cattle. horses. and other animals without any apparent ill effect (5). In 1921 , Ficke and Melchers (94) fed large quantities of corn smut to corvs and horses without harmful results. Some cows relish the smut and milk production was not impaired.

Sut'T Coxtrol. - Many attempts have been made to control corn smut by eradication. such as seed treatment and destruction of smut galls; protection by spraying with chemicals and application of biological agents; cultural practices involving crop rotation and application of fertilizers; and "immunization." the development of resistant varieties.

Seed treatment.- All attempts to control corn smut by seed treatment have failed $(5)$. Therefore, this subject is chiefly of historical interest. Although Tillet (335) and others $(5,25,34)$ proved that smutty seed did not produce smutty plants, seed treatment to control smut was recommended until about 1900 (5). To what extent it was actually practiced is not known.

Most of the experiments on seed treatment, at least in the L.S.A.. were initiated before Brefeld's classic work on life history of corn smut was generally known.

Bonafous (25), agriculturist during the early part of the nineteenth century. suggested treatment of corn with quicklime. marine salt, potash, and other compounds for control of corn smut. Kühn (see 5), as late as 1879 . recommended soaking corn seed in a $0.5 \%$ solution of copper sulfate and this soon became a standard recommendation for control of corn smut.

In the U.S.A., Henry (133), in 1883. reported that seed treatment with copper sulfate and with carbolic acid gave no smut control. Arthur and Stuart likewise failed to reduce smut by treating the seed with a solution of copper sulfate and ammoniacal cupric carbonate. Arthur and Stuart (5) and Stewart (327) made extensive studies on treatment of seed with hot water in an attempt to control smut. All tests on seed treatments were negative. [For additional references on seed treatment, see Arthur and Stuart (5).]

$\zeta$. maydis is readily carried on corn seed; consequently. infested seed lots could easily be one method of long-distance dissemination of the pathogen. Therefore, it would be advisable to treat seed with a good fungicide before it is introduced in smut-free areas or countries such as Australia.

Sanitation.-For almost 200 years, removal and destruction of corn smut galls were recommended by many to reduce corn smut (5.25). During the early part of the nineteenth century, the European writers stated that cutting away the young gall would help to prevent the weakening of the plants: somewhat later, the purpose also was to reduce the inoculum. This practice of smut removal was also strongly recommended in the U.S.A. especially late in the nineteenth century and the early part of the trientieth century. In fact. it is still commonly recommended especially for sweet corn in small gradens. There is no adequate experimental proof, however, that such a practice is of any value, especially in a region where the pathogen is common.

The cutting and ensiling of green corn also have been suggested as a partial control method, primarily because Piemeisel (260. 261) proved that the smut spores were destroyed in the process of ensilage.

Crop rotation.-Crop rotation has also long been recommended as a means of reducing the amount of corn smut, but there is inadequate evidence to support this practice. In 1896, Hitchcock and Norton (143) found that treatment of soil with chemicals did not reduce the prevalence of smut. Selby and Hickman (298) observed more smut on corn growing on newly broken sod than on a field planted to corn for many years. Wilcoxson and Covey (357). on the basis of 3-year field tests, actually obtained a lower percentage of tassel smut when corn followed corn than when it followed a cereal crop. The cause of these differences in amount of smut is not known.

A survey of the literature clearly indicates that the severity of smut cannot be attributed to a particular agricultural practice. W"ind is an effective carrying agent for both chlamydospores and sporidia and this fact must not be overlooked when studying crop sequences.

The successful eradication of $t$. maydis from Australia must be attributed to destruction of smut galls and infected plants. plus the prohibition of growing corn in the infested area. This is an excellent example of successful eradication of a destructive pathogen after it became established in a new country (207).

Application of fertilizers.-Burger (38), as early as 1809 . stated that too much manure favors the development of corn smut. Ever since the early work of Brefeld with manure, it has generally been assumed that the application of manure to the land increased the prevalence of smut. Botanists (5, 36, 190) considered manure a suitable medium for multiplication of sporidia. It was known to increase vigor of the host and hence was thought to predispose corn to smut infection. Most of their conclusions are based on field observations and on meager experimental data.

Starr's (324) work indicated that the commercial fertilizers that increased vigor also tended to increase the amount of smut. Phosphate used alone reduced it.

Schaffnit and Volk (288) found that in greenhouse tests nitrogen increased susceptibility. whereas a deficiency in nitrogen increased resistance to smut. Both an excess and a deficiency in potassium increased susceptibility. Volk (346) found that an excess of NPK favored the development of smut. Greenhouse results based on artificial inoculation are not necessarily good criteria of field resistance to corn smut.

IValter $(350)$. on the basis of a 4-year field test, 
concluded that manure and commercial fertilizers used separately and in different combinations did not alter the amount of smut. This was also true when chlamydospores were added to the manure. Maze and Maze obtained similar results in Europe (215).

Cultural practices.-Although the vigor of corn plants may be greatly increased by good cultivation. there is no clear evidence that there is a corresponding increase to the prevalence of smut. Selby and Hickman (298) obtained no effect on prevalence of smut following deep and shallow cultivation, whereas Clinton (60) reported an increase in the amount of smut with repeated tillage of the soil.

Kyle (194) found that "level-planted" corn developed more "smut than "furrow-planted" corn. He attributed this to differences in vigor of plants. Walter (351) cultivated corn plots by 3 different methods for 3 growing seasons. In spite of differences in vigor of plants. the smut was no more severe in the cultivated than in the noncultivated plots.

Sproying.-Kellerman (177), in 1891, was perhans the first to claim partial control of corn smut by spraying the plants with a fungicide. Smut infection was reduced from $11 c_{c}$ to $i C_{c}$. Stuart (329), in 1895 . and Arthur and Stuart (5). in 1896. reduced the smut with Bordeaux mixture and ammoniacal copper carbonate. The more frequent the application of spray the greater the reduction in smut. Ten sprays with the Bordeaux mixture decreased smut by $72 c^{c}$. Their results do not indicate whether the yield of grain was increased.

Potter and Melchers (266) concluded that partial smut control with fungicidal sprays caused sprayinjury to the plants. A decrease in prevalence of smut also resulted in a corresponding decrease in yield. They believed that chemical injury reduced vegetative activity of the host and hence a decrease in smut infection and a reduction in grain yield.

Pepper and Haenseler (253) eliminated from half to all ear smut by the use of dusts containing either rotenone or nicotine. The insecticides were actually used to control the European corn borer. but Baskin (11) found no association between the prevalence of European corn borer and the incidence of smut. Baskin also found that certain insecticides and fungicides reduced smut infection: Zerlate (zinc dimethrldithiocarbamate) and Fermate (ferric dimethyldithiocarbamate) were most efficient. These results suggest that insects may be important agents in dissemination of inoculum. in creating arenues of entrance for the pathogen, or both. Lnfortunately. very little research has been done on the role of insects in relation to epiphytotics of corn smut. This subject is in need of research.

Since much of the smut infection apparently occurs through the leaf whorl which often harbors chlamydospores and sporidia of $l^{*}$. maydis, proper application of a good fungicide should be an effective means of reducing smut infection. Naturally, the compound used should be nonphytotoxic to the corn yet inhibit the germination of spores or kill the promycelia. The material used by the early investigators did not possess these properties.

The use of antibiotics also should not be over- looked. Bamberg's experiment with living bacteria suggests control by biological methods (7,8). Miss Benigni (18) claims to have induced temporary immunity by vaccination.

Biological control.-Microbiological antagonism may play a very important role in limiting the presalence of $L^{\prime}$. maydis in nature. Fungi and bacteria are often common cohabitants in smut galls. They are also commonly associated with $L$. maydis in the axils of leaves along with dirt and plant debris. Some smut galls become thoroughly infested with bacteria and species of Penicillinm, Aspergillns, Hucor, Trichothecium, and other fungi. To what extent these are parasitic on smut spores is not known. Deckenbach (76) stated that Oospora virticillioides Sacc. is parasitic on $L$. maydis. Sometimes, the consistency of smut galls is greatly modified by the presence of bacteria and the percentage of germination of the chlamydospores may be very low. In 1930. Bamberg (8) isolated a bacterium from corn that destroyed colonies of $L$. maydis. Later. he found additional bacteria that were also antibiotic to $l$. maydis. When the bacterial suspension was introduced into the gall, chlamydospore formation was inhibited. The mixing of bacteria with sporidia before injection into the corn plant materially reduced the amount of infection. Miss Johnson (168) isolated 4 species of bacteria. including a Myxobacterinm, that were antibiotic against $L$. maydis.

In 1948. Cercos (46) described a new species of bacterium, Flarobacterinm ustilagophagunn, which was very antibiotic to $\ell$. maydis. From Bacillus subtilis, Cercos and Farret ( 77 ) isolated an antibiotic substance called "fungocin." It was lethal in small dosages to $U$. maydis growing in culture.

Antagonism is not one-sided, as $L^{*}$. maydis also produces antibiotics that inhibit the growth of other organisms. Haskins (126) found that when $U$. maydis was grown in liquid culture it produced 2 antibiotic substances; one of these was active against several bacteria. the other against several fungi. Haskins (126) designated these as "Lstizeain $A$ and $B$ "; later, Haskins and Thorn (127) changed the term to "Lstilagic acid."

One must assume that in nature $l$. maydis, particularly the saprophytic stage. is subiect to constant biological warfare. This struggle must be especially acute in areas of rich organic material. either in the soil or in the leaf whorls. This may be one of the reasons why smut is most destructive in the semiarid regions. The subject of biological control is very much in need of basic research.

Deielopment of resistant iarieties.-I'arietal resistance.-At present, the only feasible and practical means of controlling corn smut is by growing resistant varieties. It has been known for a long time that varieties of corn differed in their susceptibility to smut. Hitchcock and Norton (143). in 1896. observed considerable differences in percentage of smut on 46 open-pollinated varieties of corn. lo variety was immune. In 1900, both Clinton (60) and Arthur and Stuart (5) reported that sweet corn was especially susceptible to smut. Clinton (60) believed that varieties late in maturity and rank in growth were most likely to become smutty. In more recent times, 
marked differences in susceptibility among open-pollinated varieties have been reported by many investigators $(57,107,129,158)$. It is well known that most field varieties of corn now grown in the U.S.A. are much more resistant than the old open-pollinated varieties, whereas most varieties of sweet corn are still quite susceptible.

Jones (173), in 1918, was the first to demonstrate that inbred or selfed lines of corn derived from the same parental variety differed greatly in their susceptibility to smut. Since then, it has been shown many times that inbred lines of corn can be produced easily with every degree of resistance to smut $(129,158$. 174).

Breeding for resistance.-Several workers have studied the inheritance of resistance to smut in corn. Jones was the first one to make crosses betwen longtime inbred lines that differed in smut reaction. Resistance to smut was dominant in $F_{1}$ and segregation for resistance occurred in $F_{2}$. Hayes, et al. (129) found crosses between resistant and susceptible lines intermediate in reaction, whereas resistant $\times$ resistant lines gave an $F_{1}$ slightly more resistant than either parent. Immer and Christensen (158). Immer (157), and Hoover (148) also found that $F_{1}$ 's from crosses between selfed lines that differed in smut reaction were usually intermediate in reaction. Immer (157) did find a few cases of apparent dominance of resistance to susceptibility. Immer and Christensen (161) found that the $F_{3}$ progeny from a composite cross made of 7 low-smut lines and 1 medium-smut line were predominantly less susceptible to smut than the most susceptible parent.

Linkage groups have been used by Immer (157), Hoover (148), and Saboe and Hayes (283) to study inheritance of smut reaction in maize. Burnham and Cartledge (40) used chromosomal translocation as a means of studying inheritance of resistance to smut. Hayes, et al. (128) by back-crossing a smut-susceptible line with smut-resistant line obtained improved lines that were highly resistant to smut. Further studies are necessary before concluding how many factors are involved. Genetic studies, plus the rapidity with which inbred lines become homozygous for smut reaction, indicate that a relatively small number of factors determine smut reaction. Naturally, the breeding of smut-resistant varieties would be helped materially if the genotypes of the host for smut resistance and the characters involved in resistance were known.

Nature of Resistance.-Little is known regarding the basic nature of resistance of corn to smut and the interaction between the pathogen and the host. Smut resistance appears to be associated with functional, physiological, and morphological characters of corn plants.

There are many conflicting statements about the relative susceptibility of corn at different stages. Some say the plants are most susceptible at $25 \mathrm{~cm}$ high; others, at $1 \mathrm{~m}$; still others observed no difference $(5,34,35,260)$. Although young seedlings usually escape infection in the field, all varieties and lines of corn are extremely susceptible when inoculated by the partial vacuum method or by the hypodermic syringe method. Young seedlings that become infected, whether in the field or in the greenhouse, usually are killed $(118,157,170)$. They appear to be less susceptible as they grow older. By the time the plants become about 15 or more $\mathrm{cm}$ high, they react very differently to different dicaryons of the smut fungus, whether grown in the field or greenhouse (161). This is also the stage of growth most efficient in distinguishing physiologic races (59). Obviously, these differences in smut reaction among selfed lines, when artificially inoculated by the hypodermic syringe method, must be considered physiological. Ranker $(270,271)$ believed that smut resistance was physiological. He found that $U$. maydis grew better in extract of leaves, husks, and stalks from susceptible selfed lines than from resistant lines. He called the toxic agent a smut inhibitor.

It seems likely that young seedlings in nature tend to escape infection because the inoculum cannot readily reach the meristematic tissue. Some believe that corn plants in the field continue to escape infection until just before tasseling because of the tightness of the leaf whorl. Most investigators $(5,25,351)$ have not secured good or consistent infection by spraying of seedlings with a suspension of sporidia or chlamydospores. This type of resistance may be considered functional and morphological.

Griffiths (118) and Platz (263) believed that the relative accessibility of the growing tip when the plants are about $1 / 3 \mathrm{~m}$ tall determines their reaction to smut. Walter (351) found no association between the relative heights of growing tips in the leaf whorls of 81 lines of corn and their reaction to smut.

Morphology no doubt plays an important role in factors influencing both infection and development of smut. Immer (157) and Hoover (148) suggested that certain morphological characters, such as lack of ligules on the leaves, may be associated with the location of smut on the plant. Kyle (193) found an association between tightness of the husk and resistance to ear smut. According to Davis $(72,73)$ and Platz (262), latent smut infection of bud shoots is not uncommon in corn, because of retardation of the growth tissues. Penetration of the host tissues that are too old for smut development has been observed. Therefore, rapidity by which certain tissues mature also may influence gall formation. Walter (351) found no association between the resistance of leaves to puncture as measured by the Joly balance and smut reaction in selfed lines of corn.

Since there are so many parasitic races and biotypes of $U$. maydis, future studies should continue to emphasize generalized field resistance. Lines and varieties of corn should be selected on the basis of their ability to withstand natural infection in the field.

REFERENCES AND BIBliograPHy.-There is a vast amount of literature on the subject of corn smut. I excluded many papers which contributed little or nothing of importance concerning the history or biology of the pathogen such as popular and semipopular articles, especially those on distribution and prevalence of the smut, on control methods, and on the toxicity of smut spores to animals. The papers are given in alphabetical order. 
ridial fusion in Ustilago zeae. (Abstr.) Phytopathology 30:3.

1. Alexopotlos, C. J. 1952. Introductory mycology: John Wiley \& Sons, New York. $482 \mathrm{p}$.

2. Axosrmots. 1891. A scientific review on corn smut. (In Spanish.) La Naturaleza Segunda Ser. $1: 189-195$.

3. Appel, O. 1927. Der Maisbrand und seine Behämpfung. Deut. Landw. Presse 54:596.

4. ARThLR, J. C. 1897. The common Ustilago of maize. Botan. Gaz. 23:44-46.

5. Artiltr, J. C., and IV. Stuart. 1900. Cern smut Indiana Agr. Expt. Sta. Ann. Rept. 12:8t-135

6. Aruex, J. B. 1760. Recherches sur les progres et la cause de la nielle. Mem. Acad. Sci. Paris $3: 68-85$.

7. BAMBERG, R. H. 1930. A bacterium antibiotic to Ustilago zeae. (Abstr.) Phỳtopathology 20:140.

8. BAMberG, R. H, 1931. Bacteria antibiotic to Ustilago zeae. Phytopathology 21:881-890.

9. Barjaxtarovic. S. S., and S. B. Bogdatoric. 1933 Untersuchungen über die Wirkung des Maisbrandes (Ustilago maidis). Arch. Exptl. Pathol. Pharmakol. $173: 381-387$.

10. BARY, A. DE. 1853. Untersuchungen über dic Brandpilze. Berlin. $14.4 \mathrm{p}$.

11. Baskix, A. D. 1947. Studies on sweet corn smut caused by Ustilago zeae. Thesis, Rutgers Univ:

12. Batch, R. 1932. Die Sexualität ron Ustilago scorzonereae und Ustilago zeae. Phytopathol. Z 5:315321.

13. BEAL, II. J. 1880. Indian corn. Michigan Board Agr. Rept. 1880:288.

14. BECK, E. C. 1934. The precipitin ring test applied to some Ustilaginaceae. Can. J. Research (C) $10: 234-238$.

15. BECk, E. C. 1938. The application of serological methods to the differentiation of closely related smut fungi. Can. J. Research (C) 16:391-40t.

16. BEck, G. 1885. Über die Entwickelung von Ustilago zeae Ung. Sitzungsber. Verh. Zool.-Botan. Ges. IVien 35:28.

17. Beckmaxi, J. 1768. Des Herrn Tillet Beobachtung einer Krankheit des turkischen W'eitzens oder des Mais. Hannoverisches Magazin 6:1329-1340.

18. Bexigxi, E. 1927. Note sull' Ustilago maydis (DC) Corda nella Valle Padana. Rev. patol. reg. 17:5772.

19. Bessey, C. E. 1884. The smut of Indian corn. Iowa Agr. Coll. Bull. 1884:127-129.

20. Besser, C. E. 1889. The smut of Indian corn. Nebraska Agr. Expt. Sta. Bull. 1:295-305.

21. Billixgs, F. S. 1889. The "corn-stalk" disease in cattle. Nebraska Agr. Expt. Sta. Bull. 3:165-210.

22. BlaIR, E. S. 1893. Ustilago maidis. Therap. Gaz. Detroit 17:291-292.

23. Blaringhem, L. 1923. Notes sur la biologie des rouilles et des charbons. 3. Infection partielle par les Ustilaginéss. Rev. Pathol. Veg. Entomol. Agr. $10: 246-252$

24. Bo1s, D. 1921. Presentation d'échantillons de maïs attaques par le charbon du maïs et a inflorescences androgynes. Bull. Soc. Pathol. Veg.

25. Boxafous, M. 1836. Histoire naturelle, agricole et economique du Mais, Paris:94-99. (Partial English transl. 1896. Kansas Agr. Expt. Sta. Bull. 62:192194.)

26. Borset, C. 1754. Recherches sur l'usage des feuilles. p. $32 \nmid-330$. Gottingue.

27. Borgiard, A. I. 1932. The present state of our knowledge of the diseases of Maize. (In Russian.) Sci. Research Inst. for Maize and Sorghum Cultiv. Kniepropetrovsk. Publ. 28:1-53.

28. Borzixi, G. 1935. Il 'carbone' del granturco nell'annata 1934 nella regione dell'Agro Romano. Boll. staz. patol. veg. Roma N.S. 15:96-115.

29. Borzixi, G. 1935. Ricerche sul 'carbene del Granturco' ('Lsti'ago zeae (Beck) Unger). Boll. staz. patol. reg. Roma N.S. 15:389-423.

30. Bowmax, D. H. 1940. Cytological studies of spo-
31. Bowmax, D. H. 1946. Sporidial fusion in U'stilago mavdis. J. Agr. Research 72:233-243.

32. Braxda, J.S. 1941. Os "carvoes" dlo milho. Brasi! Ministero da Agr. Bol. 30:31-33

33. BraUNSteIN. 1897. Influence de l'Utstilago maydis et des stigmates du maïs sur les contractions de l'uterus. Arch. Russ. de Pathol., de Méd. et de Bactériol. 1897:339.

34. BREFELD, O. 1883. Botanische Untersuchungen über Hefenpilze. Untersuchungen aus dem Gesammtgebiete der Mykologie V. Die Brandpilze. 1. Leipzig. 220 p.

35. Brefeld, O. 1888. Neue Untersuchungen über die Brandpilze und die Brandkrankheiten. II. Nachr. aus d. Klub d. Landw. Berlin 1888:1577-1584, 1588-1594, 1597-1601. (E. F. Smith. English transl. J. Mycol. 6:1-8, 59-71, 153-164. 1890-91.)

36. BREFELD, O. 1895. Die Brandkrankheiten des Getreides. Untersuchungen aus dem Gesammtgebiete der Mykologie. XI. Die Brandpilze. 2. Münster. 98 p.

37. Brefeld, O., and R. FALK. 1905. Die Blüteninfektion bei den Brandpilzen und die naturliche Verbreitung der Brandkrankheiten. Lntersuchungen aus dem Gesammtgebiete der Mrkologie. XIII. Die Brandpilze (Hemibasidii). 4. Münster. $74 \mathrm{p}$.

38. Burger, J. 1809. Obhandlung uber die Naturg. Cultur u. Bemitz. des Mais. p. 242-243. Wien. (Abstr. Kansas Agr. Expt. Sta. Bull. 62. 1896.)

39. Burk, E. F., C. B. Cross, and E. Hixsox. 1936. Variety tests of sweet corn and its resistance to corn earworm and smut injury. Proc. Am. Soc. Hort. Sci. 33:502-504.

40. Burnhal, C. R., and J. L. Cartledge. 1939. Linkage relations between smut resistance and semisterility in maize. J. Am. Soc. Agron. 31:924 933.

41. Butler, E. J. 1918. Fungi and disease in p'ants. Calcutta and Simla. 547 p.

42. Caxel, M., and G. J. Fischer, 1949. La intensidal del ataque de carbon en los maices castrados. Arch. Fitotecnico del Uruguay 4:18-19.

43. CASE, A. A. 1956. Corn smut in silage. Am. Vet. Med. Assoc. J. 129:404.

44. Castellaxi, E. 1940. Problemi fitopatologici dell'Impero. Oscervazioni ed orientamenti. Agr. Colon. $34: 5-15$.

45. CATSkA, I. 1957. The incidence and iso'ation of a bacterium antagonistic to Ustilago zeae. (In Russian.) Ces. Mikrobiol. 2:318-323.

46. Cercos, A. P. 1948. Accion antibiotica de Bacillus mesentericus sobre Ustilago maydis Votros hongos. Rev. de Invest. Agr. (Argentina) 11:37-56.

47. Cercos, A. P., and E. A. Fairet. 1946. "Ustilago maydis" una nueva fuente de radiación mitogenética. Rev. Argentina Agron. 13:128-137.

48. Chifflot, J. 1907. Sur la présence de l'Ustilago maydis (DC.) Corda sur les racines adventives du Zea mays L. et de sa varieté quadricolor. et sur les biomorphoses qu'elles présentent. Compt. Rend. Acad. Sci. Paris 144:764-766.

49. Cinfflot, J. 1909. Sur la Castration thelygène chez Zea mays L. var. tunica, prcduite par 1'Ustilago maydis (DC.) Corda. Compt. Rend Acad. Sci. Paris 148:426-429.

50. Chiltos, S. P. 1938. The occurrence of lysis in certain crosses of Ustilago zeae. (Abstr.) Phytopathology $28: 5$.

51. Chiltox, S. P. 1940. Delayed reduction in the diploid nucleus in promycelia of Ustilago zeae Phytopathology 30:622-623.

52. Chiltox, S. P. 1943. A heritable abnormality in the germination of chlamydospores of Ustilago zeae. Phytopathology 33:749-765.

53. Christensex, C. M., E. C. Stakmax, and J. J Christexsex. 1947. Variation in phytopathogenic fungi. Ann. Rev. Microbiol. 1:61-84.

57. Christexsex, J. J. 1929. Mutation and hybridi- 
zation in Ustilago zeae. II. Hybridization. Minnesota Agr. Expt. Sta. Tech. Bull. 65:89-108.

55. Christensex, J. J. 1931. Studies on the genetics of Ustilago zeae. Phytopathol. Z. 4:129-188.

56. Christensen, J. J. 1942. Long distance dissemination of plant pathogens. Am. Assoc. Adv. Sci. Publ. 17:78-87.

57. Christensen, J. J., and I. J. Johnsox. 1935. Field reaction of varieties and selfed lines of corn to different collections of Ustilago zeae. J. Agr. Research $51: 47-57$.

58. Christensen, J. J., and H. A. Rodenhiser. 1940. Physiologic specialization and genetics of the smut fungi. Botan. Rev. 6:389-425.

59. Christensen, J. J., and E. C. Stakmax. 1926. Physiologic specialization and mutation in Ustilago zeae. Phytopathology 16:979-999.

60. Clinton, G. P. 1900. The smuts of Illinois' agricultural plants. Illinois Agr. Expt. Sta. Bull. 57.

61. Cliston, G. P. 1904. North American Ustilagineae. Proc. Boston Soc. Natl. Hist. 31:329-529.

62. CobB, N. A. 1891. Diseased maize plants. Agr. Gaz. New South Wales 2:285.

63. Coffmax, F. A., W. H. Tisdale, and J. F. Brandon. 1926. Observations on corn smut at Akron, Colorado. J. Am. Soc. Agron. 18:403-410.

64. Corda, A. C. J. 1848. Der Kornbrand. Oekonomische Neuigkeiten und V'erhandlungen 1848:9-12.

65. Craig, J. 1886. Observations on corn and corn smut. p. 16. Bull. Iowa State Agr. Coll.

66. Craigie, J. H. 1939. Economic diseases of field crops in Manitoba. p. 1-37. Economic Survey Board, Manitoba, Canada.

67. Cravioto, R. O., G. H. Massieu, J. G. Guzmáx, and J. C. DE LA TORRE. 1951. Composición de alimentos Mexicenos. Ciencia 11:129-155.

68. Cugini, G. 1891. Il carbone del grano turco. Bol. R. Staz. Agr. Modena N.S. 19:71-87.

69. DADE, H. A. 1924. A corn dicease. J. Go!d Coast Agr. Commercial Soc. 8:84-85.

70. Daly, J. M., and S. I. Lu. 1950. Cultural characters of uranium-nitrate-induced mutants of Ustilago zeae. (Abstr.) Phytopathology 40:6.

71. DAris, G. Y. 1932. Relation of axillary-bud development to nodal smut infection in the corn plant. (Abstr.) Phytopathology 22:7-8.

72. Ditis, G. N. 1935. Some new aspects of maize smut. Iowa State Coll. J. Sci. 9:505-507.

73. DAvis, G. N. 1936. Some of the factors influencing the infection and pathogenicity of Ustilago zeae (Beckm.) Unger on Zea mays L. Iowa Agr. Expt. Sta. Research Bull. 199.

74. Divis, S. 1900. Ustilago mavdis. (In Russian.) Selsk. Choz. i. Lycsow 197:553-566.

75. DE CANDOLle, A. P. (DE LAMARCK, J. B., and DE CAxdolle, A. P.) 1815. Flore francaise 6. Paris.

76. DeCKenbaciI, K. N. 1925. A new parasite of smut fungi. La Délense des Piantes, Lenin. 2:162-165.

77. Delar, J. E. i954. Amino-acid composition of monosporidial cultures of Ustilago zeae of different sex. Phytopathology 44:583-587.

78. DeVaY, J. E., R. P. Cover, and P. N. NaIr. 1957 Corn diseases and their importance in Minnesota in 1956. Plant Disease Reptr. 41:505-507.

79. Dickinsox, S. 1926. A method of iso'ating and handling individual spores and tacteria. Proc. Royal Soc. Med. 19:1-4.

80. Dicksox, J. G., and D. H. Bowmsx. 1940. Inoculation experiments and reaction of inbred lines of corn to Ustiago zeae. Phytopathology 30:5.

81. Dorlayd, II. A. N. 18s7. Ustilago mardis, a study of the drug with reference to its employment as an oxytoxic. Med. News 51:534-536.

82. Dragisic, B., and B. VARICAK. 1935. Vergleichende Untersuchungen über die toxische llirkung des wässerigen Extrakts aus I'stilago maydis und der Mutterkornpreparate. Arch. Exptl. Pathol. Pharmakol. 179:319-326.

83. EdDixs, A. H. 1929. Pathogenicity of multispo- ridial and monosporidial cultures of Ustilago zeae (Beckm.) Ung. (Abstr.) Phytopathology 19:91.

84. Endixs, A. H. 1929. Pathogenicity and cultural behavior of Ustilago zeae (Beckm.) Ung. from different localities. Phytopathology 19:885-916.

85. Ehrlich, H. G. 1958. Nuclear behavior in mycelium of a solopathogenic line and in a cross of two haploid lines of Ustilago maydis (DC.) Cda. Mycologia 50:622 -627.

86. EldRedGe, J. C. 1935. The effect of injury in imitation of hail damage on the development of the corn plant. Iowa Agr. Expt. Sta. Bull. 185.

87. Exomoto, S. 1934. On the rest period and its shortening in smut spores (preliminary report). Trans. Sapporo Nat. Hist. Soc. 13:167-172.

88. Famixzix, A. 1912. Zur Erforschung der Wirkung von Tilletia tritici und Ustilago maydis auf den Menschen und Haustieren. Holl. Jahresb. 15:149.

89. Favret, E. A., A. P. Cercos, and A. Arila. 1954. Sustancia producida por Ustilago maydis con accion sobre el gluten. Rev. Invest. Agr. (Argentina ) 8:187-193

90. Felduan, A. IV. 1947. Studies on the physiological aspects of Ustilago zeae (Beckm.) Ung. Thesis, Univ. Minnesota.

91. Feldiax, A. IV. 1948. Investigations on the physiology and pathogenicity of Ustilago zeae. (Abstr.) Phy topathology 38:8

92. Feldmax, A. IV . 1948. Physiological effect of Ustilago zeae on corn. (Abstr.) Phytopathology 38:8-9.

93. Fersandez, M. I. 1952. Introduccion a la fitopatologia. 2nd ed. Gadola, Buenos Aires. 872 p.

94. FiCkE, C. H., and L. E. Melchers. 1929. The effect of the digestive processes of animals on the viability of corn and sorghum smut spores. J. Agr. Research 38:633-645.

95. Fischer, G. IV. 1936. The longevity of smut spores in herbarium specimens. Phytopathology 26:11181127.

96. Fischer, G. II. 1951. The smut fungi. Ronald Press Co., New York. 387 p.

97. Fischer, G. IV. 1953. Manual of the North American smut fungi. Ronald Press Co., New York. 343 p.

98. Fiscier, G. W., and C. S. Holtox. 1957. Biology and control of the smut fungi. Ronald Press Co., New York. 622 p.

99. Fisciler voN Waldheim, A. 1869-70. Beiträge zur Biologie und Entwickelungsgeschichte der Ustilagineen. Jahrb. Wiss. Botan. 7:61-144. (Transl. in New York State Agr. Soc. Trans. 30:280-354. 1872.)

100. Fletschmaxy, R. 1937. Einige Erfahrungen über Maisbrand in Ungarn. Pflanzenbau 14:199-206.

101. Freenax, E. M. 1905. Minnesota plant diseases. St. Paul, Minnesota. 432 p.

102. Frefias, E. M., and E. C. Stakmax. 1911. The smuts of grain crops. Minnesota Agr. Expt. Sta. Bull. 122:64.

103. Gamgee, J. 1871. Ill effects of smut in the feed of iarm animals. p. 73-81. In Rept. Com. Agr. on Diseases of Cattle in U.S. Washington.

104. Garber, R. J. 1931. Inbreeding with particular reference to maize. J. Am. Soc. Agron. 23:534-548

105. Garber, R. J., and M. M. Hooter. 1928. Influence of corn smut and hail damage on the yield of certain first-generation hybrids between synthetic varieties. J. Am. Soc. Agron. 20:38-45.

106. Garber, R. J., and M. M. Hoover. 1928. The relation of smut infection to yield in maize. J. Am. Soc. Agron. 20:735-746.

107. G.irber, R. J., and K. S. Quisexberry. 1925. Breeding corn for re istance to smut (Ustilago zeae). J. Am. Soc. Agron. 17:132-140.

108. GARCiA RADA, G. 1947. Fitopatologia agricola del Peru. Estacion Experimental Agricola de La Molina. Lima, Peru. 423 p.

109. Gaskix, T. A., and A. J. Ullestrup. 1958. An estimate of the incidence of corn smut and of the 
effects of the disease on yields in Indiana in 1957. Plant Disease Reptr. 42:374-375.

110. Gattani, M. L. 1946. Differences in diploid lines of Ustilago zeae. (Abstr.) Phytopathology 36:398.

111. Gattaxi, M. L. 1946. Studies on the behavior of diploid lines of Ustilago zeae (Beckm.) Ung. Thesis, Univ. Minnesota.

112. George, C. 18st. Ustilago maidis, Viburnum prunifolium, normal liquid Cannabis Indica. Therap. Gaz. X.S. 5:353.

113. Georgesox, C. C. 1891. Treating seed corn with creosote for smut. Kansas Agr. Expt. Sta. Bull. $30: 202-203$

114. GHeorghidior, I., and G. J. Fischer. 1952. El carbon del maiz; observaciones complementarias. Arch. Fitotecnico del Uruguay 5:119-129.

115. Gorf, E. S. 1894. Corn smut. Wisconsin Agr. Expt. Sta. Rept. 10:246-2+7

116. Goss, J. J. M. 1881. Ustilago maydis. Therap. Gaz. N.S. 2:51.

117. Griffiths, M. A. 1927. Smut resistance in corn. (Abstr.) Phytopathology 17:42.

118. Griffitus, M. A. 1928. Smut susceptibility of naturally resistant corn when artificially inoculated. J. Agr. Research 36:77-84.

119. GR ̈̈ss, J. 1902. Biologische Erscheinungen bei der Cultivierung von Ustilago mavdis. Ber. Deut. Botan. Ges. 20:212-220.

120. Güssow, H. T., and I. L. Coxiners, 1927. Studies in cereal diseases. 1. Smut diseases of cultivated plants and their control. Can. Dept. Agr. Bull. N.S. 81.79 p.

121. Нанх, J. H. 18s1. Ustilago maydis. Am. J. Pharm. 53:496.

122. Haxis, IV. F. 1928. A simple apparatus for isolating single spores. Phytopathology 18:1017-1021.

123. Haxxd, IV. F. 1929. Studies in the physiology and cytology of Ustilago zeae and Sorosporium reilianum. Phytopathology 19:415-441.

124. HARris, L. It. 1939. Allergy to grain dusts and smuts. J. Allergy 10:327-336.

125. HARRIS, L. H. 1939. The nature of the grain dust antigen. Crossed reactions to grain dusts and smuts. J. Allergy 10:433-442.

126. HAskixs, R. H. 1950. Biochemistry of the Ustilaginales. I. Preliminary cultural studies of Ustilago zeae. Can. J. Research C,28:213-223.

127. Haskixs, R. H., and J. A. ThorN. 1951. Biochemistry of the Ustilaginales. VII. Antibiotic activity of Ustilago acid. Can. J. Botany 29:585-592.

128. Hares, H. K., E. H. RiNke, and Y. S. TSIANG. 1946. Experimental study of convergent improvement and backcrossing in corn. Minnesota Agr. Expt. Sta. Tech. Bull. 172 .

129. HaYes, H. K., E. C. StakMax, F. Griffee, and J. J. Christexsex. 1924. Reactions of selfed lines of maize to Ustilago zeae. Phytopatho'ogy 14:268280.

130. Heald, F. D. 1926. Manual of plant diseases. McGraw-Hill Book Co., New York. 891 p.

1j1. Hexistg, E. 1901. On smut of corn and preventives against it. (In Swedish.) Landtmannen Linköpig, Manadsbilaga 1901:97-101.

132. HexrI, IT. A. 1881. Feeding corn smut. Univ. IVisconsin Board of Regents Ann. Rept. 1881: $50-54$

133. Hexry, IV. A. 1884. Corn smut. Wisconsin Agr. Expt. Sta. Rept. 1:25-27.

134. Hexry, II. A. 1888. Smut upon corn and timothy. Breeder's Gaz. 14:360-361.

135. Herrerd, A. L. 1875. Observaciones sobre los hongos comestibles. La Naturaleza 2:234-241.

136. HirschHorx, Eliss. 19.47. Critical observations on the Ustilaginacea. Farlowia 3:73-93.

137. Hirschiors, Elisa. 1951. Grado de estabilidad patógena de linéas monosporidiales de Ustilago zea adaptadas a desarroliar en medios que contienen arsénico. Ciencia Invest. (Argentina) 7:425426 .
138. HirschHORx, ElisA. 1953. Variaciones en Ustilago zeae. Ciencia Invet. (Argentina) 9:158-165.

139. HirschHors, Erisi, and J. Hirschilorx. 1935. Los carbones del Maiz en la Argentina. Caracteres sistematicos geneticos y parasitarios. Rec. Fac. Agron. La P'ata 20:108-139.

140. Hirschhorx, Elist, and J. Hirschiors. 1939. Accion del pH sobre los carácteres culturales del carbon del Maiz "Lstilago zeae" (Beck) Ung. Physis, Buenos Aires 18:223-251.

141. HirschHor., ElisA, and J. HirschHORx. 1939 Formas fisiologicas en "Ustilago zeae" de diversas localidades de la Argentina. Su caracterizacion geográfica. Physis, Buenos Aires 18:181-222.

142. Hirscilhers, Elist, and D. E. Muxiecke. 1950. The effect of sodium arsenite on the combining ability of monosporidial lines of Ustilago zeae. Phy'topathology 40:524-526.

143. Hitcheock, A. S., and J. B. S. Nortox. 1896 Corn smut. Kansas Agr. Expt. Sta. Bull. 62:169212.

144. Holliday, R. 1961. The genetics of Ustilago maydis. Genet. Research 2:204-230.

145. HollidaY, R. 1961. Induced mitotic crossing-over in Ustilago maydis. Genet. Research 2:231-248.

146. Holtox, C. S. 1941. Preliminary investigations on the dwarf bunt of wheat. Phytopathology 31:74 82.

147. Holtox, C. S. 1953. Physiologic specialization and genetics of the smut fungi. Botan. Rev. 19:187-208.

148. Hoorer, M. M. 1932. Inheritance studies of the reaction of selfed lines of maize to smut (Ustilago zeae). West Virginia Agr. Expt. Sta. Bull. 253: $1-32$.

149. Huxt, W. H., and M. R. Thompsox, 1938 . pharmacological study of Ustilago. J. Am. Pharmacol. Assoc. 27:740-752.

150. Hurd-Karrer, Axie M. 1926. Effect of smut on sap concentration in infected corn stalks. Am. J. Botany 13:286-290.

151. Hurd-Karrer, AxNie M., and H. Hasselbring. 1927. Effect of smut (Ustilago zeae) on the suga content of cornstalks. J. Agr. Research 34:191-195.

152. Hutchiss, H. L., and B. F. Lutarax. 1938. Spine development on the spores of Ustilago zeae. Phy topathology $28: 859-860$.

153. HüтTIG, IV. 1931. Über den Einfluss der Temperatur auf die Keimung und Geschlechtsverteilung bei Brandpilzen. Z. Botan. 24:529-557.

154. HürtIG, II. 1932. Die Grundagen zur Immunitätszüchtung gegen Brandpilze (Ustilagineen). (Sammelreferat) Der Züchter 4:209-219.

155. Iltis, H. 1910. Über eine durch Maisbrand verursachte intracarpellare Prolification bei Zea may's L. Sitzungsb. Akad WViss, Wien 119:331-34t.

156. InhoF, J. 1784. Zeae maydis morbus ad ustilaginem vulgo relatus. p. 1-36. Argentorati.

157. IMMER, F, R. 1927. The inheritance of reaction to Ustilago zeae in maize. Minnesota Agr. Expt. Sta. Tech. Bull. 51.

158. ImMer, F. R., and J. J. Christexsex. 1925. The reaction of selfed lines and crosses of maize to Ustilago zeae. Phytopathology 15:699-707.

159. IMMer, F. R., and J. J. Christensex. 1928. Influence of environmental factors on the seasonal prevalence of corn smut. Phytopathology 18:589598.

160. Immer, F. R., and J. J. Christexsex. 1928. Determination of losses due to smut infections in selfed lines of corn. Phytopathology 18:599-602.

161. Imarer, F. R., and J. J. Christensex, 1931. Further studies on reaction of corn to smut and effect of smut on vield. Phytopathology 21:661-674.

162. Itzerott, D. 1938. Über Keimung und IVachstum von Ustilago zeae (Beckm.) Ung. mit besonderer Berücksichtigung der Infektion. Phytopathol. Z. 11:155-180.

163. ItzerotT, D. 1938. Die Wirkung wuchsstoffhaltiger Substanzen junger Maispflanzen auf das Wachstum von Ustilago zeae. Arch. Mikrobiol 9:368-37t. 
164. Itzerott, D. 1939. Ein Fütterungsversuch an Meerschweinchen mit Maisbrandsporen. Z. Pflanzenkr. $49: 40-41$

165. Ivaxoff, B. 1926. Cryptogamic parasites of cultivated plants recorded in the course of the last five years (1921-1925). (In Bulgarian, German summary.) Agr. Inf. Period. Bull. Sofia $7: 14-17$.

166. JAckson, ElSA L., and J. B. Rowell. 1952. Mutation and environmental selection of growth types in Ustilago zeae. (Abstr.) Phytopathology 42:480.

167. JACKson, R. M. 1958. An investigation of fungistasis in Nigerian soils. J. Gen. Microbiol. 18:248258.

168. Jofinson, Delia E. 1931. The antibiosis of certain bacteria to smuts and some other fungi. Phytopathology 21:843-863.

169. Johrson, E. C. 1912. The smuts of wheat, cats barley, and corn. U.S.D.A. Farmers' Bull. 507. $32 \mathrm{p}$.

170. Johnson, I. J., and J. J. Christexsex. 1935. Relation between number, size, and location of smut infections to reduction in vie!d of corn. Phytopathology 25:223-233.

171. Johnsox, J. H. 1882. Notes on use of checken, Ustilago maidis and Berberris aquifolium. Therap. Gaz. N.S. 3:168.

172. Johnson, J. H. 1884. Ustilago maidis, cascara sagra, Jamaica dogwood, etc. Therap. Gaz. X.S $5: 16$.

173. JoNES, D. F. 1918. Segregation of susceptibility to parasitism in maize. Am. J. Botany 5:295-300.

174. JONES, D. F. 1920. Selection in self-fertilized lines as the basis for corn improvement. J. Am. Soc Agron. 12:77-100.

175. Jones, EDith S. 1923. Influence of temperature on the spore germination of U'stilago zeae. J. Agr. Research 24:593-597.

176. JORGENSON, L. R. 1929. Effect of smut infection on the yield of selfed lines and $F_{1}$ crosses in maize. J. Am. Soc. Agron. 21:1109-1112

177. KellermaN, W. A. 1891. Experiments with corn smut. Kansas Agr. Expt. Sta. Bull. 23:101-104.

178. KERNKAMP, M. F, 1938. The relative effect of genetic and environmental factors on growth types of Ustilago zeae. (Abstr.) Phytopathology 28:12.

179. KerNKAMP, M. F. 1939. Genetic and environmental factors affecting growth types of Ustilago zeae. Phytopathology 29:473-484.

180. Kerskamp, M. F. 1942. The relative effect of environment and genetic factors on growth types of Ustilago zeae. Phytopathology 32:554-567.

181. Kernkamp, M. F., and IT. J. Martin. 1941. The pathogenicity of paired haploid lines of Ustilago zeae versus the pathogenicity of numerous mixed haploids. Phytopathology 31:1051-1053.

182. Kernkamp, M. F., and M. A. Petty. 1941. Variation in the germination of chlamydospores of Ustilago zeae. Phytopathology 31:333-340.

183. KHARBUSH, S. S. 1928. Recherches histologiques sur les Ustilaginées. Rev. Pathol. Veg. et Entomol. Agr. 15:48-56.

184. Kxowles, E. L. 1889. A study of the abnormal structures induced by Ustilago zeae mays. J. Mycol. 5:14-18.

185. Koefler, B., and J. R. Holbert. 1938. Combating corn diseases in Illinois. Illinois Agr. Expt. Sta. Bull. 484.

186. KoMMEDAHL, T. 1954. Spore germination in Ustilago zeae as influenced by $\mathrm{KH}_{2} \mathrm{PO}_{4}$. Mycolc gia 46:151-156

187. Korsfeld, A. 1937. Behämpfung des Maisbeulenbrandes auf biologischer Grundlage. Z. PHanzenkr. $47: 277-297$

188. Kotte, IV. 1936. Pflanzenschutz im Maisbau. Kranke Pflanze 13:193-196.

189. K̈̈нх, J. 1858. Zur Entwickelungsgeschichte des Maisbrandes Ustilago maydis Tul. Hedwigia 2:5-7.

190. KÜH, J. 1859. Die Krankheiten der Kulturge- wachse, ihre Ursachen und ihre V'erhütung, Berlin. 312 p.

191. KüHx, J. 1866. Ustilago maydis. Z. Landw. Centralvereins d. Pr. Sachsen 1866:108.

192. Küнx, J. 1874. Ueber die Entwickelungsformen des Getreidebrandes und die Art des Eindringens der Keimfäden in die Nährpflanzen. Botan. Z 32:121-124.

193. KYLE, C. H. 1929. Relation of husk covering to smut of corn ears. U.S. Dept. Agr. Tech. Bull. 120:1-7.

194. Kyle, C. H. 1930. Relation between the vigor of the corn plant and its susceptibility to smut (Ustilago zeae). J. Agr. Research 41:221-231.

195. LAxDEx, E. IV. 1939. The spectral sensitivity of spores and sporidia of Ustilago zeae to monochromatic ultra-violet light. J. Cell. Comp. Physiol. $14: 217-226$

196. Leszczexko, P. 1926. On the influence of reaction of the medium on the germination of the spores of Verticillium albo-atrum R. et B. and Ustilago maydis Tul. (In Polish. English summary.) Mem. Inst. Natl. Polonais d'Econ. Rur. a Putawy $7(\mathrm{~A})$ : 402-435.

197. Leszczenko, P. 1928. Studies on the action of solutions of salts, alkalies, and acids on the spores of some pathogenic fungi. (In Polish, English summary.) (Transl. Phytopathol. Sect. in Pydgoszcz State Inst. Agr. Sci. 6.) 37 p.

198. Leveille, J. H. 1839. Recherches sur le developpement des Uredinees. Ann. Sci. Natl. Botany 2:1-16

199. Lerr, J., and S. B. Bogdaxovic. 19.34. Sur quelques proprietes pharmacodynamiques d'Ustilago maidis. Compt. Rend. Soc. Biol. Paris 116:590-592.

200. Link, G. K. K., H. W. Wilcox, and V. Eggers 1938. Growth tests with extracts of Erwinia amylovora, Phytomonas rhizogenes, T. deformans, and Ustilago zeae. (Abstr.) Phytopathology 28:15.

201. LiNk, H. E. 1809. Observationes in Ordines plantarum naturales. I. Magazin fur die neuesten Entdeckungen in der gesammten Naturkunde. Ges. Naturforschender Freunde zu Berlin 3:1-42.

202. LiskUN, E., and J. Krastavitsky. 1914. Effect of the spores of wheat and corn smuts (Tilletia tritici und Ustilago maydis) on animals. (In Russian.) Bull. Appl. Botany (St. Petersburg) 7(8):508-526.

203. Lu, S. I. 1952. A study of variation in black pigment production in Ustilago zeae (Beckm.) Unger. Thesis, Univ. Minnesota.

204. Lutman, B. F. 1910. Some contributions to the life history and cytology of the smuts. Trans. Wisconsin Acad. Sci. 16:1191-1244.

205. MacMillan, H. G. 1918. An epidemic of corn smut following hail. Phytopathology 8:584-585.

206. MadARlaGa, A. 1919. Plagas y enfermedades del Maiz. La Rev. Agr. 4:449-455.

207. Magee, C. J. 1954. Attempts to eradicate other plant diseases from Australia. Commonwealth Mycol. Conf. Rept. (London) 5:64-69.

208. Magnus, P. 1895. Seit wann ist der Maisbrand (Ustilago maydis (DC.) Tul.) in Deutschland? Deut. Botan. Monatschr. 13:49-53.

209. Maire, R. 1898. Note sur le developpement saprophytique et sur la structure cytologique des sporidies-levures chez Ustilago maydis. Bull. Soc. Mycol. France 14:161-173.

210. MarCHIS, E. DE. 1900. Richerche sull' Ustilago maydis. Bull. Royal Acad. Med. Roma 27:657-698.

211. Martinez, M. 1936. Plantas Utiles de la Republica Mexicana. Ediciones Botas, Mexico. $273 \mathrm{p}$.

212. Matsushima, T., and R. J. Klug. 1958. Utilization of L-sorbose by monosporidial lines and $\mathrm{mu}-$ tants of Ustilago maydis. Am. J. Botany 45:165168.

213. Mayerhofer, E., and B. Dragisic. 1938. Weiterer Bericht über kindliche Maisbrandvergiftungen (Ustilaginismus). Z. Kinderheilk. 59:543-552.

214. Maze, P., and P. J. Maze. 1932. Sur l'infection du mais par le charbon (Ustilago maidis). Compt. Rend. Soc. Biol. Paris 109:825-827. 
215. Maze, P., and P. J. MAZE. 1932. Influence des fumeurs organiques sur l'infection du maïs par I'Ustilago maidis. Compt. Rend. Soc. Biol. Paris $109: 835-837$.

216. Maze, P., and P. J. Maze. 1932. L'inegale resistance des varietes de Zea mais a l'infection du charbon (Ustilago maidis). Compt. Rend. Soc. Biol. Paris 109:1087-1088.

217. McAlpine, D. 1910. The smuts of Auctralia, their structure, life history, treatment, and classification. Melbourne, Australia. $288 \mathrm{p}$.

218. Melchers, L. E. 1916. Smuts of grain and forage crops in Kansas. Kansas Agr. Expt. Sta. Bull. 210.

219. Melciers, L. E. 1921. Ecologic and physiologic notes on corn smut, Ustilago zeae. (Abstr.) Phytopathology $11: 32$.

220. Melchers, L. E. 1925. Smut caused by Ustilago zeae (Beckm.) Ung. Plant Disease Reptr. Supp!. 40:161-164.

221. Melhus, I. E., and G. N. Davis, 1931. Nodal infection with the corn smut organism. (Abstr.) Phytopathology 21:129.

222. Melmus, I. E., and G. C. Kent. 1946. Pathology and mycology of corn. II. p. 60-64. Iowa Agr. Expt. Sta. Rept. 1944 1945.

223. Melmus, I. E., and G. Semeniuk. 1946. Pathology and mycology of corn. II. p. 49-52, Iowa Agr. Expt. Sta. Rept. $1945,1946$.

224. Menzies, J. D., and C. O. Stanberry. 1947. The effect of terminal smut galls on yield and seed grade of detasseled hybrid corn. Phytopathology $37: 363$.

225. Meyex, F. J. F. 1837. Ueber die Entwicklung des Getreidebrandes in dem Mays Pflanzen, Wien Arch. 3:419-421.

226. Meyen, F. J. F. 1841. Pflanzenpathologie. Lehre von dem kranken Leben und Bilden der Pflanzen, Berlin. 330 p.

227. Michaelson, M. E. 1957. Factors affecting development of stalk rot of corn caused by Diplodia zeae and Gibberella zeae. Phytopathology 47:499503.

228. MitcheL, J. 1886. The physiological action of Ustilago maidis on the nervous system. Therap. Gaz. Detroit 10:223-227.

229. MoORe, M. B. 1932. The genetics of Ustilago zeae. (Abstr.) Phytopathology 22:20.

230. Moore, M. B. 1936. A partial vacuum method for inoculating wheat and barley with loose smuts. Phytopathology 26:397-400.

231. Moore, R., W. O. Russell, and E. SACHS. 1946. Chronic leptomeningitis and ependymitis caused by ustilago, probably U. Zeae (corn smut). Am. J. Pathol. 22:761-778.

232. Moore, Y. A., and E. A. Schweinitz. 1896. Cornstalk disease and rabies in cattle. U.S. Dept. Agr. Bur. Animal Industry Bull. 10.

233. Moultox, J. E. 1942. Extraction of auxin from maize, from smut tumors of maize, and from Ustilago zeae. Botan. Gaz. 103:725-739.

234. Moulton, J. E., and G. K. K. Link. 1940. Auxin production by Ustilago zeae grown on a medium free of tryptophane. Phytopathology 30:17.

235. Muller, A. S. 1949. Corn diseases in Guatemala. (Spanish summary.) Iowa Agr. Expt. Sta. Research Bull. 371:597-602.

236. Muxnecke, D. E. 1948. An unusual host response to certain paired monosporidial cultures of Ustilago zeae. (Abstr.) Phytopathology 38:19.

237. Musuko, A. S., E. E. Geshele, and O. Y. Valter. 1960. Some questions of biology of causal agent of blister smut of maize. (In Russian.) Agrobiology, Moscow 4:579-582.

238. Nattrass, R. M. 1931. The smut disease of maize. Cyprus Agr. J. 26:81-82.

239. Nemec, B. 1932. Die Brandbeulen von Ustilago maydis. Studies Plant Physiol. Lab. Charles Univ., Prague 4:1-22.

240. Nemlienko, F. 1941. Ecological factors and blister smut of maize. (In Russian.) p. 39-41. C.R. PanSov. I.I. Lenin. Acad. Agr. Sci. Moscow.

241. Nifeneriauser, J. S. 1949. Enfermedades del maiz en Mexico. Oficina de Estudios Especiales, Secretaria de Agricultura y Ganaderia, Mexico, D.F., Folleto de Divul. 9.

242. Norton, J. B. S. 1896. A study of the Kansas Ustilagineae especially with regard to their germination. Trans. St. Louis Acad. Sci. 7:229-241.

243. Novoporrowski, I., and F. D. SKaskin. 1925. Effect of temperature on the germination of the chlamrdospores of cereal smuts (genus Ustilago). (In Russian.) Pam. N. Caucasus Regional Land Admin. Rostoff-on-Don. 28 p.

244. PaDr, S. M. 1957. Quantitative studies of fungus spores in the air. Mycologia 49:339-353.

245. PadF, S. M., and C. L. Kramer. 1960. Kansas aeromycology. VII. Smuts. Phytopathology 50:332334.

246. Pammel, L. H. 1892. Corn smut. Iowa Agr. Expt. Sta. Bull. 16:315-329.

247. Pammel, L. H. 1901. Corn smut. In grasses of Icwa. Iowa Geol. Survey Bull. 1:218-234.

248. Pammel, L. H. 1911. A manual of poisonous plants, chiefly of eastern North America, with brief notes on economic and medicinal plants and numerous illustrations. Cedar Rapids, Iowa. 214 p.

249. P.immel, L. H., and F. C. Stewart. 1893. Prevention of corn and oats smut. Iowa Agr. Expt. Sta. Bull. 20.

250. PARI, A. 1884. La Pellagra e l'Ustilago maydis. Italia Agr., Milan 16:328.

251. Parmentier, A. A. 1785. Le Mais ou ble de Turquie. Mem. Acad. Royal Sci. Bordeaux 1784: 31-35.

252. Parsons, H. B. 1882. Analyse von Ustilago maydis. U.S. Dept. Agr. Rept. 1880:136-138.

253. Pepper, B. B., and C. M. Haenseler. 1944. Control of European corn borer and ear smut on sweet corn with dusts and sprays. New Jersey Agr. Expt. Sta. Circ. 486.

254. Perkins, D. D. 1949. Biochemical mutants in the smut fungus, Ustilago maydis. Genetics 34:607-626.

255. Perlet, J. 1938. Zur Bekämpfung des MaisBeulenbrandes. Deut. Landw. Presse 65:7-8, 16.

256. Petty, M. A., JR. 1940. The effect of certain environmental factors on the phenotypic variability and genetic variation in Ustilago zeae (Beckm.) Unger. Thesis, Univ. Minnesota

257. Petty, M. A. 1942. Physical and chemical adaptation and environmental "carry over" effects in Ustilago zeae. (Abstr.) Phytopathology 32:14.

258. Pracco, R. 1933. Ipertrofia ed anomalie dell'inflorescenza maschile del Mais Causata dal carbone. Giorn. Risicolt 23:177-181.

259. Pichler, F., and A. WöBer. 1922. Bestrahlungsversuche mit ultraviolettem Licht, Röntgenstrahlen und Radium zur Bekämpiung von Pflanzenkrankheiten. Centralbl. fur Bakteriol. Abt. 2,57:319-327.

260. Piemeisel, F. J. 1914. Some facts of the life history of Ustilago zeae (Beckm.) Unger. (Abstr.) Phy topathology 4:411-412.

261. Piemeisel, F. J. 1917. Factors affecting the parasitism of Ustilago zeae. Phytopathology 7:294-307.

262. Platz, G. A. 1928. The relation of oxygen to the germination of the chlamydospores of Ustilago zeae (Beckm.) Unger. Iowa State Coll. J. Sci. $2: 137-143$

263. Platz, G. A. 1929. Some factors influencing the pathogenicity of Ustilago zeae (Beckm.) Unger. Iowa State Coll. J. Sci. 3:177-214.

264. Platz, G. A., L. IV. Durreli, and Mary F. Howe. 1927. Effect of carbon dioxide upon the germination of chlamydospores of Ustilago zeae (Beckm.) Unger. J. Agr. Research 34:137-147.

265. PlowRIGHT, C. B. 1889. A monograph of the British Uredineae and Ustilagineae. London. $348 \mathrm{p}$.

266. Potter, A. A., and L. E. Melchers. 1917. Ecological observations on Ustilago zeae. (Abstr.) Phytopathology 7:73-74. 
267. Potter, A. A., and L. E. Melchers. 1925. Study of the life history and ecologic relations of the smut of maize. J. Agr. Research 30:161-173.

268. Preinixger, T. 1937. Durch Maisbrand (Ustilago maydis) bedingte Dermatomykose. Arch. Derm. Syph., Berlin 176:108-113.

269. R.ADEMAKer, C. J., and J. L. Fischer. 1887. Ustilagine. J. Pharm. 18:156.

270. RANKER, E. R. 1930. Synthetic nutrient solutions for culturing Ustilago zeae. J. Agr. Research $41: 435-443$.

271. RANkER, E. R. 1930. The nature of smut resistance in certain selfed lines of corn as indicated by filtration studies. J. Agr. Research 41:613-619.

272. RAxisiger, R.. and E. Lerser. 1935. Saugkraft und Brandantälligkeit bei Mais. Landeskultur $2: 18 \mathrm{~T}-188$

RAwitscher, F, 1912. Beiträge zur Kenntnis der Ustilagineen. I. Z. Botan. 4:673-706.

274. Rawisscher, F. 1922. Beiträge zur Fenntnis von Ustilagineen. II. Z. Botan. 14:273-296.

275. R.AY, J. 1903. Etude biologique sur les parasitisme. Ustilago maydis. Compt. Rend. 86:567-570.

276. Reissek, S. 1847. Ueber die durch den Brand verursachten Missbildungen des Maises. Haidinger's Naturwissenschaftl. Ber., Wien 1:14i.

277. Rolitis, F. D. 1829. De l'ergot du Mais et de ses effects sur l'homme et les animaux. Acad. Sci. Paris.

278. Rowtel, J. B. 1952. Factors and results in partialvacuum inoculation of seedling corn with Ustilago zeae. (Abstr.) Phytopathology $42: 17$.

279. Rowell, J. B. 1955. Segregation of sex factors in a diploid line of Ustilago zeae induced by alpha radiation. Science 121:304-306.

280. Rowell, J. B. 1955. Functional role of compatibility tactors and an in vitro test for sexual compatibility with haploid lines of Ustilago zeae. Phytopathology 45:370-374.

281. Rowell, J. B., and J. E. DeVAY. 1953. Factors affecting the partial vacuum inoculation of seedling corn with Ustilago zeae. Phytopathology $43: 654-658$.

282. Roweil, J. B., and J. E. DeVAy. 1954. Genetics of Ustilago zeae in relation to basic problems of its pathogenicity. Phytopathology 44:356-362.

SABOE, L. C., and H. K. HAyes. 1941. Genetic studies of reactions to smut and of firing in maize by means of chromosomal trans!ocations. J. Am. Soc. Agron. 33:463-470.

284. Sampsox, Kathleex. 1939. Lite cycles of smut fungi. British Mycol. Soc. Trans. 23:1-23.

285. Sartoris, G. B. 1924. Studies in the life-history and physiology of certain smuts. Am. J. Botany $11: 617-647$.

286. Satterlee, J. 1884. Corn mixed with smut. Michican Board Agr. Rept. 1883:45.

287. Schaffit, E. 1926. Zum Stand der Trockenbeizfrage. Mitt. Deut. Landw. Ges, 41:361 374.

288. Schaffxit, E., and A. Volk. 1927. Über den Eintlüss der Ernährung auf die Empfänglichkeit der Pflanzen für Parasiten. I. Teil. Forschungen auf dem Gebiet der Pllanzenkrankheiten und der Immunität im Pflanzenreich. III. Gustav Fischer, Jena.

289. Schellexberg, H. C. 1911. Die Brandpilze der Schweiz. Beiträge zur Kryptogamenflora der Schweiz Bern 3:1-180.

290. Schint, C. G. 1940. Cultural and genetic studies on Ustilago zeae. Phytopathology- 30:381-390.

291. Schopfer, II. H., and S. BluMer. 1938. Les facteurs de croissance des especes du genre Ustilago. Compt. Rend. Acad. Sci. Paris 206:1141-1143.

292. Schultz, IV. 1937. Maisbeulenbrand (Ustilago zeae). Forschungsdienst 3:143-151.

293. Schweinitz, L. D. 1822. Srnopsis fungorum Carolinae superioris. Schriften d. Nat. Ges. Leipzig 1:71.

294. Schweritz, L. D. 1831. Synopsis of North American Boreali. Trans. Am. Philosoph. Soc. 4:290.
295. Scossirol, G. O. R. 1940. Ustilago maydis e a utarchia. Riv. Ital. Essenze 22:82-86.

296. Scurti, J. 1949. Azione a distoanza del micelio nelle neoformazioni da Ustilago maydis. Nuovo. Giorn. Botan. Ital. N.S. 56:740-741.

297. Scurti, J. 1950. Sulla istopathologia del mais parassitato dell' Ustilago maydis. Ann. Sper. Agr. N.S. $4: 827-855$.

298. Selby, A. D., and J. F. Hickifax. 1897. Corn smut. Ohio Agr. Expt. Sta. Bull. 78:92-96.

299. SEYFERT, R. 1927. Über Schnallenbildung im Paarkernmyzel der Brandpilze. Z. Botan. 19:577-601.

300. Serriour, A. B. 1888. Smut of Indian corn. U.S. Dept. Agr. Rept. 1887:380-389.

301. Sleuiler, H. O. 1932. Über Sexualität und Zy'tologie von Ustilago zeae (Beckm.) Unger. Z. Botan. 25:209-263.

302. Sмiтн, C. D. 1896. Feeding corn smut to dairy cows. Michigan Agr. Expt. Sta. Bull. 137.

303. Smith, F. L. 1936. The effect of corn smut on the yield of grain in the San Jeaquin Valley of California. J. Am. Soc. Agron. 28:257-265.

304. SpaldiNg, $\mathrm{V}$. M. 1881. Ustilago maydis and related species. Therap. Gaz. Detroit 5:121-125.

305. Stakiax, E. C. 1913. Spore germinations of cereal smuts. Minnesota Agr. Expt. Sta. Bull. 133.

306. Stakmax, E. C. 1928. Physiologic specialization in plant pathogenic fungi. Leopoldina (Amerikaband) $4: 263-289$.

307. Stakmax, E. C. 1936. The problem of specialization and variation in phytopathogenic fungi. Genetica 18:372-389.

308. Stakmax, E. C. 1937. Variation in Ustilago zeae. Science N.S. 85:58-59.

309. Stakiax, E. C. 1938. Plant disease fungi constantly evolving new types. Science 88:438-439.

310. Stakmin;, E. C. 1947. Plant diseases are shifty enemies. p. 235-279. In Science in progress, 5th Ser. Yale Univ: Press.

311. Stakmiax, E. C., and J. J. Christexsex. 1926. Physiologic specialization of Ustilago zeae and Puccinia sorghi and their relation to corn improvement. (Abstr.) Phytopathology 16:84.

312. Stakmin, E. C., and J. J. Christexsex. 1927. Heterothallism in Ustilago zeae. Phytopathology $17: 827-834$.

313. Stakmax, E. C., and J. J. Christexsex. 1953. Problems of variability in fungi. p. 35-62. In Plant diseases. U.S. Dept. Agr. Ybk.

314. Stakian, E. C., J. J. Christensex, C. J. Eide, and B. Petursox. 1929. Mutation and hybridization in Ustilago zeae. Minnestota Agr. Expt. Sta. Tech. Bull. 65:1-66.

315. Stakida, E. C., J. J. Christexsex, and IV. F. H.xxd. 1929. Mutation in Ustilago zeae. (Abstr.) Phytopathology 19:106.

316. Stakiax, E. C., J. M. D.aly, M. L. Gattaxi, and I. WAHL. 1948. Variation induced by uranium nitrate in corn smut and the cultivated mushroom. Science 108:554-555.

317. Stakmax, E. C., and J. G. Harrar. 1957. Principles of plant pathology. Ronald Press Co., New York. $581 \mathrm{p}$.

318. Stakmix, E. C., A. IV. Hexry, G. C. Currax, and IV. N. Christopher. 1923. Spores in the upper air. J. Agr. Research 24:599-607.

319. Stakidax, E. C., M. F. KerNkimp, T. H. King, and $\mathrm{W}$. J. Martix. 1943. Genetic factors for mutability and mutant characters in Ustilago zeae. Am. J. Botany 30:37-48.

320. Stakmax, E. C., M. F. Kerskimip, W. J. Martix, and T. H. KIxc. 1943. The inheritance of a white mutant character in Ustilago zeae. Phytopathology 33:943-949.

321. Stakmax, E. C., F. I'. Sterexson, and C. T. Wilson. 1946. Adaptation of monosporidial lines of Ustilago zeae to arsenic. (Abstr.) Phytopathology 36:411.

322. Stakmax, E. C., L. J. Trier, and G. E. Hafstad. 1933. The constance of cultural characters and 
pathogenicity in variant lines of Ustilago zeae. Bull. Torrey Botan. Club 60:565-572.

323. Stakmax, E. C., L. J. Tyler, G. E. Hafstad, and E. G. Shartelte. 1935. Experiments on physiologic specialization and nature of variation in Ustilago zeae. (Abstr.) Phytopathology 25:34.

324. Starr, G. H. 1933. A study of the diseases of canning crops (peas and corn) in Minnesota. Minnesota Agr. Expt. Sta. Tech. Bull. 89.

325. Stevess, K., I. E. Melhus, G. Semeniuk, and L. TIFFAxy. 1946. A new method of inoculating some Maydeae with Ustilago zeae (Beckm.) Unger. (Abstr.) Phytopathology 36:411.

326. Stevexson, J. A., and A. G. Johrson. 1944. The nomenclature of the cereal smut fungi. Plant Disease Reptr. 28:663-670.

327. Stewart, F. C. 1895. Effects of heat on the germination of corn and smut. Proc. Iowa Acad. Sci. $2: 74$.

328. Strixgfield, G. H., and D. H. Bowarax. 1942. Breeding corn hybrids for smut resistance. J. Am. Soc. Agron. 34:486-494.

329. StUART, II. 1896. Fungicides for the prevention of corn smut. Proc. Indiana Acad. Sci. 1895:96-99.

330. StUART, II. 1901. A study of the constituents of corn smut. Indiana Agr. Expt. Sta. Ann. Rept. 13:26-32.

331. TABExhaus, J. J. 1920. Diseases of grains, sorghums and millet, and their control in Texas. Texas Agr. Expt. Sta. Bull. 261.

332. TAPKE, V. F. 1948. Environment and the cereal smuts. Botan. Rev. 14:359-412.

333. Thorx, J. A., and R. H. Haskin. 1951. Biochemistry of the Ustilaginales. $\mathrm{V}$. Factors affecting the formation of Ustilagic acid by Ustilago zeae. Can. J. Botany 29:403-410.

334. Thuenax, F. vos, 1889. Zur Bekämpfung des Maisbrandes. Fühling's Landw. Z. 28:782.

335. Tillet, M. 1766. Observation sur la maladie du Mais ou ble de Turquie. Mem. Acad. Sci. Paris $1760: 254-261$

336. Tisdale, IV. H., and C. O. Johnston. 1926. A study of smut resistance in corn seedlings grown in the greenhouse. J. Agr. Research 32:649-668.

337. Tulasse, L. R., and C. Tulasse. 1847. Mémoire sur les Ustilaginées comparées aux Urédinées. Ann. Sci. Natl. Botany (Ser. 3) 7:12-127.

338. Turiax, G. 1960. Accumulation of 3-indole acetic acid and activation of enzymes in Ustilago induced tumor of maize. Proc. Conf. Sci. Problems of Plant Protection 1:35-39.

339. Uxger, F, 1833. Die Exantheme der Pflanzen. Wien. $422 \mathrm{p}$.

340. Uxger, F. 1836. Ueber den Einfluss des Bodens auf die Vertheilung der Gewächse, nachgewiesen in der Vegetation des nordostlichen Tirols. Wien. 367 p.

341. U.S. Dept. Agr. Plant Disease Reptr. Suppl. 40:162164. 1925; 87:20-26. 1935; 107:104-106. 1938; $127: 186-188.1940$.

342. VAGAS, E., and G. J. MAtcz. 1960. A quick method for staining the hyphae of Ustilago maydis. Stain Technol. 35:220-222.

343. Terplaxcke, G. 1930. Etude biometrique de quelques formes d'Ustilago zeae. Bull. Soc. Botan. Belgium 62:137-170.

344. Villeada, M. M. 1903. Hongos parasitos de las plantas cultivadas. La Naturaleza Segunda Ser. 3, Appendice p. 52.

345. VoнL, G. J. 1938. Mehrjährige Beobachtungen über den Einfluss äusserer Bedingungen auf den Befall des Maises mit Beulenbrand (Ustilago zeae). Pflanzenbau 14:465-480.
346. Volk, A. 1931. Beiträge zur Kenntnis der Wechselbeziehungen zwischen Kulturpflanzen, ihren Parasiten und der U'mwelt. Einflüsse des Bodens, der Luft, und des Lichtes auf die Empfänglichkeit der Pflanzen fur Krankheiten. Phytopathol. Z. $3: 1-88$.

347. Waldbott, G. L., and M. S. Ascher. 1940. Rust and smut, major causes of respiratory allergy. Ann. Internal Med. 14:215-224.

348. Wallix, J. R. 1949. A new method of inoculating the Maydeae with smut fungi. Science 109:312-313.

349. Wallroth, F. G. 1833. Flora cryptogamica germaniae. 4. Norenbergae. 923 p.

350. Walter, J. M. 1934. The mode of entrance of Ustilago zeae into corn. Phytopathology 24:1012-1020.

351. Walter, J. M. 1935. Factors affecting the development of corn smut, Ustilago zeae (Beckm.) Unger. Minnesota Agr. Expt. Sta. Tech. Bull. 111

352. Weiss, J. E. 1902. Der Maisbrand oder Beulenbrand des Mais (Ustilago maydis). Prakt. Bl. Pflanzenbau Pflanzenschutz 5:71-72.

353. Werth, E. 1913. Versuche über den Einflusss des Maisbrandes auf die Blütenund Fruchtbildung des Maises. Ber. Tät. Biol. Anst. f. Land- u. Forstw. 14:12-13

354. Western, J. H. 1936. The biology of the oat smuts. IV. The invasion of some susceptible and resistant oat varieties, including Markton, by selected biological species of smut (Ustilago arenae (Pers.) Jens. and Ustilago kolleri Wille). Ann. Appl. Biol. $23: 245-263$.

355. Whitehouse, H. L. K. 1951. A survey of heterothallism in the Ustilaginales. British Mycol. Soc. Trans. 34:340-355.

356. Wilcoxsox, R. D., and R. P. Covey. 1959. Relations of crop sequence to tassel smut of corn. Plant Disease Reptr. 43:1271.

357. Wilcoxson, R. D., and R. P. Covey. 1960. The relationships between corn plant populations and smut infection. Agron. J. 52:545.

358. Wilkixsox, R. E., and G. C. Kent, 1945. Some factors determining the infection of corn by Ustilago zeae (Beckm.) Unger. Iowa State Coll. J. Sci. 19:401-413.

359. Winter, G. 1884. Die Pilze Deutschlands, Oesterrecins und der Schweiz. p. 97. In Rabenhorst's Kryptogamenflora von Deutschland, Vol. 1, 2nd ed.

360. Wiтtich, F. II. 1939. Further observations on allergy to smuts. Journal-Lancet Minneapolis 59:382.

361. Wittich, F. W., and E. C. Stakmas. 1937. Case of respiratory allergy due to inhalation of grain smuts. J. Allergy 8:189-193.

362. Wolf, F. T. 1952. The production of indole acetic acid by Ustilago zeae, and its possible significance in tumor formation. Proc. Natl. Acad. Sci. U.S. 38: 106

363. WoLf, F. T. 1953. The utilization of carbon and nitrogen compounds by Ustilago zeae. Mycologia $45: 516-522$.

364. WolfF, R. 1873. Beitrag zur Kenntnis der Ustilagineen. Botan. Z. 31:657-661, 673-677, 689-694.

365. YasudA, A. 1894. On Ustilago maydis Lev. (In Japanese.) Tokyo Botan. Magazine 8:443-445.

366. Zellner, J. 1910. Zur Chemie der höheren Pilze. $\mathrm{V}$. Über den Maisbrand (Ustilago maydis Tulasne). p. 116-117. Anz. Kais. Akad. Wiss. Wien.

367. ZILLIG, H. 1932. Rerhe II: Ustilaginales (Brandpilze). p. 196-204. In Sorauer, Handbuch d. Pflanzenkrank. Vol. 3 , 5 th ed. 



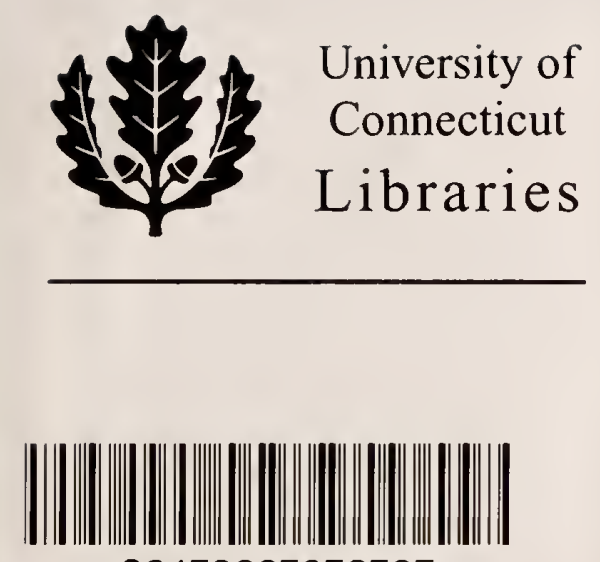
39153005658507 
